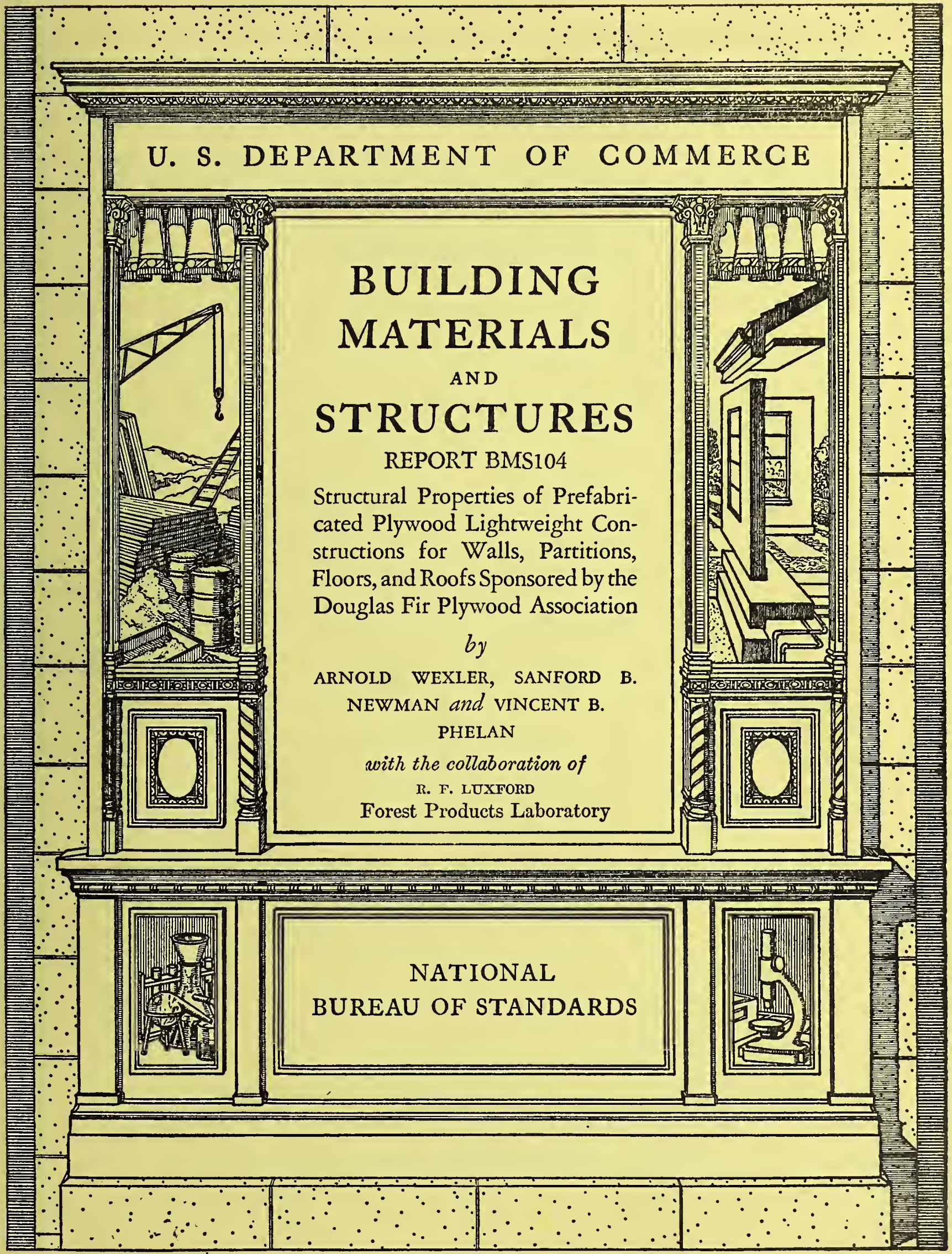




\section{BUILDING MATERIALS AND STRUCTURES REPORTS}

On request, the Superintendent of Documents, U. S. Government Printing Office, Washington 25 , D. C., will place your name on a special mailing list to receive notices of new reports in this series as soon as they are issued. There will be no charge for receiving such notices.

An alternative method is to deposit with the Superintendent of Documents the sum of $\$ 5$, with the request that the reports be sent to you as soon as issued, and that the cost thereof be charged against your deposit. This will provide for the mailing of the publications without delay. You will be notified when the amount of your deposit has become exhausted.

If 100 copies or more of any report are ordered at one time, a discount of 25 percent is allowed. Send all orders and remittances to the Superintendent of Documents, U. S. Government Printing Office, Washington 25, D. C.

The following publications in this series are available by purchase from the Superintendent of Documents at the prices indicated:

BMS1 Research on Building Materials and Structures for Use in Low-Cost Housing........ BMS2 Methods of Determining the Structural Properties of Low-Cost House Constructions... BMS3 Suitability of Fiber Insulating Lath as a Plaster Base $\ldots \ldots \ldots \ldots \ldots \ldots \ldots \ldots \ldots \ldots \ldots$

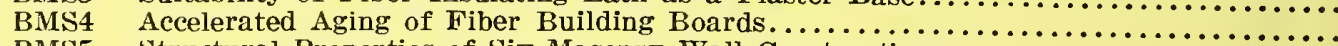

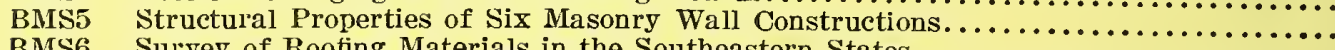

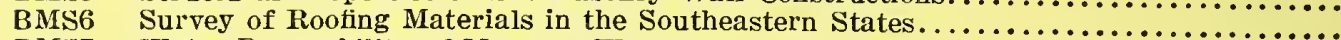

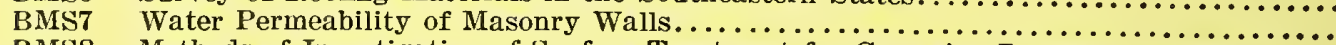

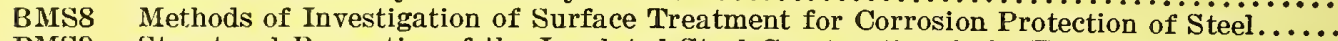

BMS9 Structural Properties of the Insulated Steel Construction Co.'s "Frameless Steel" Con-

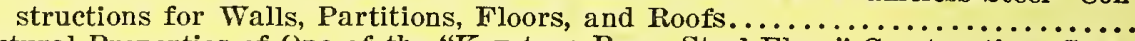

BMS10 Structural Properties of One of the "Keystone Beam Steel Floor" Constructions Spon-

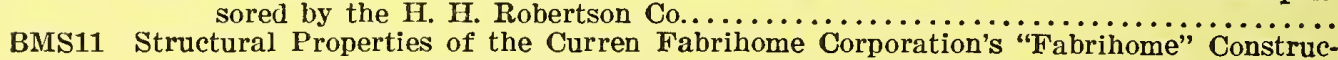

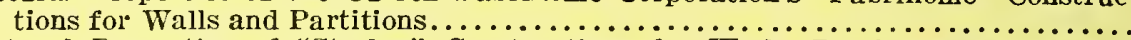

BMS12 Structural Properties of "Steelox" Constructions for Walls, Partitions, Floors, and

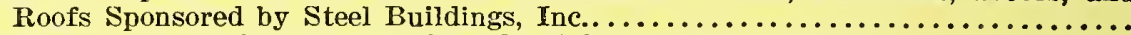

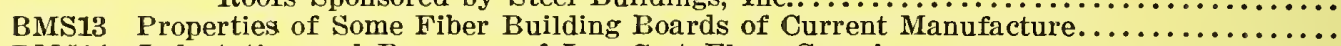

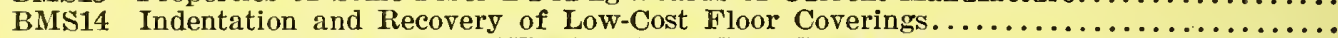

BMS15 Structural Properties of "Wheeling Long-Span Steel Floor" Construction Sponsored by

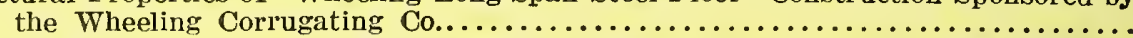

BMS16 Structural Properties of a "Tilecrete" Floor Construction Sponsored by Tilecrete

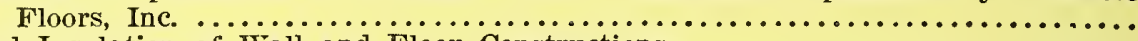

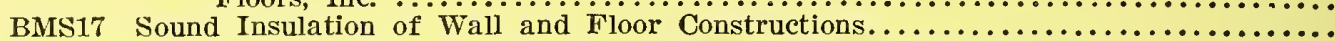

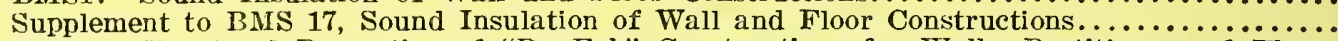

BMS18 Structural Properties of "Pre-Fab" Constructions for Walls, Partitions, and Floors

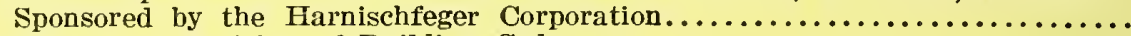

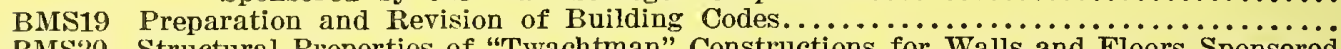

BMS20 Structural Properties of "Twachtman" Constructions for Walls and Floors Sponsored

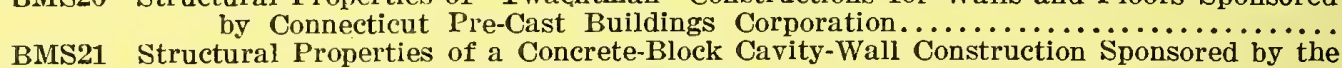

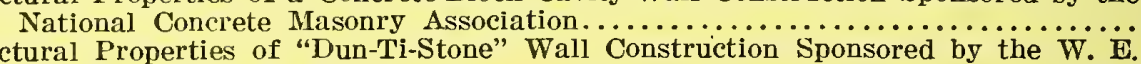

BMS22 Structural Properties of "Dun-Ti-Stone" Wall Construction Sponsored by the W. E.

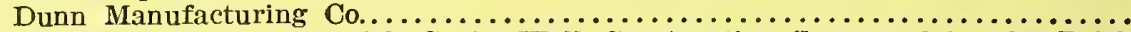

BMS23 Structural Properties of a Brick Cavity.Wall Construction Sponsored by the Brick

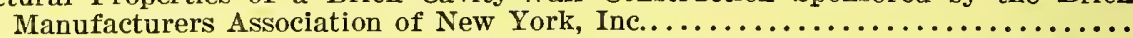

BMS24 Structural Properties of a Reinforced-Brick Wall Construction and a Brick-Tile CavityWall Construction Sponsored by the Structural Clay Products Institute........

BMS25 Structural Properties of Conventional Wood-Frame Constructions for Walls, Partitions,

BMS26 Structural Properties of "Nelson Pre-Cast Concrete Foundation" Wall Construction

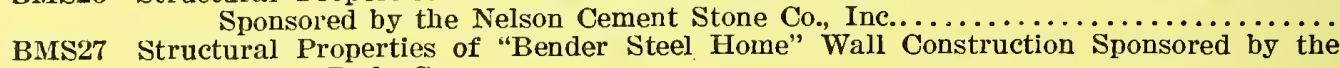

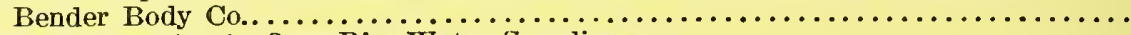

BMS28
BMS29
Surrey of Roofing Materials in the Northeastern States $_{\ldots} \ldots \ldots \ldots \ldots \ldots \ldots \ldots \ldots \ldots \ldots \ldots \ldots \ldots$

BMS30 Structural Properties of a Wood-Frame Wall Construction Sponsored by the Douglas

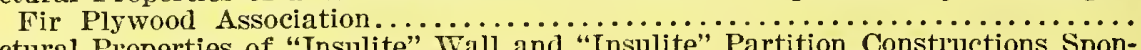

BMS31 Structural Properties of "Insulite" Wall and "Insulite" Partition Constiuctions Spon-

[List continued on cover page Irr]

* Out of print. 
UN I T D D T A T ES DEPART MENT OF COMMERCE . Henry A. Wallace, Secretary NA TI ONA L B UREAU OF S T A N A R D . Lyman .J. Briggs, Director

\section{BUILDING MATERIALS and STRUCTURES}

\section{REPOR T BMS104}

\section{Structural Properties of Prefabricated Plywood Lightweight Constructions for Walls, Partitions, Floors, and Roofs Sponsored by the Douglas Fir Plywood Association}

by ARNOLD WEXLER, SANFORD B. NEWMAN, and VINCENT B. PHELAN

with the collaboration of

R. F. LUXFORD

Forest Products Laboratory

Forest Service, United States Department of Agriculture

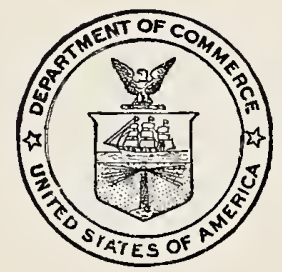

ISSUED NOVEMBER 1,1945

The National Bureau of Standards is a fact-finding organization; it does not "approve" any particular material or method of construction. The technical findings in this series of reports are to be construed accordingly 


\section{Foreword}

This report is one of a series issued by the National Bureau of Standards on the structural properties of constructions intended for low-cost houses and apartments. These constructions were originally sponsored by an organization within the building industry advocating and promoting their use and subsequently by the National Housing Agency seeking improvements in house constructions. The sponsor built and submitted the specimens described in this report for participation in the program outlined in Building Materials and Structures Report BMS2, Methods of Determining the Structural Properties of Low-Cost Itouse Constructions. The sponsor, therefore, is responsible for the design of the constructions and for the description of materials and method of fabrication. The Bureau is responsible for the testing of the specimens and preparation of the report.

This report covers the load-deformation relations and strength of the elements when subjected to compressive, transverse, concentrated. impact, and racking loads by standardized methods simulating the loads to which the elements would be subjected in actual service.

The National Bureau of Standards does not "approve" a construction nor does it express an opinion as to its merits for reasons given in reports BMS1 and BMS2. The technical facts presented in this series provide the basic data from which architects and engineers can determine whether a construction meets desired performance requirements.

Lrman J. B́riggs, Director. 


\title{
Structural Properties of Prefabricated Plywood Lightweight Constructions for Walls, Partitions, Floors, and Roofs Sponsored by the Douglas Fir Plywood Association
}

\author{
by ARNOLD WEXLER, SANFORD B. NEWMAN, and VINCENT B. PHELAN
}

with the collaboration of

li. F. LUXFORD

Forest Products Laboratory, Forest Fervice, United States Department of Agriculture

\section{O N T E N T S}

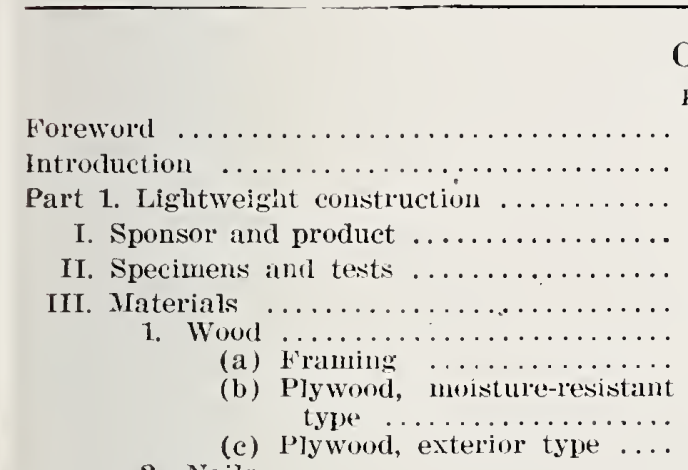

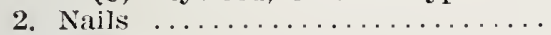

Page

IV. Wall $D V$

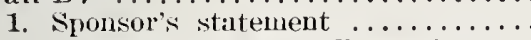

(a) Four-foot wall specimeus.

(b) Eight-foot wall specimens. .

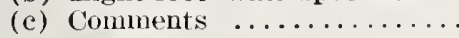

2. Compressive load $\ldots \ldots \ldots \ldots \ldots$.

3. Transverse load ..............

4. Concentrated load $\ldots \ldots \ldots \ldots \ldots$.

5. Impact load ...............

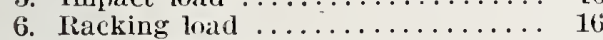

V. Partition $D W \ldots \ldots \ldots \ldots \ldots \ldots \ldots \ldots \ldots$

1. Sponsor's statement ......... 17

(a) Four-foot partition specimens $\ldots \ldots \ldots \ldots \ldots \ldots . \ldots \ldots$

(b) Eight-foot partition specimens .............. 18

(c) Comments ............ 18

2. Compressive load $\ldots \ldots \ldots \ldots \ldots \ldots$ 1s

3. Transverse load ............. 20

4. Concentrated Ioiad $\ldots \ldots \ldots \ldots \ldots \ldots$.

5. Impact load ................ 21

6. Racking load .............. 22

VI. Floor $D X$

1. Sponsor's statement ......... (a) Description of specimens ..

2. Transverse Ioarl ............

3. Concentrated loald $\ldots \ldots \ldots \ldots \ldots$.

4. Impact load .........................

VII. Floor $n \mathrm{Y} \ldots \ldots \ldots \ldots \ldots \ldots \ldots \ldots \ldots .24$

1. Sponsor's tittement ......... 24

(a) leseription of specimens . . 25

2 . Transver'se load ............. 26

3. Concentrated load $\ldots \ldots \ldots \ldots \ldots \ldots, 27$

4. Impact load ............... 27

VIII. Floor $n \Gamma a \ldots \ldots \ldots \ldots \ldots \ldots \ldots \ldots . . \ldots 29$

1. Sponsor's statement ......... 29

(a) Description of specimens .. 29

(b) Comments ........... 29

2. Transverse load ........... 29
Page

IX. IRof $D Z \ldots \ldots \ldots \ldots \ldots \ldots \ldots \ldots \ldots$

1. Sponser's statement $\ldots \ldots \ldots \ldots \ldots .30$ (a) loseriph of specimens .. 30

2 . Transverse load . . . . . . . . . . 31

3. Concentrated load .......... 31

X. Roof $D Z a \ldots \ldots \ldots \ldots \ldots \ldots \ldots \ldots \ldots$

1. Syonsor's statement ........ 32

(a) Deseription of syecimens . . 32

(b) Comments ........... 32

2. Transverse load .......... 33

XI. Additional comments by sponsor ..... 34

Part 2. Commercial type construction ...... 34

I. Sponsor and product .......... 34

11. Specinens and tests ........... 34

III. Materials ................ 35

1. Wood ................. 35

(a) Framing .........

(b) Plywood ............ 35

(r) Furring ........... 36

(d) Hevel siding $\ldots \ldots \ldots \ldots \ldots .36$

2. Sheathing papel ........... 36

3. Nails . . . . . . . . .

t. Staples ............... 36

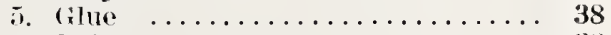

ti. Inint ................

1V. Wall $E A \ldots \ldots \ldots \ldots \ldots \ldots \ldots \ldots \ldots, 38$

1. Sponsor's statement ......... 38

(a) Four-fort wall specimens .. 38

(b) Eiglit-foot wall specinens. . 39

2. Laboratory statement ....... 40

3. Compressive loarl ............ 40

4. Transverse bat ........... 41

5. Concesitrated loarl ........... 42

(j. Imparet load ..............

7 . Racking load $\ldots \ldots \ldots \ldots \ldots \ldots \ldots$ 4

v. Wall $E A a \ldots \ldots \ldots \ldots \ldots \ldots \ldots \ldots \ldots$ \$5

1. Sponsor's statement .......... 45

(a) Description of specimens .. 45

2. Racking load ............. 45

VI. Wall $E A b \ldots \ldots \ldots \ldots \ldots \ldots \ldots \ldots \ldots \ldots$

1. Sponsor's statement ........ 45 (a) buscription of specimens .. 45

(b) Comments .......... 46

2. Racking load ............ 47

VII. Additional comments hy sponsor ..... 47 


\section{AINTRACT}

For the prosram on the determination of structural wroperties of low-cost house constructions, the loouslas Fir Plywood Association submitted 75 specimens representing plefabricated plywood building panels of both lightweight stress-skin and commercial design. Wall, partitiou, thoor, and boof specintens were of lightweight stress-skin design. Specintens of commercial type panels (2-by 4-in. studs) were for wall collstruction only, and fulnished a basis of (ompalisol of steength and weisht with the jight woight constructions.

The wall specimens were subjected to complessives. trallscess concentraterl, impact, and racking loads: and the wall specimens of commercial type included three different constructions for determining resistance to racking. The partition specimens were subjected to compressive, transverse. impact, and racking foads: the floor sperimens to transverse, concentrated, and impact loads: and the roof specineus to transverse and comcentrated loats. The floor and roof srecimens included two diflerent construetions for letermining resistance to transverse loads. Transvelse concentrated, and impact loads were applied to botl faces of wall surcimens. The loads simulated the loads to whicl the elements are subjected in actual sel'vice.

The deflection under load and the suts after the loal was removed wert* masuled for uniforni incroment of load. The losults ale presentere in waphs aud tables.

\section{INTRODLCTION}

To provide techuical facts on the performance of constructions for low-cost houses, to discover promising new constructions, and ultimately to determine the properties necessary for acceptable performance in actual service, the National Bureau of Standards has invited the cooperation of the building industry in a program of research on building materials and structures snitalile for low-cost louses and apartments. The objectives of this program are described in Building Materials and Structures Report BMS1, Research on Building Materials and Structures for Use in Low-Cost Housing.

To determine the strength of house constructions in the laboratory, standardized methods were dereloped for applying loads to portions of a completed house. Included in this study were masonry and wood constructions of types that have been used extensively for houses in this country. The reaction of these constructions under widely different service conditions is well known to builders and to the public. The B.IS Reports on these const rnctions are BMS5, Structural Properties of Six Masonry Wall Constructions, and BMS25, Structural Properties of Conventional WroodFrame Constructions for Tralls, Partitions, Floors, and Roofs. The masonry specimens were built by the Misonly Construction Section of this Bnrean, and the wood-frame specimens were built and tested by the Forest Produets Laboratory at Miadison, Tris.

The present report describes the structural properties of wall, partition, floor, and roof constructions sponsored by an association of manufacturer's in the building industry.

The wall specimens were tested for resistance to compressive, transverse, concentrated, impact, and racking loads simulating the loads to which the walls of a house are subjected. In actual service, compressive loads on a wall or load-bearing partition are produced by the veight of the roof, second floor and second story walls, if any, by furniture and occupants, and by snow and wind loads on the roof. Transverse loads are produced by wind: concentrated and impact loads by accidental contact with heavy objects: and racking loards by the action of the wind on adjoining walls.

Partition specimens were tested for resistance to compressive, transverse, impact, and racking loads. Canses of such loads on partitions are the same as for walls.

Floor specimens were tested for resistance to transverse, concentrated, and impact loads. Transverse loads are applied to floors by finrniture and occupants; concentrated loads by furniture. for example the legs of a piano; and impact loads by objects falling on the floor or by persons jumping on the floor.

Roof specimens were tested for resistance to transverse and concentrated loads. Transverse loads are applied to roofs by wind and snow; concentrated loads by persons walking on the roof, and by tools and equipment laid on the roof while it is being constructed or repaired.

The deflection and set under each increment of load were measured, because the suitability of a construction depends not only on its resistance to deformation when loads are applied but also on its ability to return to its original size and shape when the loads are removed. 


\section{PART 1. LIGHTWEIGHT CONSTRUCTION}

\section{SPONSOR AND PRODUCT}

The specimens were submitted by the Douglas Fir Plywood Association, Iacoma. Wash., and were built by the Evans Products Co., Marshfield, Ore., manufacturers of prefabricated houses employing Douglas fir plywood in their products. Each of the constructions consisted of a light weight wood frame and faces of Douglas fir plywood. The faces were securely ghed to the frames, so that each construction acted as a unit when resisting load. Buildings in which these constructions are used are designed to be erected on conventional masonry foundations. the panels joined by wood splines.

\section{SPECIMENS AND TESTS}

The specimens represented four elements of a house and were assigned the following symbols: Wall, $D \mathrm{~T}$; partition, $D W$; floor, specimens of 8-ft 0 -in. length, $D Y$; floor, specimens of $12-\mathrm{ft} 6-\mathrm{in}$. length and ceiling face buttjointed, $D Y$; floor. specimens of 12 -ft 6 -in. length and ceiling face scarf-jointed. $D Y a$; roof, specimens of 12 -ft 6 -in. length and ceiling face butt-jointed. $D Z$; roof. specimens of 12-ft 6 -in. length and ceiling face scarf-jointed, $D Z a$. The individual specimens were assigned the designations given in table 1 .

TABLE 1. Specimen designations

\begin{tabular}{|c|c|c|c|c|}
\hline Element & $\begin{array}{c}\text { Con- } \\
\text { struetion } \\
\text { symbol }\end{array}$ & $\begin{array}{c}\text { Specimen } \\
\text { designation }\end{array}$ & Load & $\begin{array}{l}\text { Load } \\
\text { applied }\end{array}$ \\
\hline 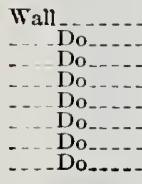 & $\begin{array}{l}D V \\
D V \\
D V \\
D V \\
D V \\
D V \\
D V^{Y} \\
D V^{V}\end{array}$ & $\begin{array}{l}C 1, C 2, C 3 \\
T 1, T 2, T 3 \\
T 4, T 5, T 6 \\
P 1, P 2, P 3 \\
P 4, P 5, P 6 \\
I 1, I 2, I 3 \\
I 4, I 5, I 6 \\
R 1, R 2, R 3\end{array}$ & $\begin{array}{l}\text { Compressive.. } \\
\text { Transverse } \\
\text { Concentrated } \\
\text { Impact } \\
\text { Racking }\end{array}$ & $\begin{array}{l}\text { Upper end. } \\
\text { Inside facc. } \\
\text { Outside face. } \\
\text { Inside face. } \\
\text { Outside face. } \\
\text { Inside facc. } \\
\text { Outside face. } \\
\text { Near upper cnd. }\end{array}$ \\
\hline 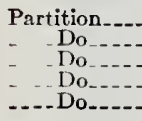 & $\begin{array}{l}D W \\
D W \\
D W \\
D W \\
D W\end{array}$ & $\begin{array}{l}C 1, C 2, C 3 \\
T 1, T 2, T 3 \\
P 1, P 2, P 3 \\
I 1, I 2, I 3 \\
R 1, R 2, R 3\end{array}$ & $\begin{array}{l}\text { Compressive }- \\
\text { Transverse } \\
\text { Concentrated } \\
\text { Impact } \\
\text { Racking }\end{array}$ & $\begin{array}{l}\text { Upper end. } \\
\text { Either face. } \\
\text { Do. } \\
\text { Do. } \\
\text { Near upper end. }\end{array}$ \\
\hline $\begin{array}{l}\ldots \\
\ldots \\
\ldots\end{array}$ & $\begin{array}{l}D X \\
D X \\
D X \\
D Y \\
D Y \\
D Y \\
D Y a\end{array}$ & $\begin{array}{l}T 1, T 2, T 3 \\
P 1, P 2, P 3 \\
I 1, T 2, I 3 \\
T 1, T 2, T 3 \\
P 1, P 2, P 3 \\
I 1, I 2, I 3 \\
T 1, T 2, T 3\end{array}$ & $\begin{array}{l}\text { Transverse } \\
\text { Concentrated } \\
\text { Impact } \\
\text { Transverseb } \\
\text { Concentrated - } \\
\text { Impact } \\
\text { Transverse }\end{array}$ & $\begin{array}{c}\text { Upper face. } \\
\text { Do. } \\
\text { Do. } \\
\text { Do. } \\
\text { Do. } \\
\text { Do. } \\
\text { Do. }\end{array}$ \\
\hline 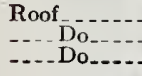 & $\begin{array}{l}D Z \\
D Z \\
D Z a\end{array}$ & $\begin{array}{l}T 1, T 2, T 3 \\
P 1, P 2, I 3 \\
T 1, T 2, T 3\end{array}$ & $\begin{array}{l}\text { Transverseb } \\
\text { Concentrated } \\
\text { Transverse - }\end{array}$ & $\begin{array}{l}\text { Do. } \\
\text { Do. } \\
\text { Do. }\end{array}$ \\
\hline
\end{tabular}

- The concentrated and impact loads were applied to the same specimens, impact loads first.

b The transverse and concentrated loads were applied to the same specimens, transverse loads first.

Specimens were tested in accordance with BMIS2 except where indicated to the contrary. That report also gives the requirements for the specimens and describes the results of tests by means of figures, particularly load-deformation graphs.

Because the shortening of the entire specimen under compressive load may not be proportional to the values obtained fiom compressometers attached to the specimen over only : portion of its height, the shortenings and the sets were measured with compressometers attached to the steel plate through which the load was applied, not attached to the specimen as described in BMi2.

The lateral deflections under compressive loads were measured with a deflectometer of fixed gage length, which consisted of a light (Duralumin) tubular frame having a leg at one end and a hinged plate at the other. The deflectometer in a vertical position was attached to the specimen by clamping the hinged plate near the upper end to one of the faces. The gage length (distance between the points of support) was $7 \mathrm{ft} 6$ in. 1 dial micrometer was mounted on the frame at midlength, with the spindle in contact with the wall or partition specimen. The dial was graduated to $0.001 \mathrm{in} .$, and the readings were recorded to the nearest division. There were two deflectometers on the specimen, one near each outer stud. This method of measurement was used instead of the taut-wire mirror scale method described in BMS2.

The indentation under concentrated load and the set after the load was removed were measured, not the set only, as described in BMS2. The apparatus is shown in figure 1.

The load was applied to the steel disk, $A$, to which the cross bar, $B$, was rigidly attached. The load was measured by means of the dynamometer, $C$. Two stands, $D$, rested on the face of the specimen, each supporting a dial micrometer, $E$, the spindle of which was in contact with the cross bar 8 in. from the center of the disk. The micrometers were graduated to $0.001 \mathrm{in}$., and readings were recorded to the nearest division. The initial reading (average of the micrometer readings) was observed under the initial load, which includerl the weight of the disk and dynamometer. I load was applied to the disk, and the average of these micrometer readings minus the initial reading was taken as the depth of the indentation under load.

The deflections and the sets under the impact load were measured by means of two deflectometers and two set gages, not one of each, as described in BMS2. The deflectometers were placed in contact with the unloaded face of the 
sperimen at molspan. ont moler each innes longitudinal member, and.the set gages rested on the loaded face, one orer each inner longitudinal nember. 'The readings, therefore, were not affected by local defonmations of the faces.

The deformations under racking loads were measured with a rigid angle deformeter consisting of a steel channel and a steel angle blaced to form a rigid connection. 'The channel of the deformeter rested on two steel plates, 4 by \pm in., $1 / 2$ in. thick, and was fastened to the top of the specimen by two nails extending into the top plate, the steel angle extending downward in the plane of the specimen. The bottom plate was in contact with the stop, to which a dial miclometer spindle was attached. The micrometer spindle was in contact with the steel angle of the deformeter. The gage length (distance from the top of the specimen to the spindle) was $7 \mathrm{ft} 113 / 4 \mathrm{in}$. The micrometer was graduated to $0.001 \mathrm{in.}$, and the readings were recorded to the nearest division. The deformeter was nsed instead of the taut-wire mirrorscale device described in BMS2.
Only three of the load-bearing partition specimens, $D \mathrm{H}^{*}$, were tested under the transverse, concentrated, and impact loads, not six specimens, as stated in BMS2. Inasmuch as the load-bearing partition construction was symmetrical about a plane midway between the faces, the results for these loads applied to one face of the specimens should be identical with those obtained by applying the loads to the other face.

The floor specimens, $D \mathrm{~T}$, were $8 \mathrm{ft}$ long, the length of commercial panels, and not $12 \mathrm{ft} 6 \mathrm{in}$. long as described in BMS2. The transverse and impact tests of the $D I$ specimens were, therefore, made on a span of $7 \mathrm{ft} 6 \mathrm{in}$.

The roof specimens, $D Z$, were $12 \mathrm{ft} 6 \mathrm{in}$. long. the length of commercial panels, and not $14 \mathrm{ft}$. 6 in. long as described in BMS2. The transverse tests of the $D Z$ specimens were, therefore, made on a span of $12 \mathrm{ft}$.

Because there was no reason to believe that the design of the splice in the lower plywood face would affect the concentrated load properties of the floor specimens, $D Y$, and because

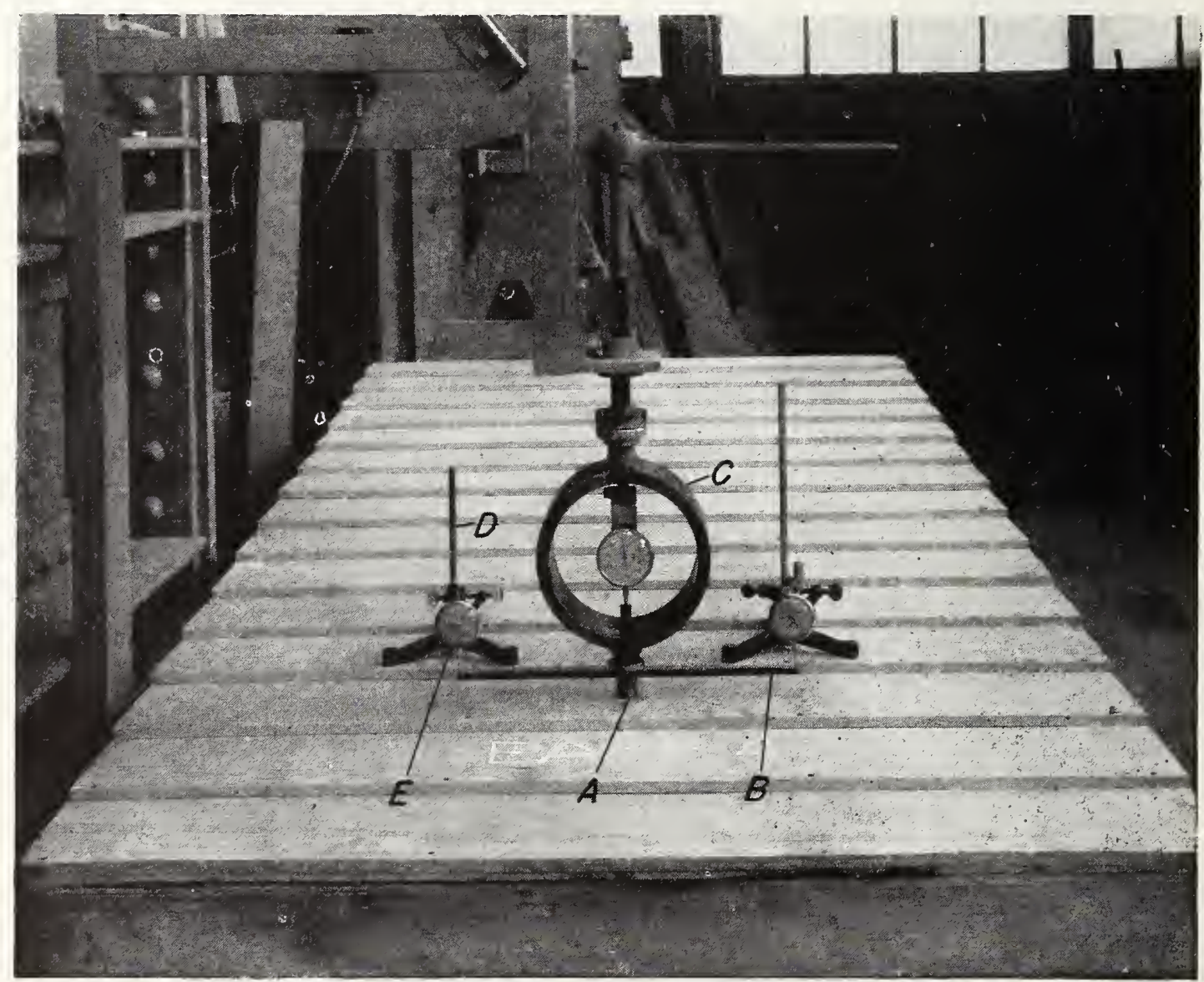

FIfURE 1.-Wall spccimen EA-P/ under concentrated load.

$A$, Steel loading disk; $l$. cross har: C. dynamometer; $D$, stand ; $E$, dial micrometer. 
they had not failed in the impact load test for a height-of-drop of $10 \mathrm{ft}$, the $D Y a$ specimens mere subjected only to transverse loads.

As it was improbable that the design of the splice in the lower plywood face would affect the concentrated load strength of the roof specimens $D Z$, the $D Z a$ specimens were subjected only to transverse loads.

The tests were begun May 24, 1943, and completed August 28, 1943. A stafi member of the Forest Products Laboratory witnessed the tests, and the sponsor's representative witnessed some of the tests.

\section{MATERIALS}

Information on the materials was obtained from the sponsor and by inspection of the specimens. The Forest Products Laboratory assisted by identifying the species of wood and the Engineering Mechanics Section of the $\mathrm{Na}$ tional Bureau of Standards assisted by determining the moisture content of the wood.

\section{Wo(1) \\ (a) Framing}

Although the sponsor stated that the framing was Douglas fir, No. 1, common, when the faces were removed it was observed that in the walls having 1 - by 3 -in. studs there were knots only in a very few of the specimens. 'These studs, therefore, were clear stock.

$$
\begin{aligned}
& 25 / 32 \text { by } 21 / 2 \text { in. (nominal } 1 \text { by } 3 \text { in.) } \\
& 25 / 32 \text { by } 31 / 2 \text { in. (nominal } 1 \text { by } 4 \text { in.) } \\
& 25 / 32 \text { by } 51 / 2 \text { in. (nominal } 1 \text { by } 6 \text { in.) } \\
& 11 / 2 \text { by } 21 / 2 \text { in. (nominal } 2 \text { by } 3 \text { in.) } \\
& 15 \% 8 \text { by } 15 \% 8 \text { in. (nominal } 2 \text { by } 2 \text { in.) } \\
& \text { (b) Plywood, Moisture-Resistant Type }
\end{aligned}
$$

Douglas fir, $1 / 4$-in., 3/8-in., and 1/2-in., bonded with water-resistant protein glue having a soya-bean and casein base. The $1 / 4$-in. plywood was 3 ply, wallboard grade, sanded, and complied with the requirements of Douglas Fir Plywood Association "Plywall." The 3/8-in.

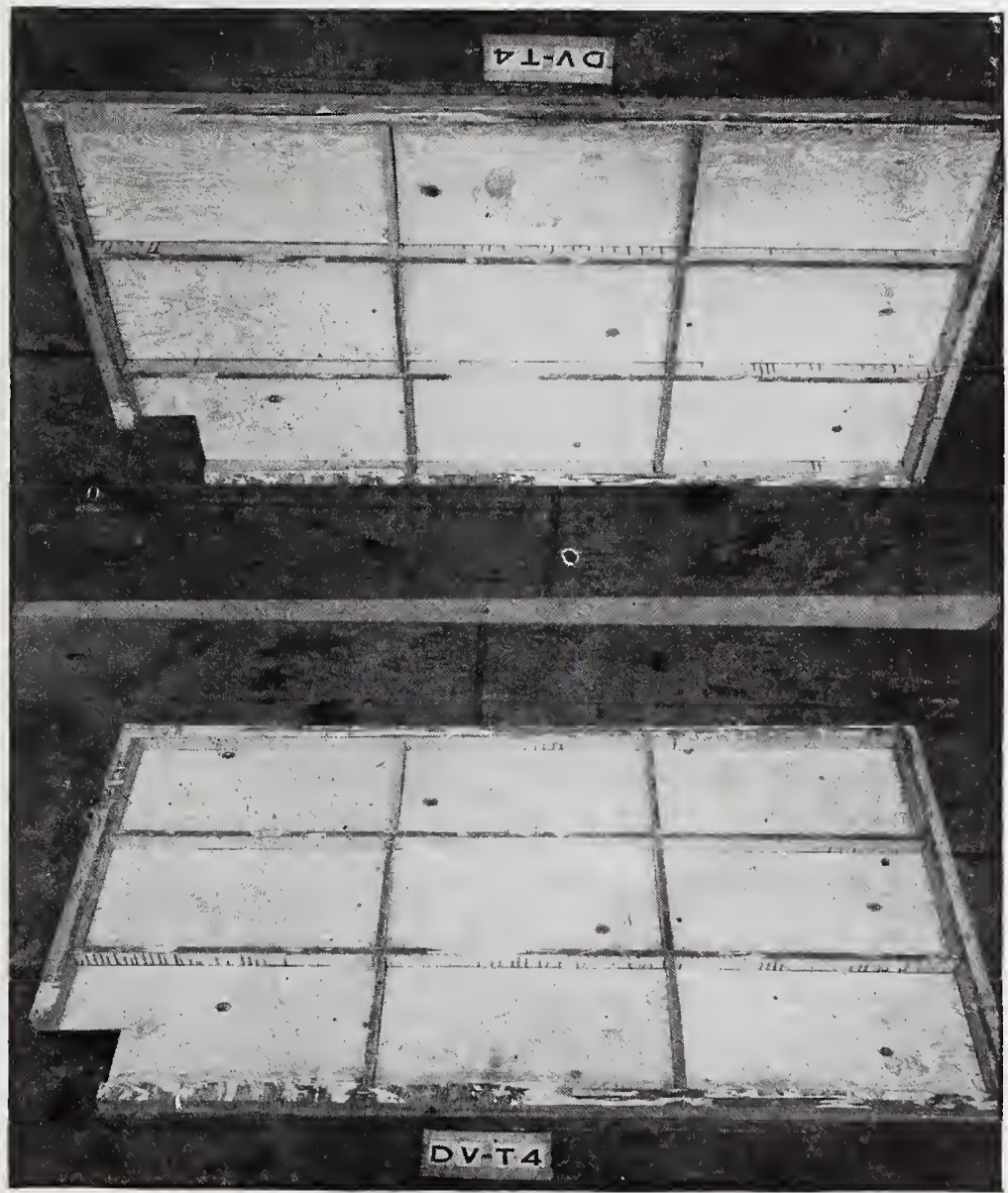

Figure 2.- Wall $D V$.

Typical 4-foot specimen. 


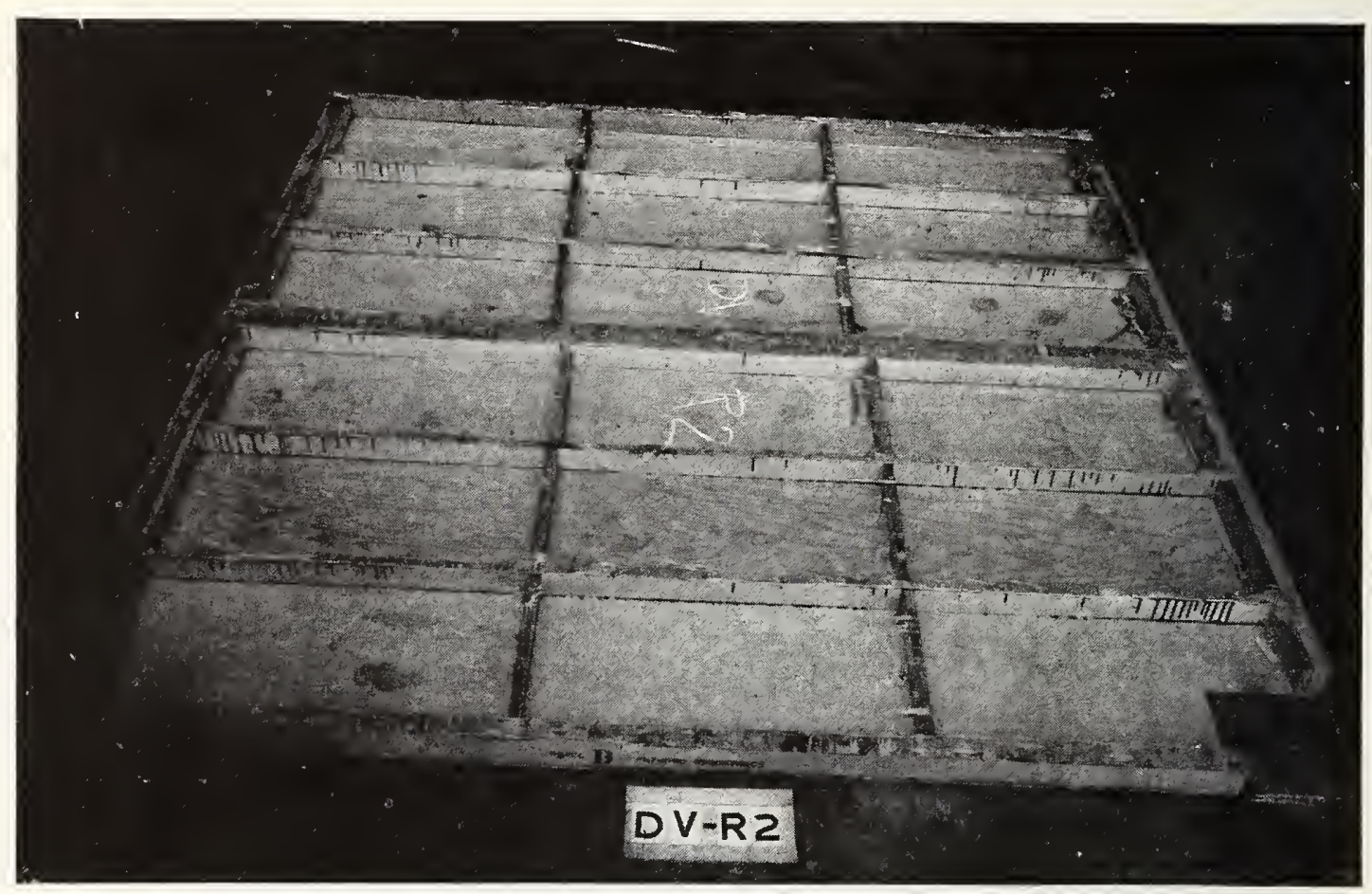

Figure 3-Wall $D V$.

Typical 8-foot specimen

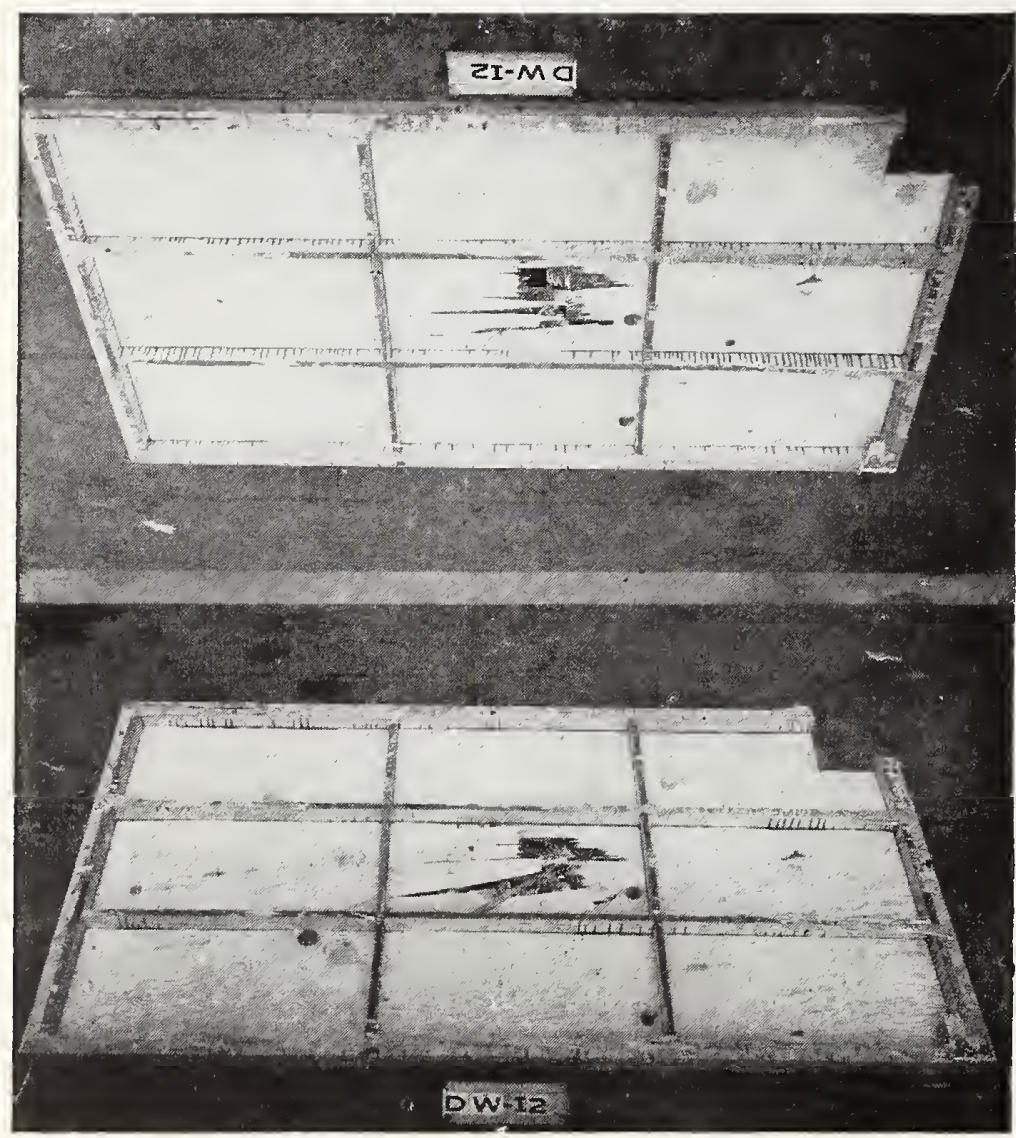

FIgURE 4.-Partition DW.

Typical 4-foot specimen.

[6] 
plywood was:3 ply sheathing grade, and comphed with Douglas Fir Plywood Issociation "Plyscord." The 1/2-in. plywood was 5 ply wallboard urade, sanded, and complied with Douglas Fir Plywood Association "Plywall." All plywood complied with Commercial Standard CS45-12.

\section{(c) Plywood, Exterior T'ype}

Douglas fir. 5/16-in. and 3/8-in., bonded with hot-press synt hetic-resin adhesive, 3 ply, grade S2S (sound two sides). The plywood complied with Commercial Standard CS+5-42 and was marked "Ext.-D.F.P.A."

After each specimen was tested, one face was removed to expose the framing, and samples of framing and plywood were cut for moisturecontent determination and for identification of the species. Fignres 2 to 8 , inclusive, are typical specimens.

Samples of plywood and framing were taken from each specimen on the day the specimen was tested; they were weighed and then dried to constant weight in an oven at $212^{\circ} \mathrm{F}$. The moisture content, given in table 2 , was calculated on the oven-dry weight.
TAHLE 2.-Morsture content of the wood

(1)etermined on the day the wall, partition, floor, or roof ejecimen was teated!

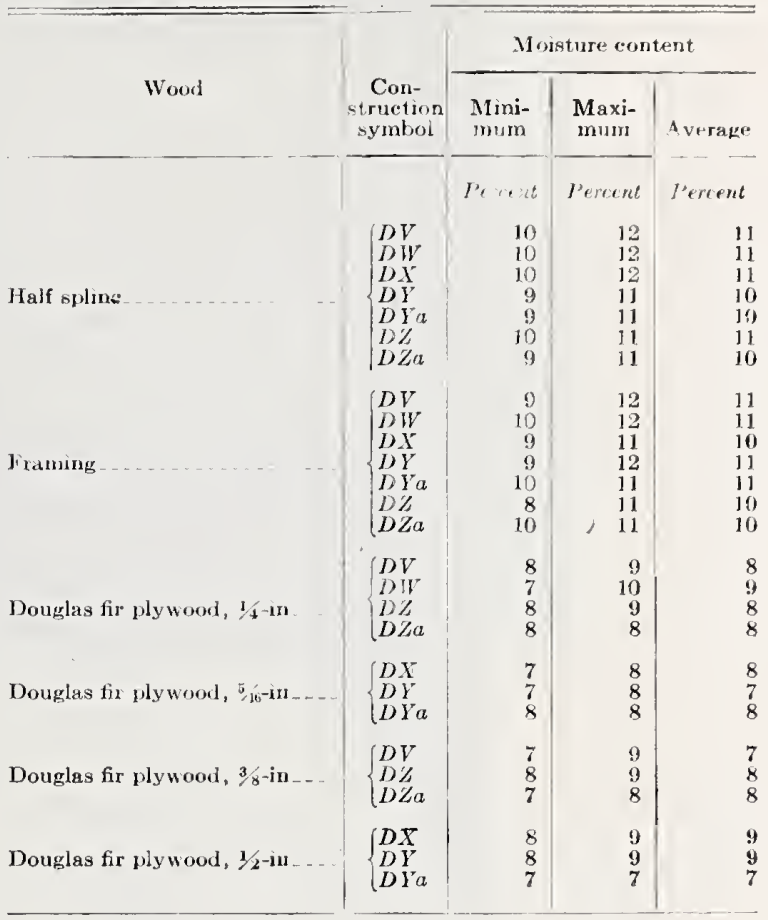

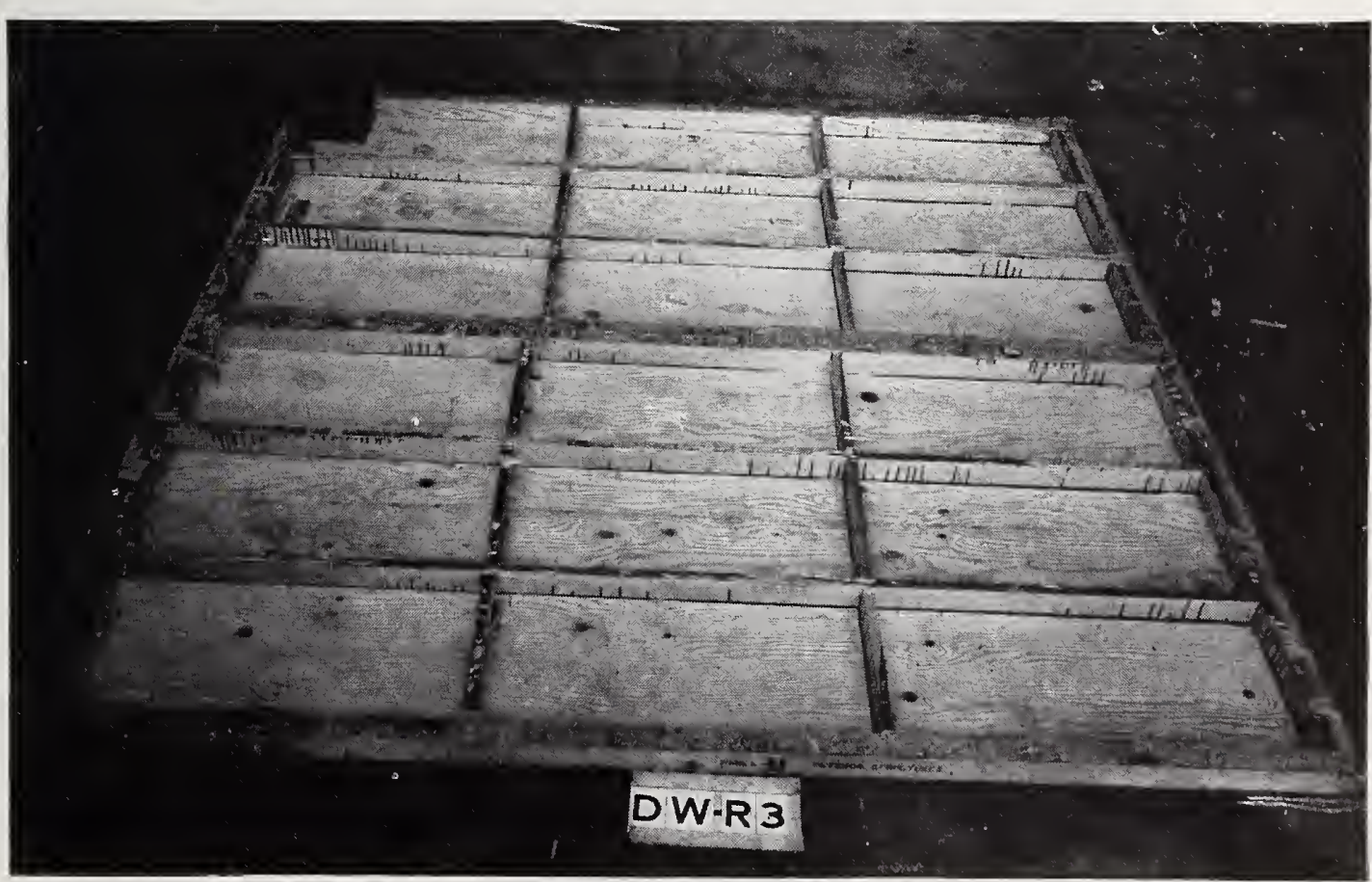

Figure 5-Partition $D W$.

Typical 8-foot specimen 


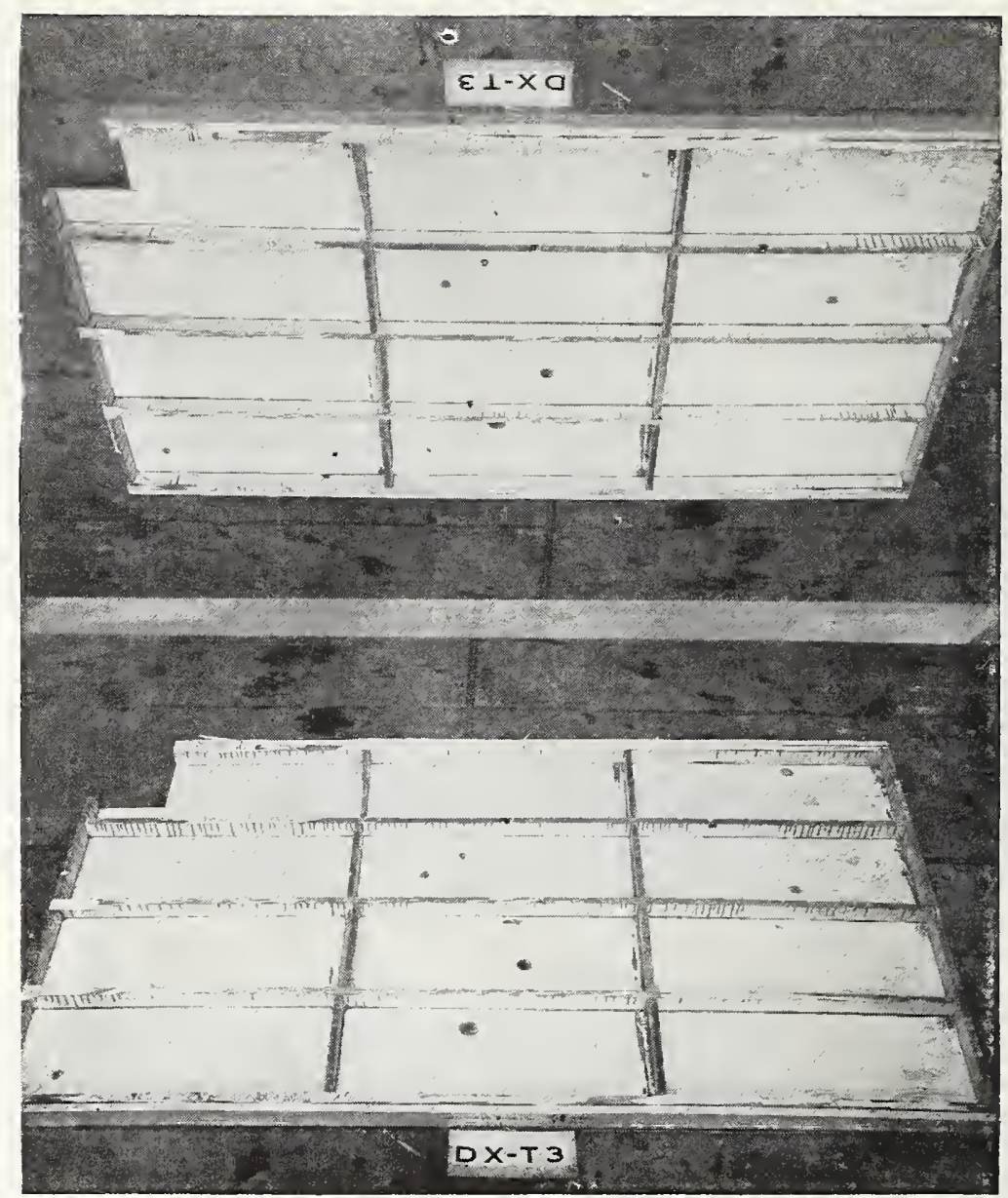

Figuthe (; FToOr ll

'ypical mpeciment.
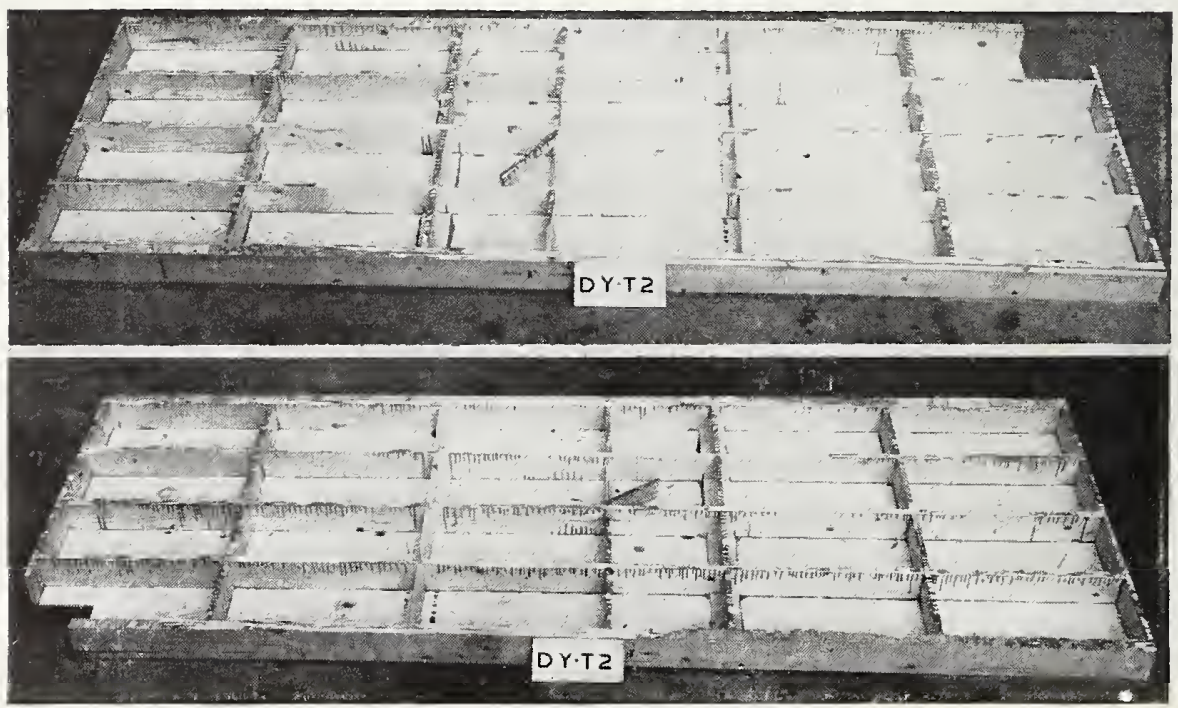

I'IGURE 7.-Floor $\mathrm{DY}$.

Trnical specimen 

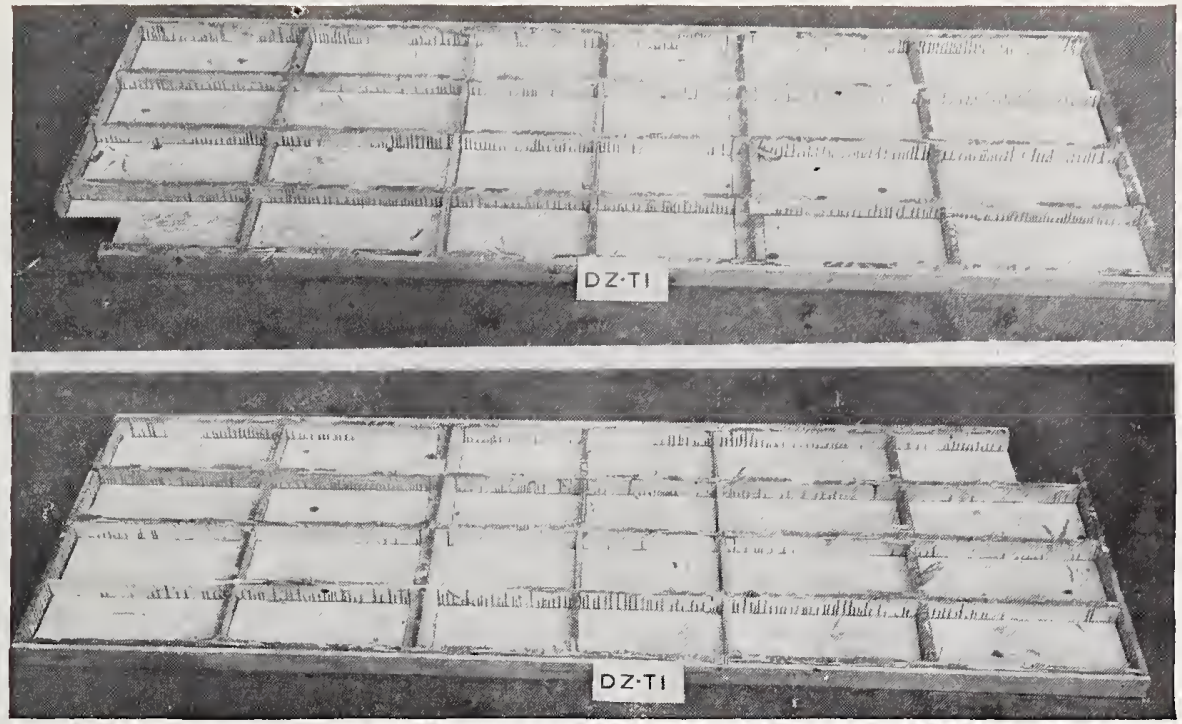

FIgURE 8.-Roof $D Z$.

Typical specimen.

\section{NaILS}

All nails were steel wire nails and are described in table 3 .

TABLE 3.-Description of nails

\begin{tabular}{|c|c|c|c|c|c|c|}
\hline Type & Size & Length & $\begin{array}{l}\text { Steel } \\
\text { wire } \\
\text { gage }\end{array}$ & $\begin{array}{l}\text { Diam- } \\
\text { eter }\end{array}$ & Finish & $\begin{array}{l}\text { Nails } \\
\text { per } \\
\text { pound }\end{array}$ \\
\hline & Penny & in. & No. & in. & & \\
\hline $\begin{array}{r}\text { Box } \\
\text { Do_- } \\
\text { Do.-- } \\
\text { Common- } \\
\text { Finishing- } \\
\text { Do... }\end{array}$ & $\begin{array}{r}83 \\
4 \\
6 \\
8 \\
3 \\
4\end{array}$ & $\begin{array}{l}11 / 4 \\
11 / 2 \\
2 \\
21 / 2 \\
11 / 4 \\
11 / 2\end{array}$ & $\begin{array}{l}141 / 2 \\
15 \\
121 / 2 \\
101 / 4 \\
151 / 2 \\
15\end{array}$ & $\begin{array}{c}0.076 \\
.072 \\
.0985 \\
.131 \\
.0673 \\
.072\end{array}$ & 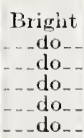 & $\begin{array}{l}c 35 \\
584 \\
23 j \\
106 \\
807 \\
581\end{array}$ \\
\hline
\end{tabular}

a Duckbill point.

\section{GLue}

Casein glue, grade $\Lambda$, ground. Formula : casein, 65 percent; lime, 15 percent; and dispersing agents and undisclosed ingredients, 20 percent. Eleven parts of glue were mixed with $211 / 4$ parts of water by weight. I. F. Laucks, Inc., "Lauxein 888."

\section{IVALL $D V$}

\section{SPonsor's Statement}

Wall $D V$ was a lightweight wood frame with plywood as both faces, the faces being fastened by glue. The faces were subjected to a pressure of $86 \mathrm{lb} / \mathrm{in}^{2}$ on surfaces of the frame for a period of 35 minutes, while the glue hardened. To hasten the time of set, the temperature of air surrounding work in the presses was raised to $141^{\circ} \mathrm{F}$ by panels of infrared light. The specimens were not painted.
The price of this construction in Washington, D. C., as of July 1937 was $\$ 0.24 / \mathrm{ft}^{2}$.

\section{(a) Four-Foot Wall Specimens}

The 4-ft wall specimens, shown in figure 9 , were $8 \mathrm{ft} 0 \mathrm{in}$. high, $3 \mathrm{ft} \mathrm{113/4}$ in. wide, and $31 / 8$ in. thick. Each was a wood frame to which the faces were fastened. 'The frame consisted of four studs, $A$, fastened to transverse members, $B$, at top and bottom. There were two lines of blocks, $C$, extending between the studs. Outside face, $D$, and inside face, $E$, each consisted of one piece of plywood. Plates, $F$, extended across the top and bottom ends of the specimens, and half splines, $G$, were inserted between the faces at the sides.

Studs.--The studs, $A$, were Douglas fir, $25 / 32$ by $2 \frac{1}{2}$ in. (nominal 1 by 3 in.) 7 ft $71 / 2$ in. long, spaced $1 \mathrm{ft} 3 \mathrm{in}$. on centers.

Transverse members.-The transverse members, $l$, were Douglas fir, $25 / 32$ by $21 / 2$ in. (nominal 1 by $3 \mathrm{in.}$ ) $3 \mathrm{ft} 101 / 4 \mathrm{in}$. long, extending across the ends of the studs. The transverse members were fastened to the studs by $6 \mathrm{~d}$ box nails driven through the transverse members into the ends of the studs, two nails into each stud end.

Blocks.-Blocks, $C$, were Douglas fir, $25 / 32$ by $2 \frac{1}{2}$ in. (nominal 1 by $3 \mathrm{in.)} 1 \mathrm{ft} 2 \frac{1}{4} \mathrm{in}$. long, inserted between the studs in two lines about equidistant from the transverse members and each other. The blocks were fastened to the studs by $6 \mathrm{~d}$ box nails. Two nails were 


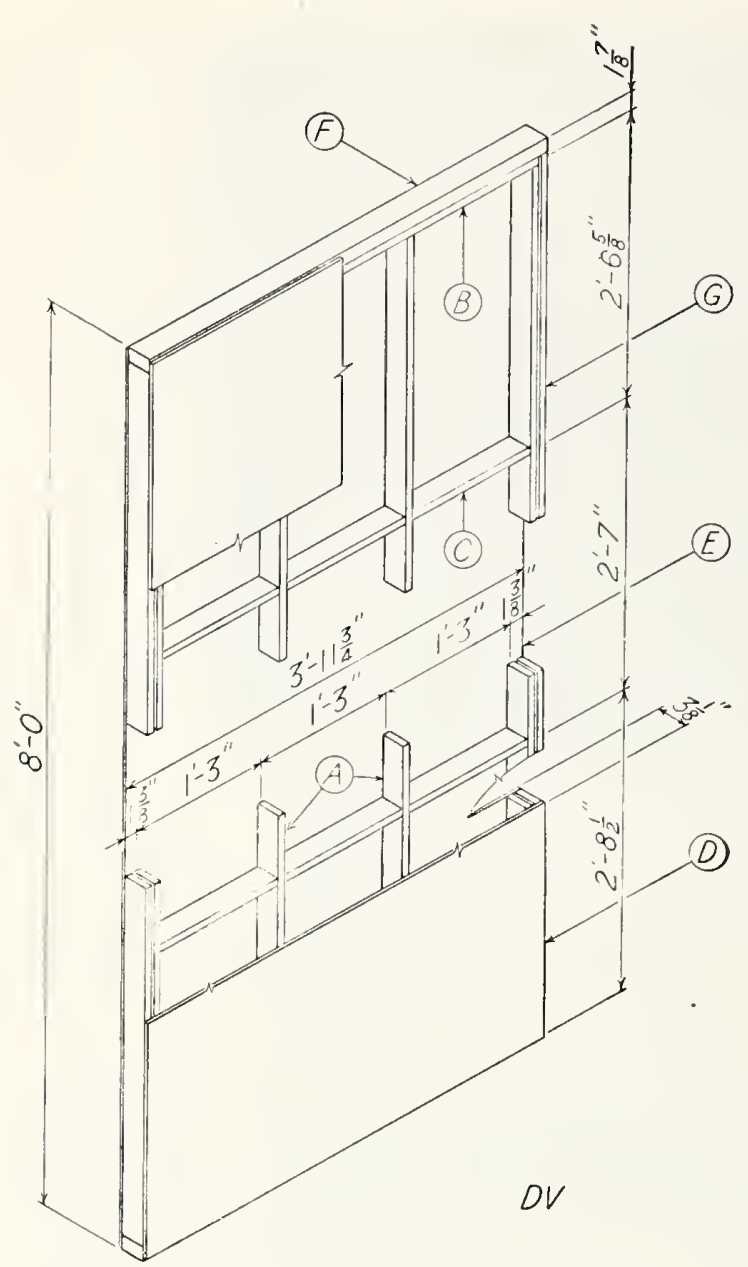

FiguRe 9.-Four-foot uall specimen $D V$.

A. Stud; $B$, transverse member; $C$, block; $D$, outside face; $E$, inside face; $F$, plate; $G$, half spline.

driven through the outer studs into the ends of the outer blocks and one nail through the jnner studs. The inner block was fastened by nails toenailed through the inner studs, one nail toenailed through each stud.

Outside face.-The outside face, $D$, was one piece of Douglas fir plywood, exterior type, $3 / 8$ $\mathrm{in}$. thick, $8 \mathrm{ft} 0 \mathrm{in}$. long, and $3 \mathrm{ft} 113 / 4 \mathrm{in}$. wide. It was fastened by ghe to all the frame members, which had been coated with the glue mixthire.

Inside face.-The inside face, $E$, was one piece of Douglas fir plywood, moisture-resistant type, $1 / 4$ in. thick, $8 \mathrm{ft} 0 \mathrm{in}$. long, and $3 \mathrm{ft}$ $113 / 4$ in. wide. It was fastened by glue to all the frame members, which had been coated with the glue mixture.
Plates.-Both floor and top plates, $F$, were Douglas fir, $11 / 2$ by $21 / 2$ in. (nominal 2 by 3 in.) $3 \mathrm{ft} .113 / 4$ in. long. The plates were inserted between the faces of the specimens after the faces had been attached to the frames and were fastened in place by $6 \mathrm{~d}$ box nails driven through the faces and spaced approximately 6 in. apart. There were also three $8 d$ common nails driven through each plate into the transverse member, spaced about halfway between the studs. In some specimens, glue had been partially applied to the sides of the plates, but in other cases this was omitted.

Half splines.-Half splines, $G$, were Douglas fir, $25 / 32$ by $21 / 2$ in. (nominal 1 by $3 \mathrm{in}$.) $7 \mathrm{ft}$ $9 \mathrm{in}$. long. The half splines were inserted between the faces of the specimens after the faces had been attached to the frames, and were fastened in place by 6d box nails driven through the faces and spaced approximately 6 in. apart. In some specimens, ghe had been partially applied to the sides of the half splines, but in other cases this was omitted.

\section{(b) Eight-Foot Trall specimens}

The 8-ft wall specimens, shown in figure 10 , were $8 \mathrm{ft} 0 \mathrm{in}$. high, $7 \mathrm{ft} 111 / 2 \mathrm{in}$. wide, and $31 / \mathrm{s}$ in. thick. The specimens consisted of two 4 -ft panels like the 4 -ft specimens, joined together and held in place by continuous plates, $F$, at top and bottom; and full size spline, $I I$, between the specimens.

Plates.-Plates, $F$, were similar to those for the 4 - $\mathrm{ft}$ specimens, but were $7 \mathrm{ft} 11 \frac{1}{2} \mathrm{z}$ in. loug, and fastened in a similar manner.

Spline.-Spline, $I I$, was Douglas fir, $1 \frac{1}{2}$ by $21 / 2$ in. (nominal 2 by $3 \mathrm{in}$.) $7 \mathrm{ft} 9 \mathrm{in}$. long. 'The spline was inserted between the faces of the adjoining panels, and the panels fiastened by $6 \mathrm{~d}$ box nails driven throngh the faces into the spline along the adjacent edges, spaced approximately $6 \mathrm{in}$. apart.

\section{(c) Comments}

The outside walls of a house consist of panels similar to the 4 - $\mathrm{ft}$ specimens. The panels rest on the floor, and are joined together and held in place by continuous plates at top and bottom and full-size wood splines between them as represented by the construction of the 8 - $\mathrm{ft}$ specimens. Openings for doors and windows are provided by specially constructed panels. The outside and inside surfaces of this construction are usually finished with paint. 


\section{Compressive Load}

Trall specimen $I) T^{2}-C I$, under compressive load, is shown in figure 11. The test results for wall specimens $D T-C 1, C \cdot 3$, and $C \cdot \dot{\prime}$, are shown in table 4 and figures 12 and 13 . The compressive loads were applied $1.02 \mathrm{in}$. (one-third the thickness of the panel) from the inside face of the panel.

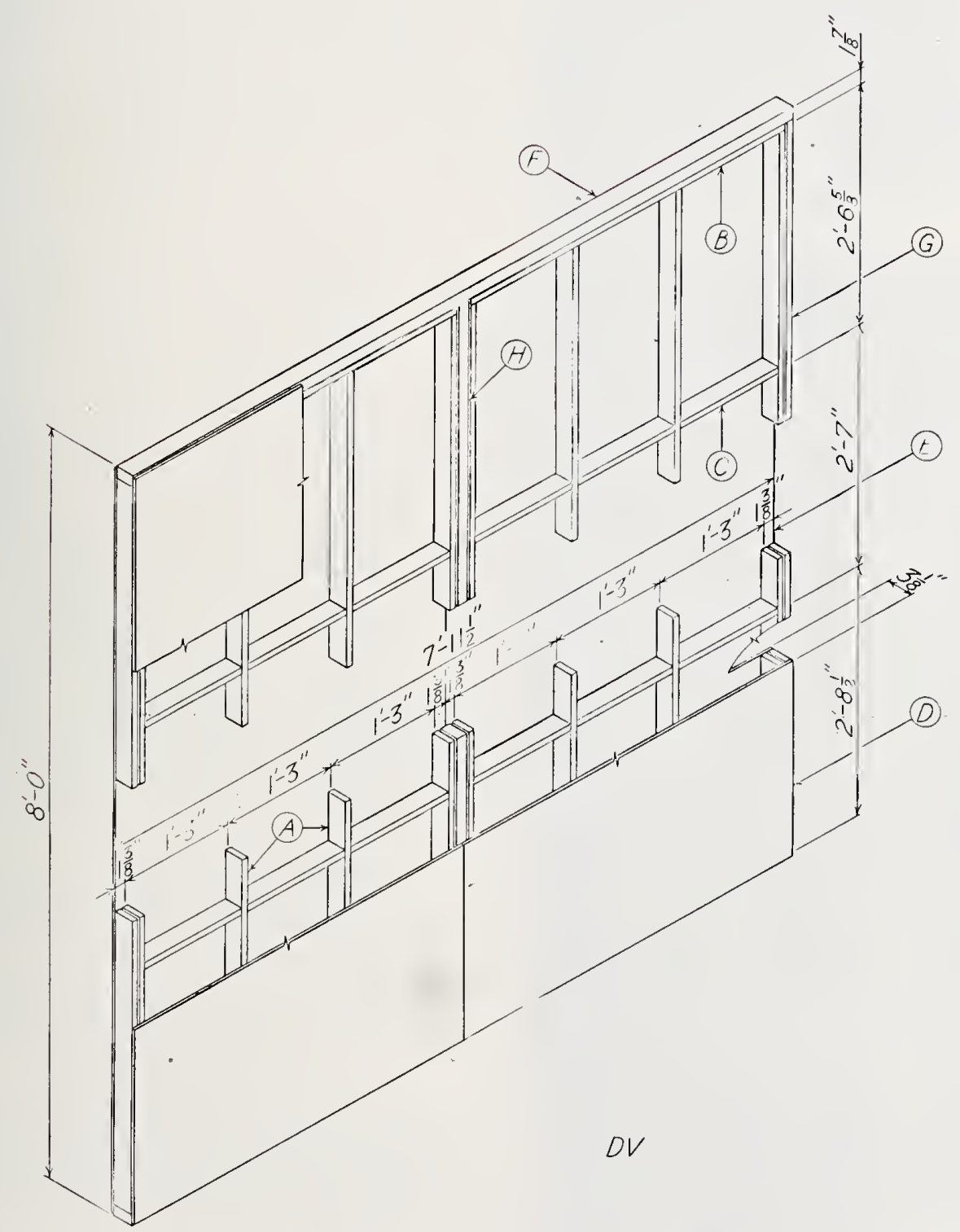

FIGUme 10.- Eight-foot wall spccim(n 1)V.

$A$, Stud; $B$, transverse member; $C$, block; $D$, outside face; $E$. Inside face; $F$, prate: $G$, half spline; $I I$, spline. 


\begin{tabular}{|c|c|c|c|c|c|c|c|c|c|}
\hline \multicolumn{2}{|c|}{ Compressive loada } & \multicolumn{2}{|c|}{$\begin{array}{c}\text { Transverse load; span, } \\
7 \mathrm{ft} 6 \text { il.. }\end{array}$} & \multicolumn{2}{|c|}{$\begin{array}{c}\text { Concentrated load; disk, } \\
\text { diam I in. }\end{array}$} & \multicolumn{2}{|c|}{$\begin{array}{l}\text { Impact load; span, } \\
7 \text { ft } 6 \text { in.; sandbag, } 60 \mathrm{lb}\end{array}$} & \multicolumn{2}{|c|}{ Racking İoad } \\
\hline Specimen & $\underset{\text { load }}{\text { Maximum }}$ & Specimen & $\underset{\text { load }}{\text { Maximum }}$ & Specimen & $\begin{array}{l}\text { Maximum } \\
\text { load }\end{array}$ & Specimen & $\underset{\text { load }}{\text { Maximum }}$ & Specimen & $\underset{\text { load }}{\text { Maximum }}$ \\
\hline $\begin{array}{l}C 1 \\
C 2 \\
C s_{-}\end{array}$ & $\begin{array}{r}\text { Kips/flu } \\
8.26 \\
10.87 \\
12.58\end{array}$ & $\begin{array}{l}T 1-\ldots \\
T 2-\cdots \\
T S_{-}\end{array}$ & $\begin{array}{r}l b / f t^{3} \\
257 \\
284 \\
309\end{array}$ & $\begin{array}{l}P 1 \\
P 2 \\
P 3\end{array}$ & $\begin{array}{r}l b \\
700 \\
655 \\
500\end{array}$ & $\begin{array}{l}I 1 \ldots \\
I 2 \ldots \\
I 3\end{array}$ & $\begin{array}{r}f t \\
7.5 \\
7.0 \\
8.0\end{array}$ & $\begin{array}{l}R 1-\ldots \\
R 2 \\
R 3-\end{array}$ & $\begin{array}{r}\text { Kips/ftb } \\
1.83 \\
2.35 \\
1.43\end{array}$ \\
\hline \multirow[t]{3}{*}{ Average } & $10 .-7$ & Average & 283 & Average & 618 & Average & 7.5 & Average & 1.87 \\
\hline & & $\begin{array}{l}T 4 \ldots \\
T 5 \\
T 6\end{array}$ & $\begin{array}{l}309 \\
268 \\
329\end{array}$ & $\begin{array}{l}P 4 \\
P 4 \\
1\end{array}$ & $\begin{array}{r}c 1,000 \\
885 \\
900\end{array}$ & $\begin{array}{l}I_{4} \\
I_{5} \ldots \ldots \\
I 6 \ldots\end{array}$ & $\begin{array}{l}c 10.0 \\
c 10.0 \\
c 10.0\end{array}$ & & \\
\hline & & tverage & 302 & Average & $\ldots$ & Average & 10.0 & & \\
\hline
\end{tabular}

- Load applied $1.02 \mathrm{in.}(\mathrm{I} / 3$ the thickness of the panel) from the inside face.

A lip is 1.000 lb.

- Test discontinued. No failure.

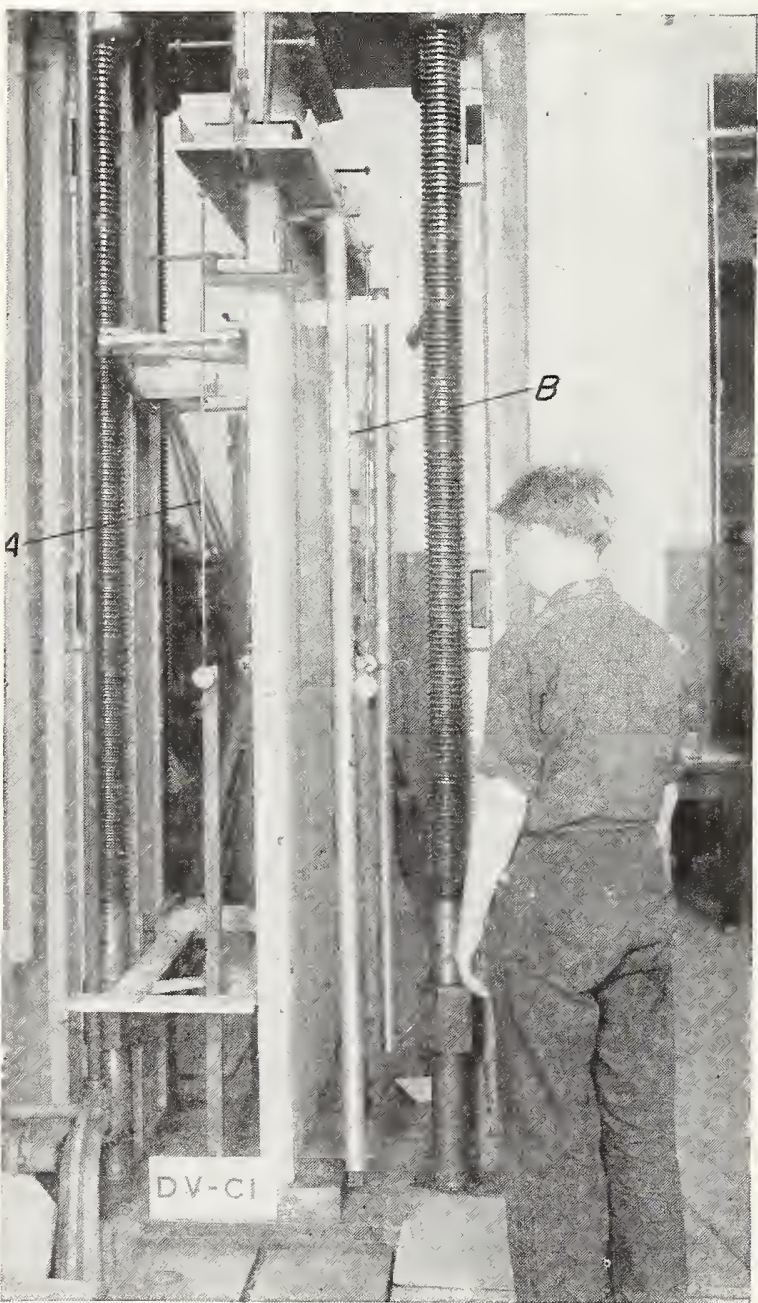

Figure 11. Wall specimen DT-C1 under compressive lould.

A, Compressometer; B. deflectometer.

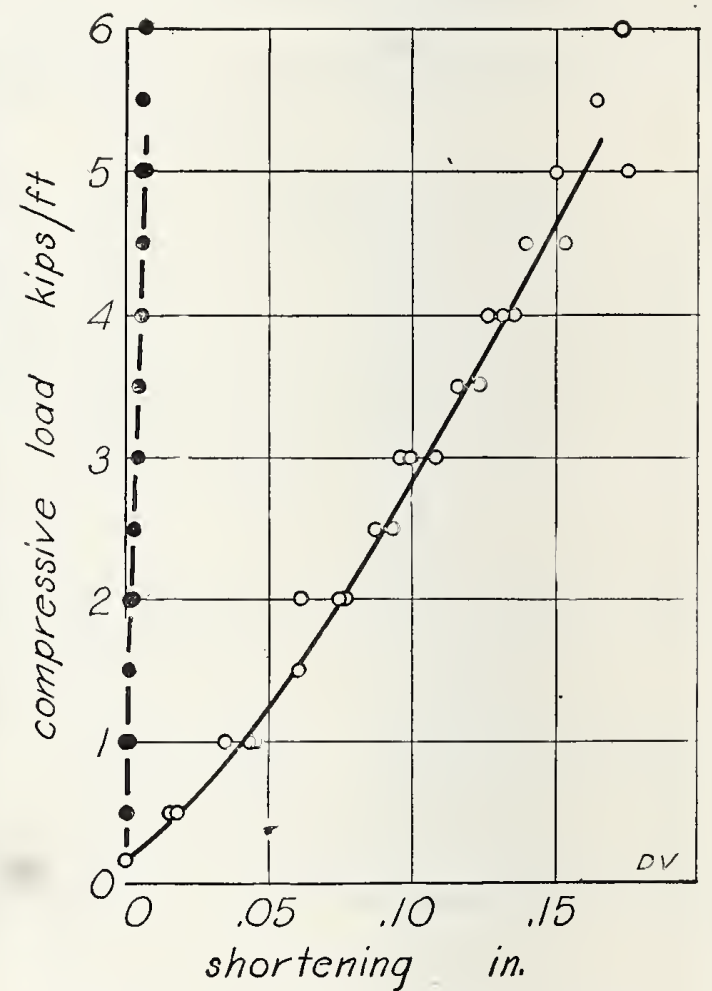

Figure 12.-Compressive load on wall $D \nabla$.

Load-shortening (open circles) and load-set (solid circles) resuits for specimens $D V-C 1, C 2, C 3$. The load was applied 102 in (one-third of the thickness of the panel) from the inside face. The loads are in kips per foot of actual width of specimen.

The shortenings and sets shown in figure 12 for a height of $8 \mathrm{ft}$ were obtained from the compressometer readings. The compressometers were attached to the plates through which 
the load was applied; the gage length was $8 \mathrm{ft}$. The lateral deflections plotted in figure 13 are deflections toward the outside face of the panels.

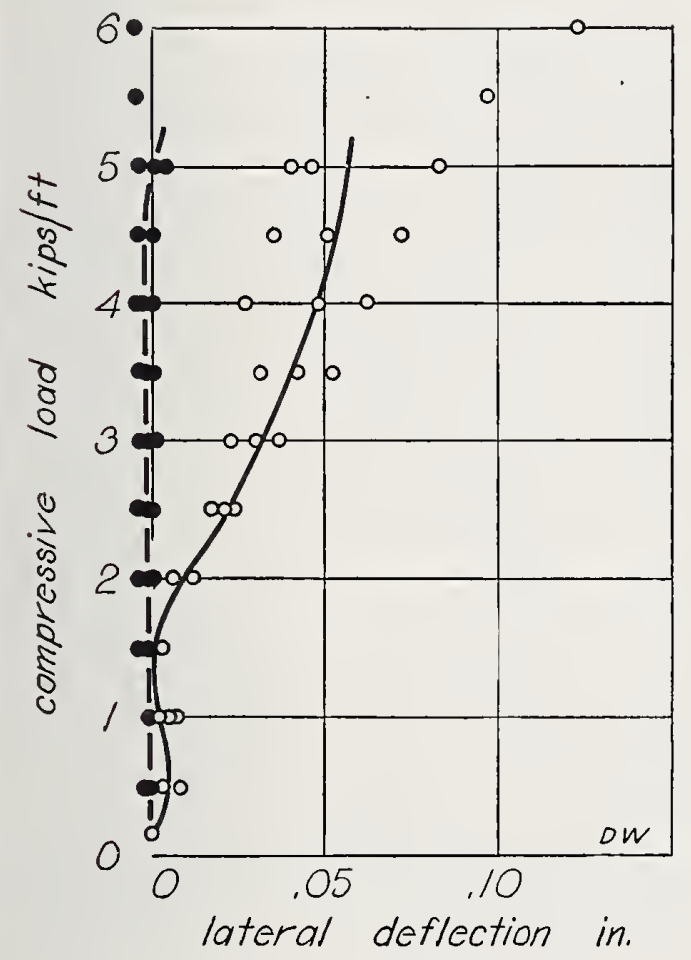

FIgURE 13.-Compressive load on wall $D V$.

Load-lateral deflection (open circles) and load-lateral set (solid circles) results for specimens $\mathrm{DV}-\mathrm{C1}, \mathrm{C2}, \mathrm{CB}$. The load was applied 1.02 in. (one-third of the thickness of the panel) from the inside face. The loads are in kips fer foot of actual width of specimen. The deflections and sets are for a gage length of $7 \mathrm{ft} 6 \mathrm{in}$, the gage length of the deflectometers.

The speed of the movable head of the testing machine was adjusted to $0.072 \mathrm{in.} / \mathrm{min}$.

Specimen $C \mathscr{Q}$ under a compressive load of 5.0 $\mathrm{kips} / \mathrm{ft}$ is shown in figure 14. The buckles between the studs are visible on the inside plywood face of the wall.

At a load of 4.25 and $6.48 \mathrm{kips} / \mathrm{ft}$ for specimens $C 1$ and $C 3$, respectively, loud noises were heard, probably caused by the failure of glue joints. At a load of $4.35,6.92$, and $6.48 \mathrm{kips} / \mathrm{ft}$ for specimens $C 1, C 2$, and $C 3$, respectively, crushing occurred under the top plate at the end of the studs. At a load of 5.53, 3.50 and $6.49 \mathrm{kips} / \mathrm{ft}$ for specimens $C 1, C 2$, and $C_{3}$, respectively, the inside face of the panel started to buckle. At a load of $7.92,10.87$, and 12.17 kips/ft for specimens $C 1, C 2$, and $C 3$, respec- tively, the insicle face separated from the spline. Under the maximum load, there was a compression failure of the inside face of specimen $C 2$ and splitting of the spline near the top of the panel of specimen $C 3$.

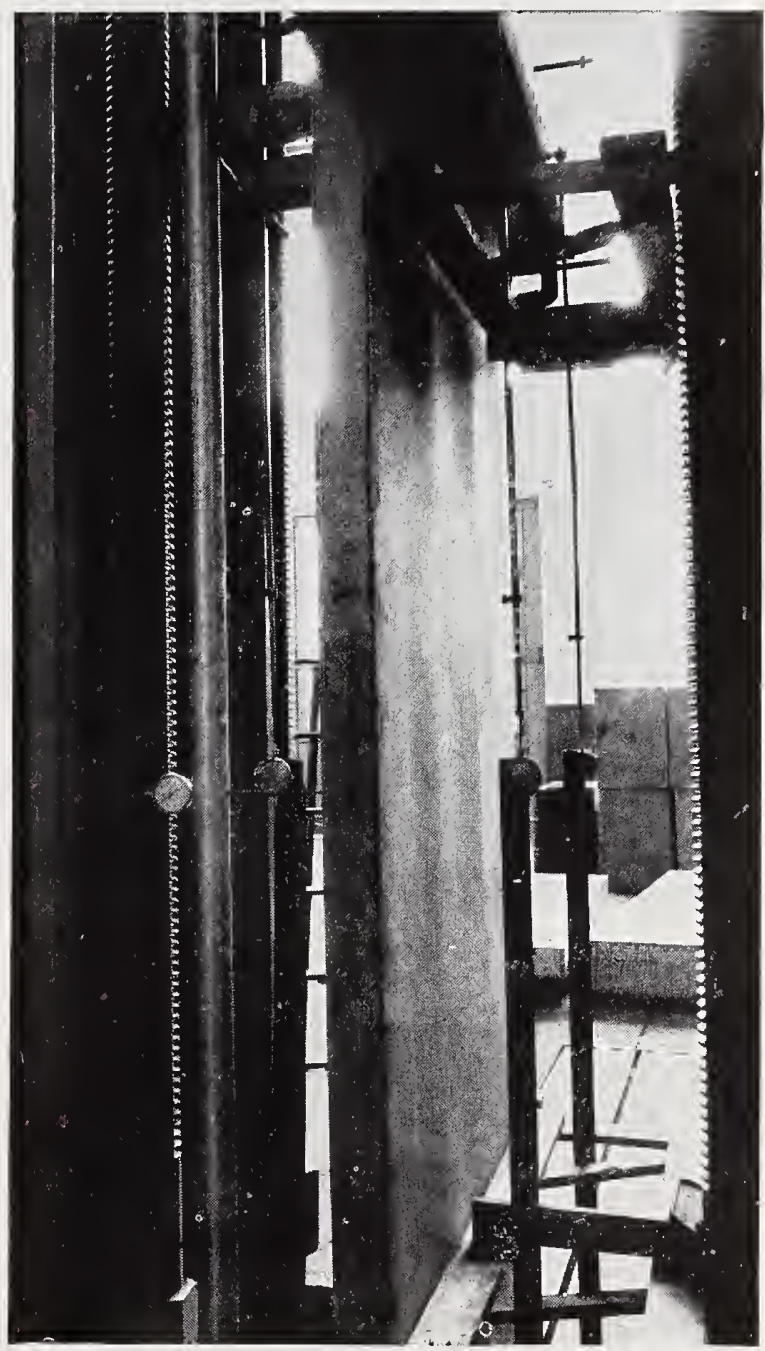

Figure 14.-Wall specimen DV-C2 under a compressive load of $5.0 \mathrm{kips} / \mathrm{ft}$.

Note the buckles in the inside plywood face of the wall.

Figure 15 shows the separation of the plywood inside face of specimen $C 1$ from the studs after the maximum load had been reached.

\section{Transverse Load}

The results of the transverse-load test are shown in table 4 and in figure 16 for wall specimens $D V-T 1, T 2$, and $T 3$, loaded on the inside face, and in figure 17 for specimens $D V-T 4, T 5$, and $T 6$, loaded on the outside face. 


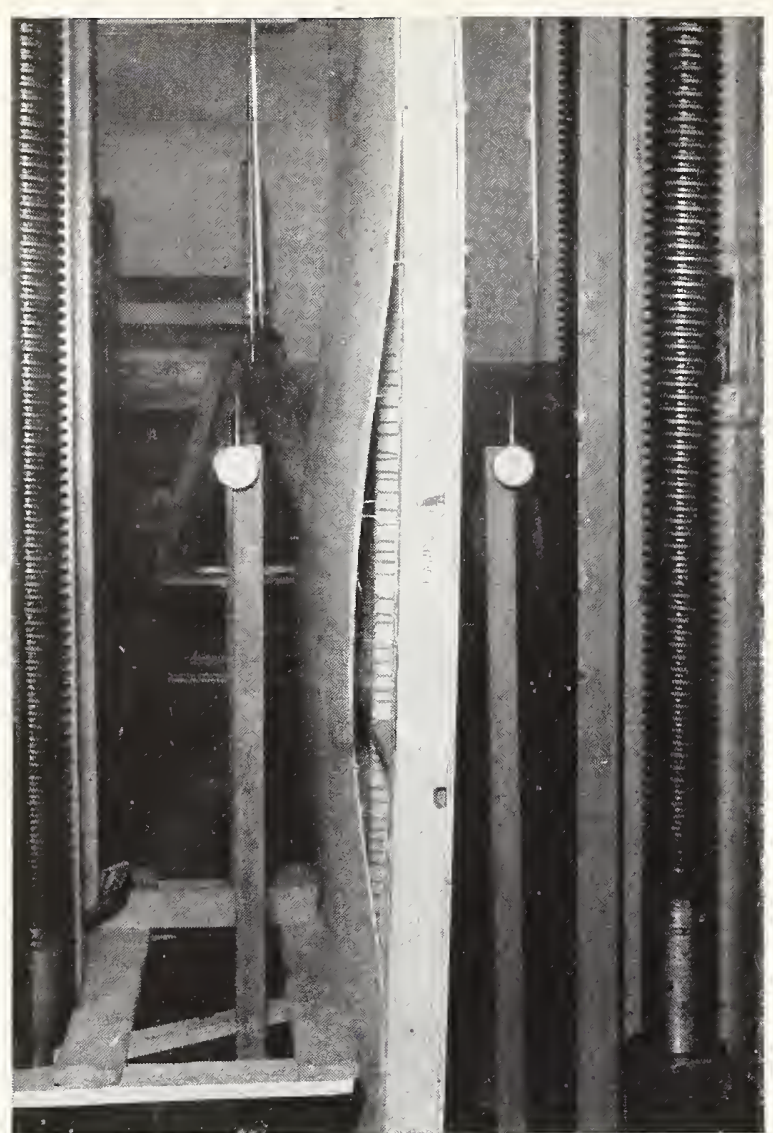

FuC IE 1.) - Hall specimen DV-C1 after the maximum compressive load had been reached.

The speed of the movable head of the testing machine was adjusted to $0.165 \mathrm{in} . / \mathrm{min}$.

The transverse loads were applied to the inside face of speeimens $D T-T 1, T 2$, and $T$. For specimens T1, T\%, and T.3, respectively, the inside face began to buckle between the loading rollers at a load of 140,100 . and $\left.1 i^{2}\right) \mathrm{lb} / \mathrm{ft}^{2}$; loud noises, probably caused by the failure of glue joints, were frist lieand at a load of $1+9$, 183 , and $2051 \mathrm{lb} / \mathrm{ft}^{2}$; and the inside face began to separate from the half splines at a load of 257,253 , and $308 \mathrm{lb} / \mathrm{ft}^{2}$. On specimen $7: 2$, the plywood on the inside face split near the half splines at a load of $262 \mathrm{lb} / \mathrm{ft}^{2}$ and one half spline broke in tension at a lnot at a load of $274 \mathrm{lb} / \mathrm{ft}^{2}$. Under the maximum load, a half spline in each specimen failed in tension. Examination of the specimens after test disclosed horizontal shear failures in an inner and an end stud of T1, compressive failures in two inner studs and one outer stud of $T \Omega$, and compressive failures in four studs of $T 3$.

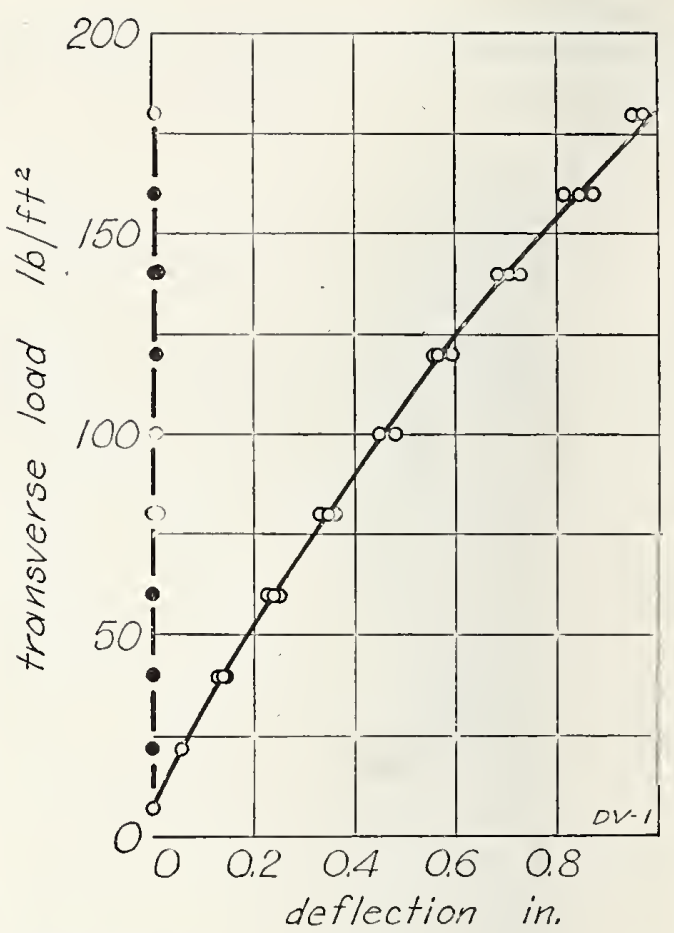

Figure 16.-Transverse load on uall DV, load applicd to inside fare.

Load-deflection (open circles) and load-set (solid circles) results for specimens $D T-T 1, T 2$, and $T 3$ on the span 7
ft 6 in. The loar (pounds per square foot) is the total ft 6 in. The loar (pounds per square foot) is the total of the specimen.

The transverse loads were applied to the outside face of specimens $D T^{-}-T / 4, T 5$, and $T 6$. For specimen $T$, loud noises were heard at a load of $135 \mathrm{lb} / \mathrm{ft}^{2}$, and continued to be heard until the test was discontinued, apparently indicating the failure of glue joints. At $15 \% \mathrm{lb} / \mathrm{ft}^{2}$ the outside face began to buckle between rollers. At $271 \mathrm{lb} / \mathrm{ft}^{2}$ the inside face failed in tension under one loading roller. The inside plywood buckled at $303 \mathrm{lb} / \mathrm{ft}^{2}$. One spline failed in tension at $306 \mathrm{lb} / \mathrm{ft}^{2}$. Examination after test showed that one inner stud had failed in compression. For specimen T5, the loud noises were first heard at a load of $157 \mathrm{lb} / \mathrm{ft}^{2}$. The outside plywood began to buckle at 180 $\mathrm{lb} / \mathrm{ft}^{2}$, and the inside plywood began to buckle at $219 \mathrm{lb} / \mathrm{ft}^{2}$. Tensile cracks appeared in the inside plywood at $246 \mathrm{lb} / \mathrm{ft}^{2}$ and $251 \mathrm{lb} / \mathrm{ft}^{2}$ near midspan. Examination after test disclosed a horizontal shear failure in one stud. On specimen $T 6$, the outside plywood began to buckle at $160 \mathrm{lb} / \mathrm{ft}^{2}$, and loud noises were first heard at $315 \mathrm{lb} / \mathrm{ft}^{2}$. Under the maximum load, one 
spline failed in horizontal shear and in tension. Examination after test disclosed compressive failures in three studs and horizontal shear failures in two studs.

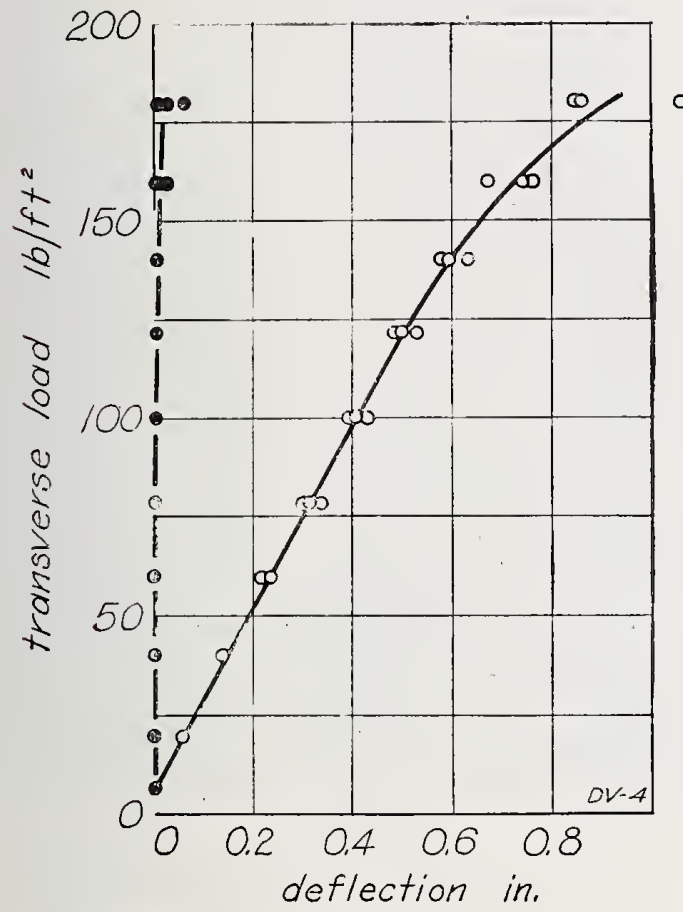

Figure 17.-Transverse load on wall $\mathrm{DV}$, load applicd to outsidc face.

Load-deflection (open circles) and load-set (solid circles) results for specimens $D T^{T}-T, T \delta$, and $T 6$ on the span 7 ft if in. The load (pounds per square foot) is the total loarl divided by the product of the span and the width of the spceinem.

\section{Concentrited Lond}

The results of the concentrated-load test are shown in table 4 and in figure 18 for wall specimens $D V-P 1, P 2$, and $P .3$, loaded on the inside face, and in figure 19 for wall specimens $D V-P / 4, P 5$, and $P C$, loaded on the outside face.

The concentrated load was applied to specimens $D T-P 1, P O$, and $P 3$ midway between two of the studs and $151 / 2$ in. from one end. Each of the specimens $D T^{2}-P 1, P Q$, and $P 3$ failed $\mathrm{b}_{J}$ the disk punching through the plywood.

The concentrated load was applied to specimen $D V-P / 4$ midway between two of the studs and $15 \frac{1}{2}$ in. from one end and to specimens $D V-P 5$ and $P G$ midway between two of the studs and $131 / 2$ in. from one end. The set, after a load of $1,000 \mathrm{lb}$ had been applied to $P / 4$, was 0.068 in. Specimens $P 5$ and $P 6$ failed by punching through the plywood at the maximum load.

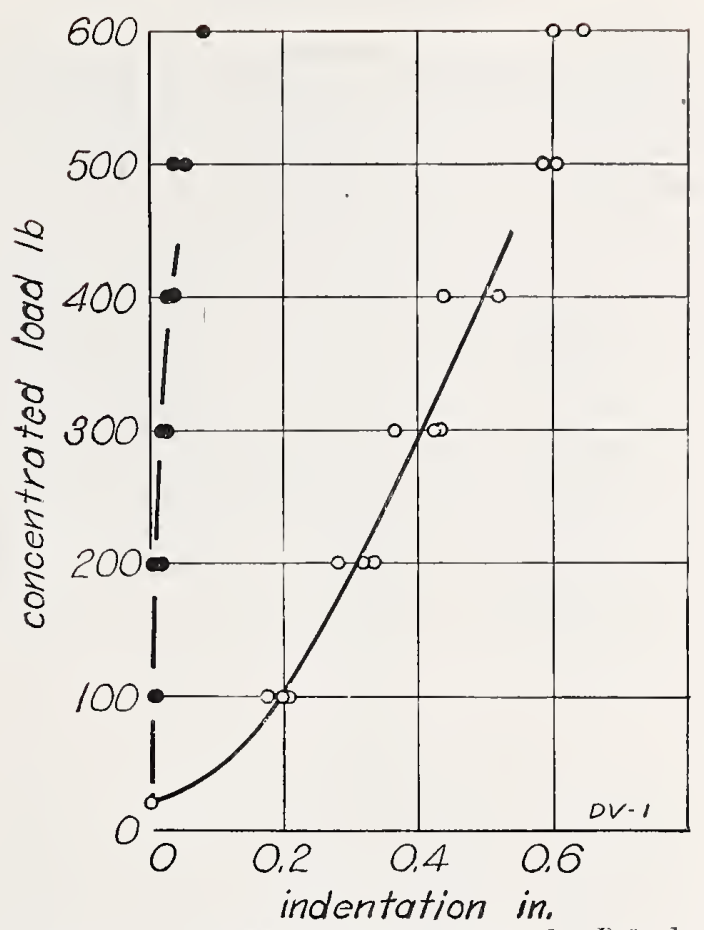

Figure 18.-Concentrated load on wall DV, load applied to inside face.

Load-indentation (open circles) and load-set (solid circles) results for specimens $D V \cdot P 1, P 2$, and $P 3$.

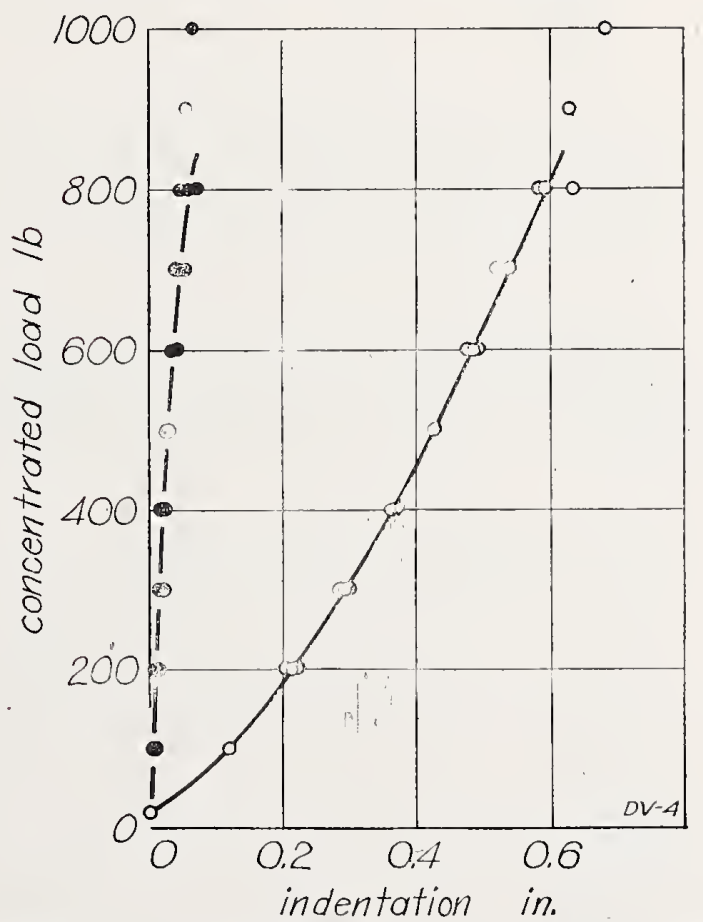

Figure 19.-Concentrated load on wall DV, load applied to outside face.

Load-indentation (open circles) and load-set (solid circles) results for specimens $D V_{-1} 4, P 5$, and $P 6$. 


\section{Impact Load}

The results of the impact-load test are given in table 4 and in figure 20 for specimens $D V-I 1, I 2$, and $I 3$ loaded on the inside face, and in figure 21 for specimens $D V-14,15$, and $I 6$, loaded on the outside face.

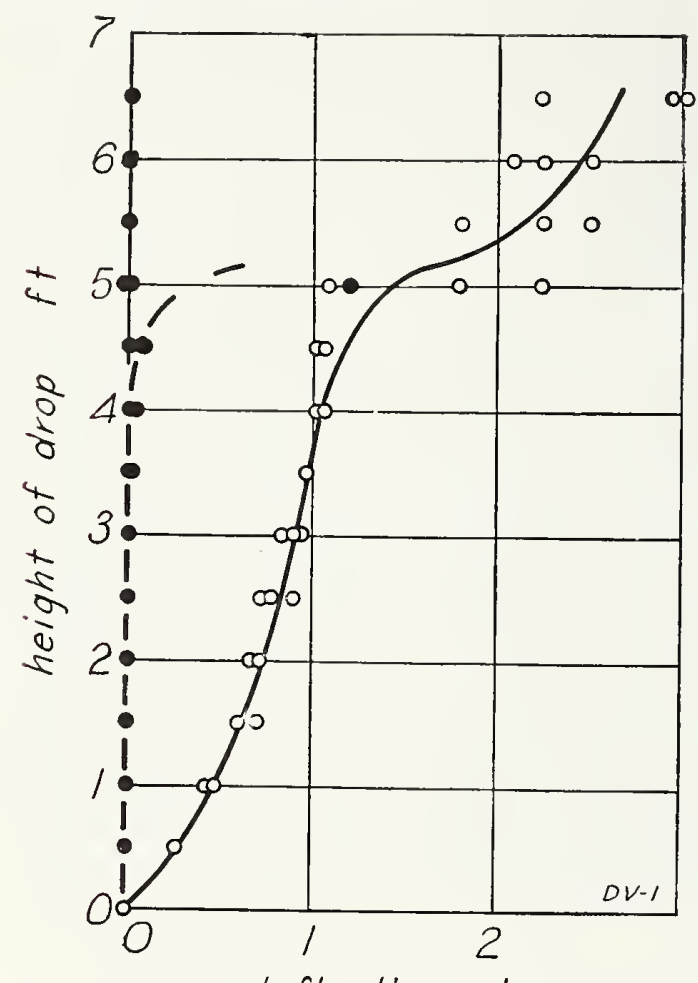

deflection in.

IGURe 20.- Impact load on wall DV, load applied to inside face.

Ifeight of drop-deflection (open circles) and height of dropset (solid circles) results for specimens $D V-I 1, I 2$, and 13 on the span 7 it 6 in.

The impact loads rere applied to the inside face of specimens $D V-I 1, I 2$, and $I 3$, the sanclbag striking the center of the specimen midway between two studs. The effects are given in table 5 .

TABLE 5.-Effects of impact load on wall specimens DV-I1, 12, and 13, loaded on inside face

\begin{tabular}{|c|c|c|c|c|c|c|}
\hline \multirow{2}{*}{ Description of effects } & \multicolumn{2}{|c|}{ Specimen $I 1$} & \multicolumn{2}{|c|}{ Specimen 12} & \multicolumn{2}{|c|}{ Specimen Is } \\
\hline & $\begin{array}{c}\text { Height } \\
\text { of } \\
\text { drop }\end{array}$ & $\underset{\text { flection }}{\mathrm{De}-}$ & $\begin{array}{c}\text { Height } \\
\text { of } \\
\text { drop }\end{array}$ & $\begin{array}{c}\text { De- } \\
\text { fiection }\end{array}$ & $\begin{array}{c}\text { Height } \\
\text { of } \\
\text { drop }\end{array}$ & $\begin{array}{c}\text { De- } \\
\text { flection }\end{array}$ \\
\hline & ft & in. & $f t$ & in. & $f t$ & in. \\
\hline $\begin{array}{l}\text { Face loaded: } \\
\text { Crack in plywood }\end{array}$ & & & 2.5 & 0.90 & 3.5 & 0.96 \\
\hline $\begin{array}{l}\text { Face broke where sand- } \\
\text { bag struck }\end{array}$ & 5.0 & 1. 08 & 4.5 & 1.07 & 4.5 & 1.02 \\
\hline $\begin{array}{l}\text { Face not loaded: } \\
\text { Crack in ply wood....- }\end{array}$ & & -..- & 6.0 & 2.25 & 6.0 & 2.08 \\
\hline $\begin{array}{l}\text { Separation of face from } \\
\text { studs }\end{array}$ & 6.0 & 2.50 & & & 6.5 & 2.23 \\
\hline
\end{tabular}

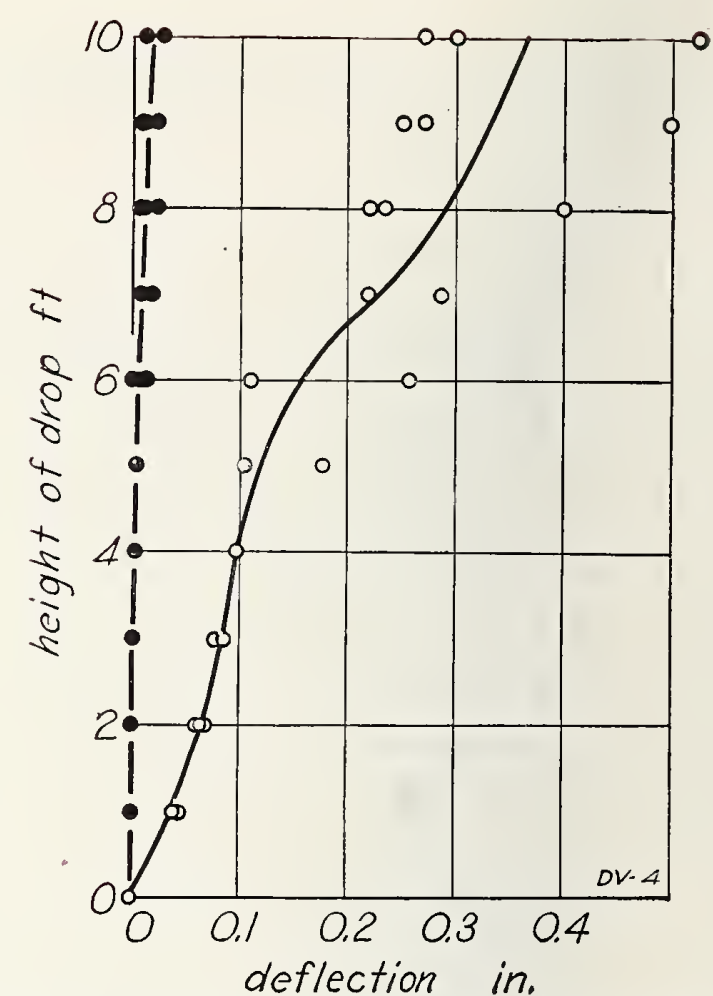

Figure 21.-Impact load on wall $D V$, load applied to outside face.

Height of drop-deflection (open circles) and height of dropset (solid circles) results for specimens $D V-14,15$, and 16 on the span $i$ ft 6 in.

The impact loads were applied to the outside of specimens $I V-I 4, I 5$, and $I 6$, the sandbag striking the center of the specimen midway between two studs. After a 4 -ft drop, I4 developed a long crack in the outside (loaded) face under the bag.

The deflection was $0.93 \mathrm{in}$. The inside face separated from the spline and stud on one side after a 7 -ft drop. The deflection was $2.86 \mathrm{in}$. In 15 , the $51 / 2$-ft drop produced a noise that apparently indicated a glue failure; the deflection was $1.01 \mathrm{in}$. In $l G$, the $61 / 2-\mathrm{ft}$ drop produced a noise that apparently indicated a glue failure. The deflection was $1.57 \mathrm{in}$.

After the 10-ft drop, the set in specimen $I / 4$ was $0.282 \mathrm{in.}$; in $\mathrm{I5}, 0.122 \mathrm{in.}$; and in $\mathrm{I} 6$, $0.121 \mathrm{in}$.

\section{Raching Load}

Wall specimen $D T-R 1$ under racking load is shown in figure 22 . The results of the rackingload test for specimen $D V-R 1, R 2$, and $R 3$ are given in table 4 and figure 23. 


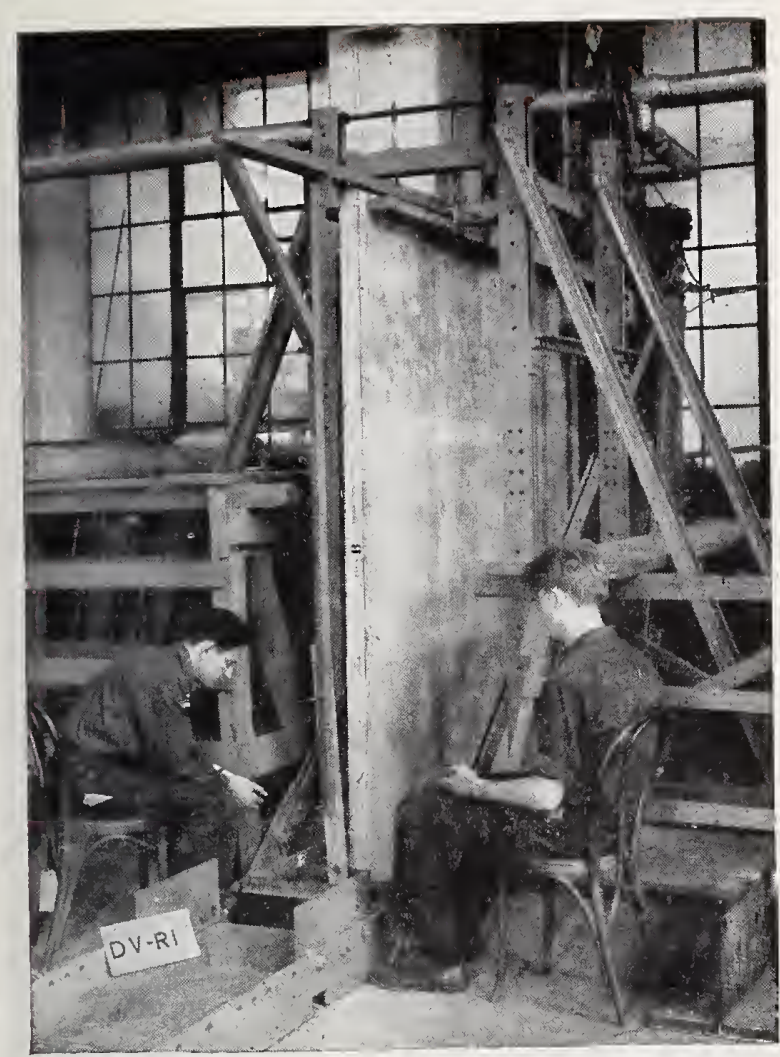

FIgUre 22.-Wall specimen II-R1 under racking load.

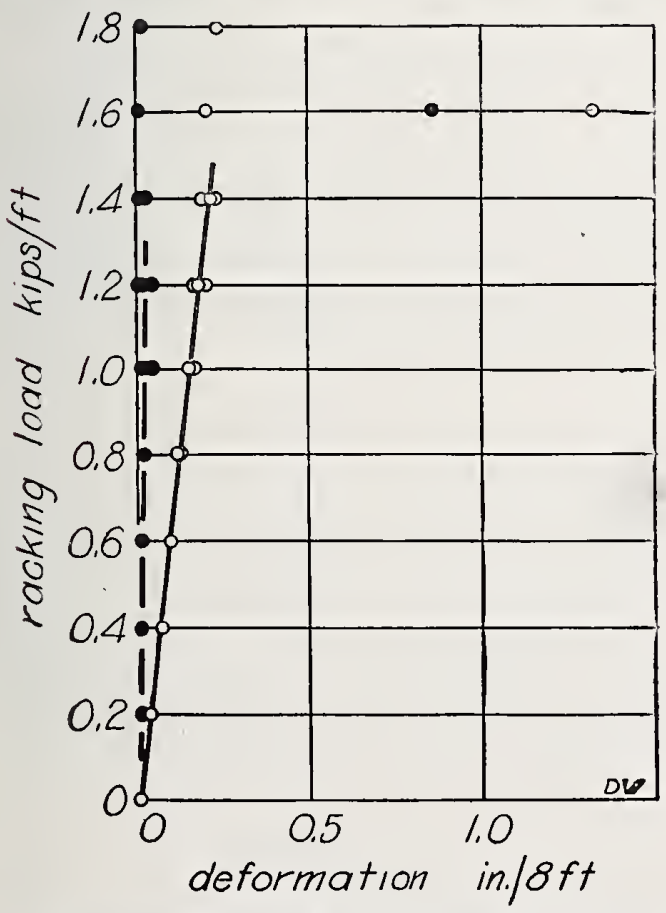

Frgure 23.-Racking load on wall $D V$.

Load-deformation (open circles) and load-set (solid circles) results for specimens $D V-R 1, R 2$, and $R 3$. The loads are in kips per toot of actual width of specimen.
The racking loads were apphed to the top plate, and the stop was in contact with the bottom plate at the diagonally opposite corner of the specimen. Under a load of $1.50 \mathrm{kips} / \mathrm{ft}$, the two 4 - by 8-ft plywoorl sheets on each side of the specimen $R 1$ exhibited relative vertical displacement. Crushing occurred at the front lower plate, and the top plate failed in compression under the maxinum load. A noise, apparently glue failure, was heard at $0.8 \mathrm{kip} / \mathrm{ft}$ in specimen $R \Omega$. At $2.2 \mathrm{kips} / \mathrm{ft}$ crushing occurred at the bottom plate and at $2.3 \mathrm{kips} / \mathrm{ft}$ the top plate sheared from the plywood.

Under maximum load, the top plate crushed. A loud noise, apparently glue failure, and crushing of the top plate occurred at 0.97 $\mathrm{kip} / \mathrm{ft}$ in P.3. The bottom plate at the stop began to fail in crushing at $1.27 \mathrm{kips} / \mathrm{ft}$.

\section{PARTITION $D W$ \\ 1. Sponsol's St.tenent}

Partition $D W$ was like wall $D V$, except that both faces were like the inside face of the wall specimens. The partition specimens were assembled and fastened together in the same manner as the wall specimens.

The price of this construction in Washington, D. C., as of July 1937 was $\$ 0.24 / \mathrm{ft}^{2}$.

\section{(a) Four-Foot Partition Specimens}

The 4-ft partition specimens shown in figure 21 were $8 \mathrm{ft} 0 \mathrm{in}$. high, $3 \mathrm{ft} \mathrm{113/4}$ in. wide, and 3 in. thick. Each was a wood frame to which the faces were fastened. The frame consisted of four studs, $A$, fastened to transverse members, $B$, at top and bottom. There were two lines of blocks, $C$, extending between the studs. Faces, $D$, each consisted of one piece of plywood. Plates, $E$, extended across the top and bottom ends of the specimens, and half splines, $F$, were inserted between the faces at the sides.

Studs.-The studs, A, were Douglas fir, $25 / 32$ by $21 / 2$ in. (nominal 1 by 3 in.) $7 \mathrm{ft} 71 / 2$ in. long, spaced $1 \mathrm{ft} 3 \mathrm{in}$. on centers.

Transverse members.-The transverse members, $B$, were Douglas fir, $25 / 32$ by $21 / 2 \mathrm{in}$. (nominal 1 by $3 \mathrm{in.)} 3 \mathrm{ft}$ 101/4 in. long, extending across the ends of the studs. The transverse members were fastened to the studs by $6 \mathrm{~d}$ box nails driven through the transverse members into the ends of the studs, two nails to each stud end.

Blocks.-Blocks, $C$, were Douglas fir. $25 / 32$ by $2 \frac{1}{2}$ in. (nominal 1 by 3 in.) $1 \mathrm{ft} 2 \frac{1}{4}$ in. 


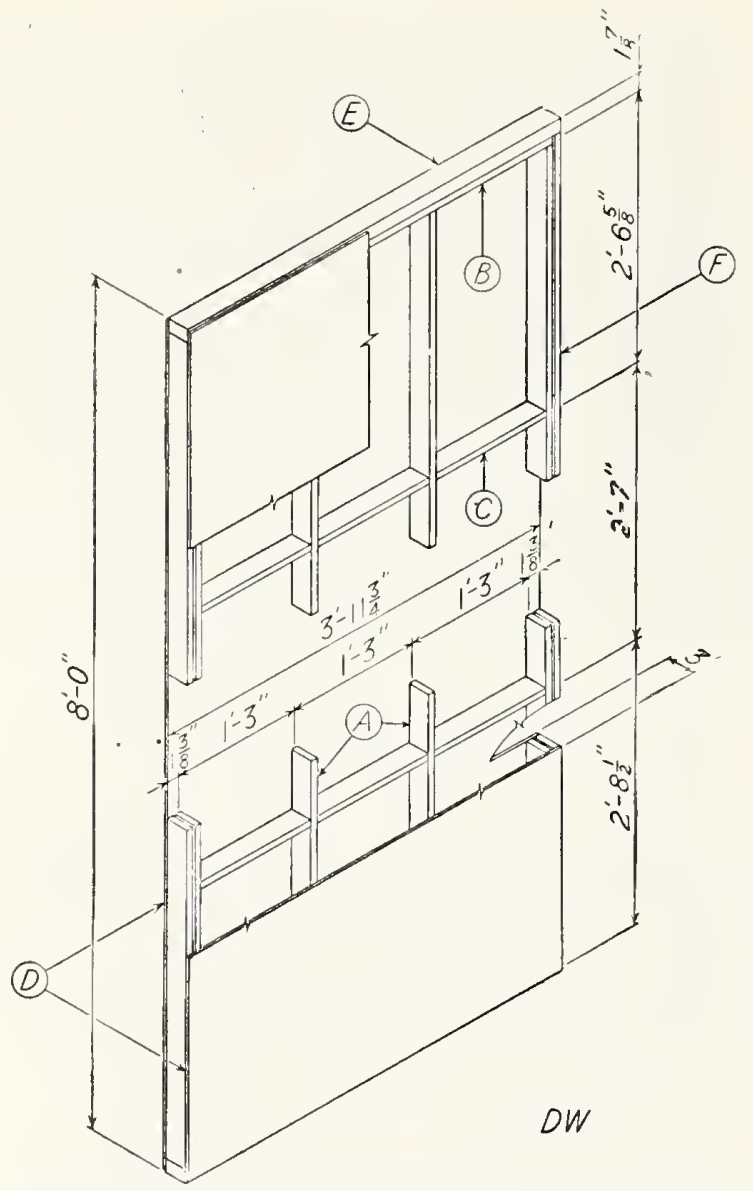

FIGURE 24.-Four-foot partition specimen $D \mathrm{~W}$. $A$, Stud; $B$, transverse member; $C$, block; $D$, face; $E$, plate; $F$, half spline.

long, inserted between the studs in two lines about equidistant from the transverse members and each other. The blocks were fastened to the studs by $6 \mathrm{~d}$ box nails. Two nails were driven through the outer studs into the ends of the outer blocks and one nail through each stud.

Faces.-Faces, $D$, were each one piece of Douglas fir plywood, moisture-resistant type, $1 / 4$ in. thick, $8 \mathrm{ft} 0 \mathrm{in}$. long, and $3 \mathrm{ft} \mathrm{113/4} \mathrm{in}$. wide. Each face was fastened by glue to all the frame members, which had been coated with the glue mixture.

Plates.-Both floor and top plates, $E$, were Douglas fir, $11 / 2$ by $21 \%$ in. (nominal 2 by 3 in.) $3 \mathrm{ft} 113 / 4$ in. long. The plates were inserted between the faces of the specimens after the faces had been attached to the frames, and were fastened in place by $6 \mathrm{~d}$ box nails driven through the faces and spaced approximately 6 in. apart. There were also three $8 d$ common nails driven through each plate into the transverse member, spaced about halfway between the studs. In some specimens, glue had been partially applied to the sides of the plates, but in other cases this was omitted.

Half splines.-IIalf splines, $F$, were Douglas fir, $25 / 32$ by $21 / 2 \mathrm{in}$. (nominal 1 by $3 \mathrm{in}$.) $7 \mathrm{ft}$ $9 \mathrm{in}$. long. The half splines were inserted between the faces of the specimens after the faces had been attached to the frames, and were fastened in place by $6 \mathrm{~d}$ box nails driven through the faces and spaced approximately 6 in. apart. In some specimens, glue had been partially applied to the sides of the half splines, but in other cases, this was omitted.

\section{(b) Eight-Foot Partition Specimens}

The 8-ft partition specimens, shown in figure 25 , were $8 \mathrm{ft} 0 \mathrm{in}$. high, $7 \mathrm{ft} 111 / 2 \mathrm{in}$. wide, and 3 in. thick. The specimens consisted of two 4-ft panels like the 4 -ft specimens, joined together and held in place by continuous plates, $E$, at top and bottom; and full size spline, $G$, between the specimens.

Plates.-Plates, $E$, were similar to those for the 1 - $\mathrm{ft}$ specimens, and were fastened in the . Same way but were $7 \mathrm{ft} 11 \frac{1}{2} \mathrm{in}$. long.

Spline.-Spline, $G$, was Douglas fir, $11 / 2$ by $2 \frac{1}{2}$ in. (nominal 2 by 3 in.) $7 \mathrm{ft} 9$ in. long. The spline was inserted between the faces of the adjoining panels, and the panels were fastened by $6 \mathrm{~d}$ box nails driven through the faces into the spline along the adjacent edges. The spacing was about 6 in.

\section{(c) Comments}

The partitions of a house consist of panels similar to the 4-ft specimens, joined together and held in place by continuous plates at top and bottom, and wood splines as represented by the construction of the 8 - $\mathrm{ft}$ specimens. Openings for doors are provided by specially constructed panels. The surfaces of this construction are usually finished with paint.

\section{Compressive Load}

The results of the compressive-load test for partition specimens $D \mathrm{~W}-\mathrm{Cl}, \mathrm{C} \Omega$, and $C 3$ are given in table 6 and in figures 26 and 27. 


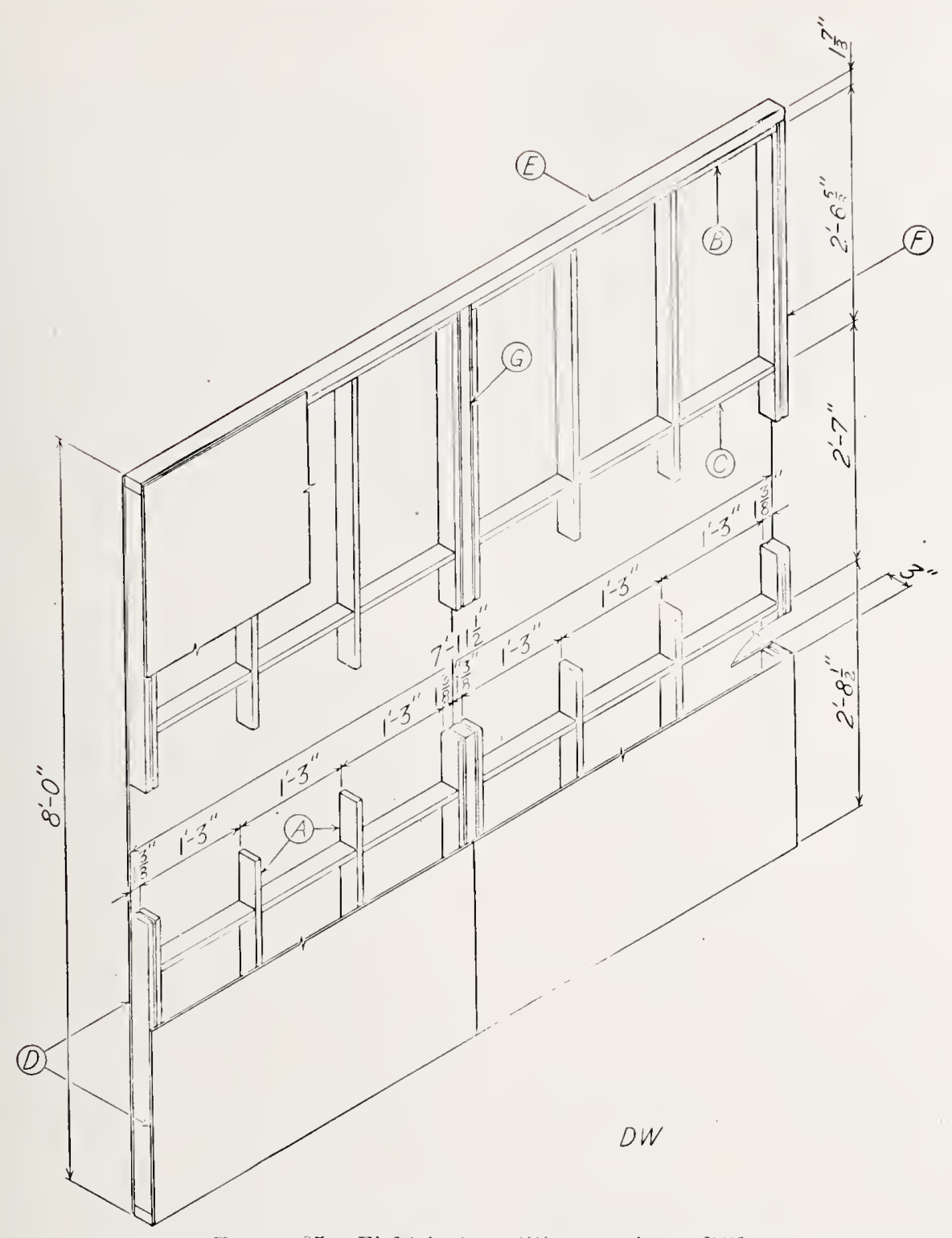

FIGURE 25-Eight-foot partition specimen 1 W.

$A$, Stud ; $I$, transrerse member; $C$, block; $D$, face ; $E$, plate; $F$, half spline ; $G$, spline.

TABLE 6.-Structural propertics of partition DW' [Weight, based on face area: $2.61 \mathrm{lb} / \mathrm{ft}^{2}$ ]

\begin{tabular}{|c|c|c|c|c|c|c|c|c|c|}
\hline \multicolumn{2}{|c|}{ Compressive loada } & \multicolumn{2}{|c|}{$\begin{array}{c}\text { Transwerse load; span, } \\
7 \text { ft } 6 \mathrm{in} \text {. }\end{array}$} & \multicolumn{2}{|c|}{$\begin{array}{l}\text { Conecntrated load; disk, } \\
\text { diam } 1 \text { in. }\end{array}$} & \multicolumn{2}{|c|}{$\begin{array}{l}\text { Impact load; span, } \\
7 \mathrm{ft} 6 \text { in.; sandbag, } 60 \mathrm{lb}\end{array}$} & \multicolumn{2}{|c|}{ Racking load } \\
\hline Speeimen & $\underset{\text { load }}{\text { Maximun }}$ & Specimen & $\begin{array}{c}\text { Maximum } \\
\text { load }\end{array}$ & Specimen & 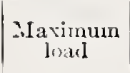 & Specimen & $\underset{\text { load }}{\text { Maximum }}$ & Specimen & $\underset{\text { load }}{\text { Maximum }}$ \\
\hline$\cdots$ & $\begin{array}{r}\text { Kips } / f t \mathrm{~b} \\
8.55 \\
8.71 \\
9.47\end{array}$ & $\begin{array}{l}\text { T1 } \\
\text { T2 } \\
T 33_{3}\end{array}$ & $\begin{array}{r}b b / f t^{2} \\
233 \\
278 \\
296 \\
296 \\
\end{array}$ & $\begin{array}{l}P 1 \\
P 2 \\
P B\end{array}$ & $\begin{array}{r}521 \\
700 \\
500 \\
\end{array}$ & $\begin{array}{l}I 1-\ldots- \\
I 2-\ldots \\
I 3-\ldots\end{array}$ & $\begin{array}{r}f t \\
6.0 \\
8.0 \\
7.0\end{array}$ & $\begin{array}{l}R 1 \\
R P_{2} \\
R S_{-}\end{array}$ & $\begin{array}{r}\text { Kips/ftb } \\
1.80 \\
1.91 \\
1.79\end{array}$ \\
\hline Average & 8.91 & Average & 269 & Average & 574 & Average & 7.0 & Average -- & 1.83 \\
\hline
\end{tabular}

a Load applied 0.98 in. (1/3 thickuess of the panel) from 1 fuce. b A kip is $1,000 \mathrm{lb}$. 
The shortenings and sets were obtained from the compressometer readings for a height of $8 \mathrm{ft}$. The compressometers were attached to the plates through which the load was applied; the gage length was $8 \mathrm{ft}$. The lateral deflections plotted in figure 27 were deflections toward the outside face of the panel. The speed of the movable head of the testing machine was adjusted to $0.072 \mathrm{in} . / \mathrm{min}$.

For specimens $C 1, C$, and $C 3$, respectively, the compressive face buckled at a load of 3.00 , 4.00, and $3.50 \mathrm{kips} / \mathrm{ft}$. Loud noises indicating glue failure were heard at a load of $4.00,6.00$, and $4.50 \mathrm{kips} / \mathrm{ft}$.

The studs began to crush into the top plate at $4.67,5.50$, and $5.00 \mathrm{kips} / \mathrm{ft}$. The plywood on the inside face started separating from the panel at $7.16,4.45$, and $6.67 \mathrm{kips} / \mathrm{ft}$. The outside face of $C 3$ began separating and buckled at $6.67 \mathrm{kips} / \mathrm{ft}$.

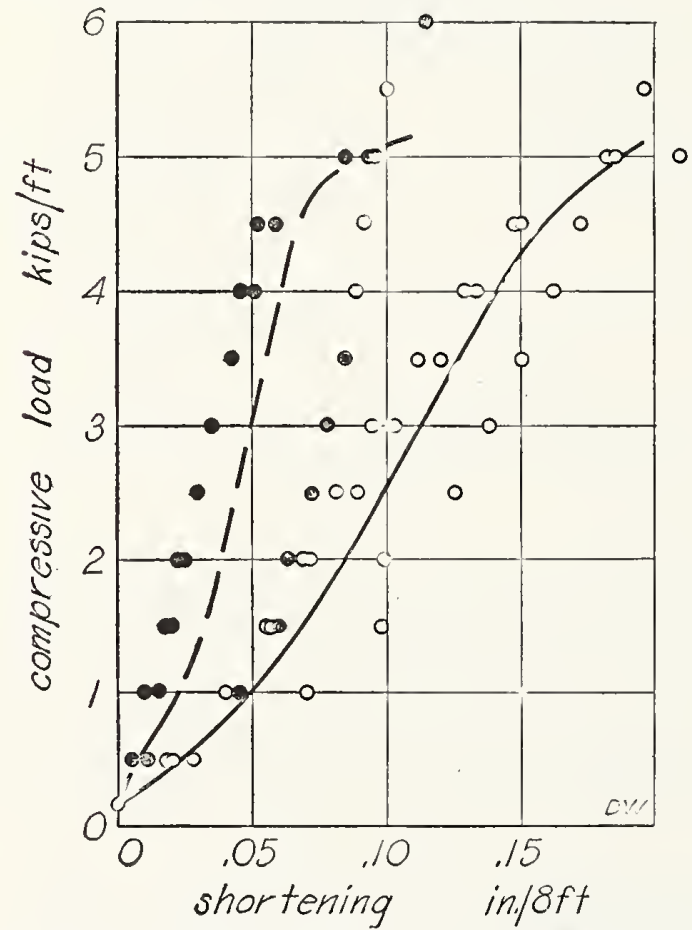

FIGURE 26.-Compressive load on partition $D W$.

Load-shortening (open circles) and load-set (solid circles) results for specimens $D W-C 1, C 2$, and $C 3$. The load was applied 0.98 in. (one-third the thickness of the panel) from one face of the panel. The loads are in kips per foot of actual width of specimen.

\section{Transverse Load}

The results under transverse load are given in table 6 and in figure 28 for specimens $D W-$ T1, T2, and T3. The speed of the movable head

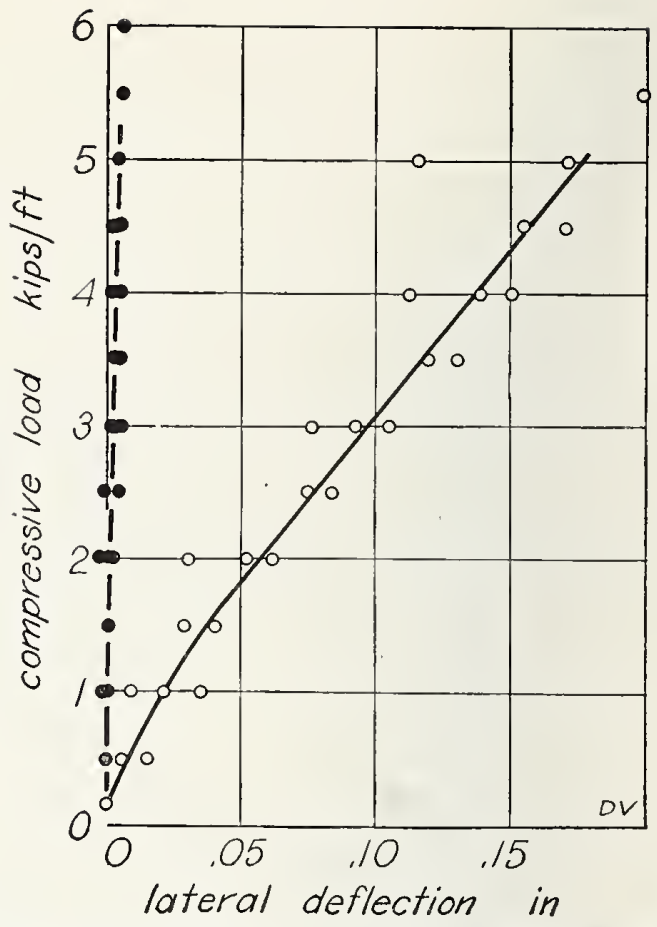

0

FIGURE 27.-Compressive load on partition $D W$. Load-lateral deflection (open circles) and load-lateral set (solid circles) results for specimens $D W-C 1, C 2$ and $C 3$. The load was applied 0.98 in. (one-third the thickness of the panel) from one face of the panel. The loads are in kips per foot of actual width of specimen.

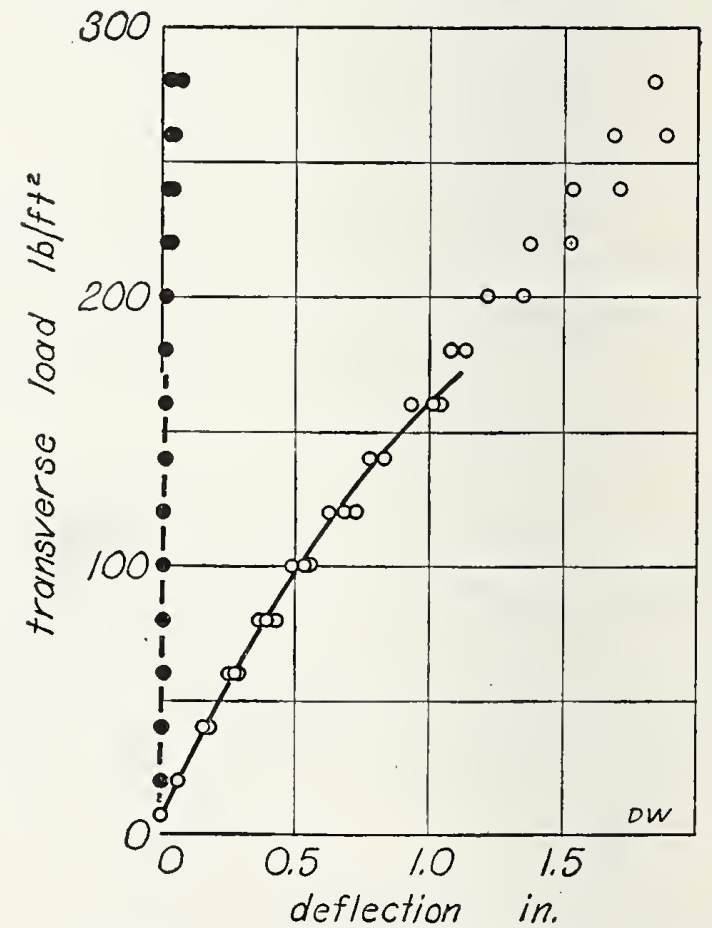

Figure 28.-Transverse load on partition $D W$. Load-deflection (open circles) and load-set (solid circles) results for specimens $D W-T 1, T 2$ and $T 3$, on the span 7 results for specimens $D W-T 1, T 2$ and $T 3$, on the span 7 by the product of the span and the width of the specimen. 
of the testing machine was adjusted to 0.172 in./min.

For specimens $T 1, T 2$, and $T 3$, respectively, the top plywood started to buckle at a load of 100,120 , and $160 \mathrm{lb} / \mathrm{ft}^{2}$. Noises were heard, apparently due to glue failure, at 182,239 , and $259 \mathrm{lb} / \mathrm{ft}^{2}$. At $140 \mathrm{lb} / \mathrm{ft}^{2}$ the upper plywood of $T 1$ separated from the splines. At 219 $\mathrm{lb} / \mathrm{ft}^{2}$ one spline broke, and at $228 \mathrm{lb} / \mathrm{ft}^{2}$ the other spline of $T 1$ failed in tension. The upper plywood of $T 2$ separated from the half splines at $262 \mathrm{lb} / \mathrm{ft}^{2}$. Under maximum load the lower plywood of $T 1$ failed in tension. Examination after test disclosed that in $T 1$ three inner studs failed in compression and two outer studs failed in tension; in TQ three studs failed in compression; and in $T 3$ two studs failed in compression.

\section{Concentrated Lond}

The results of the concentrated-load tests are given in table 6 and in figure 29 for specimens $D W-P 1, P 2$, and $P$.

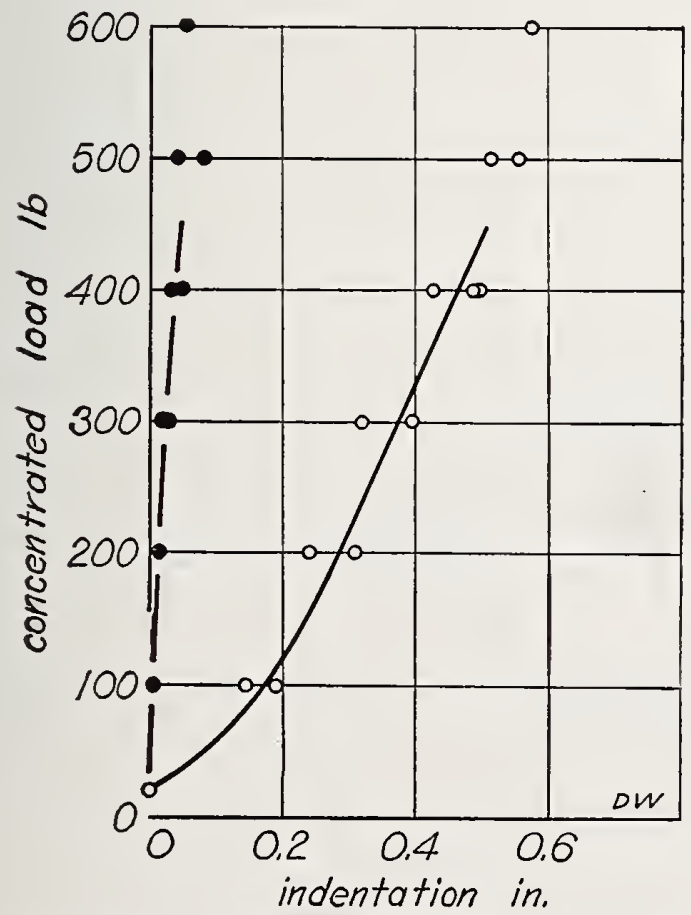

FIGLRE 29.-Concentrated load on partition $D W$.

Load-indention (open circles) and load-set (solid circles) results for specimens $D W \cdot P 1, P 2$, and $P 3$.
The concentrated load was applied to the face of specimens $D I V-P 1, P 2$, and $P 3$, midway between two studs and $151 / 2$ in. from one end. Under this maximum load on each specimen the disk punched through the plywood.

\section{Impact Load}

The results of the impact-load tests are given in table 6 and in figure 30 for specimens $D W$ -

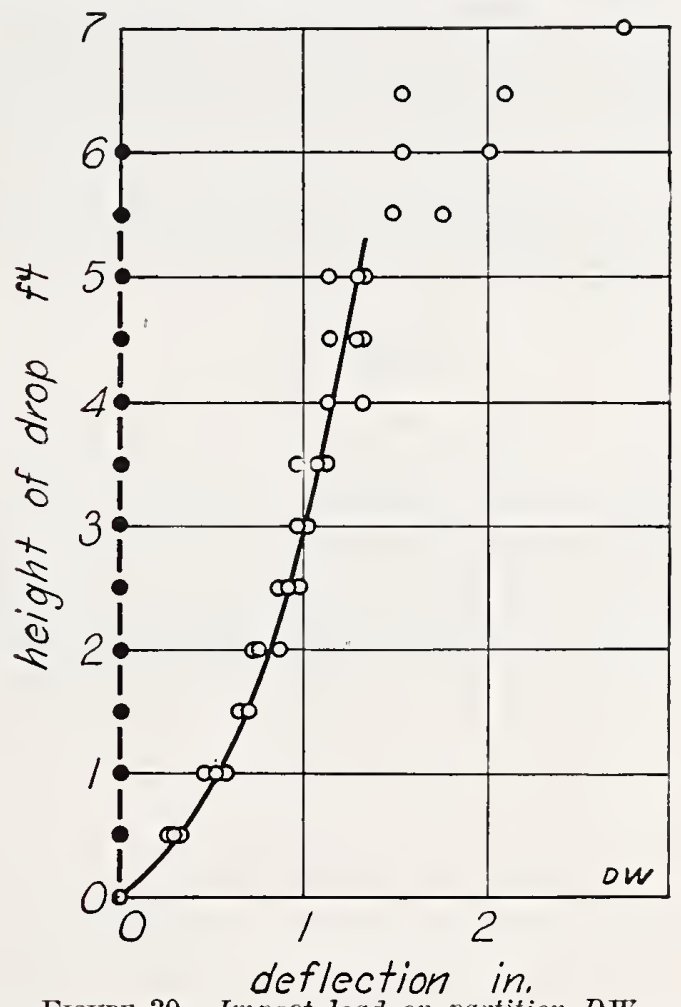

Figure 30.-Impact load on partition $D \mathrm{~W}$.

Height of drop-deflection (open circles) and height of dropset (solid circles) results for specimens $D W-I 1, I 2$, and $I S$ on the span 7 ft 6 in.

I1. I2, and 13 . The sandbag struck the center of the face, midway between two studs. The effects are given in table 7 .

TABLE 7.-Effects of impact load on partition specimens $D H-I 1, I 2$, and $I 3$

\begin{tabular}{|c|c|c|c|c|c|c|}
\hline \multirow{2}{*}{ Description of effects } & \multicolumn{2}{|c|}{ Specimen $I 1$} & \multicolumn{2}{|c|}{ Specimen 12} & \multicolumn{2}{|c|}{ Specimen $I S$} \\
\hline & $\begin{array}{c}\text { Height } \\
\text { of } \\
\text { drop }\end{array}$ & $\begin{array}{c}\text { De- } \\
\text { flection }\end{array}$ & $\begin{array}{c}\text { Height } \\
\text { of } \\
\text { drop }\end{array}$ & $\begin{array}{c}\text { De- } \\
\text { flection }\end{array}$ & $\begin{array}{c}\text { Height } \\
\text { of } \\
\text { drop }\end{array}$ & $\begin{array}{l}\text { De- } \\
\text { flection }\end{array}$ \\
\hline & $f t$ & in. & $f t$ & in. & $f t$ & in. \\
\hline $\begin{array}{l}\text { Face loaded: } \\
\text { Crack in plywood }\end{array}$ & $-\ldots$ & & 4.5 & 1. 14 & & \\
\hline $\begin{array}{l}\text { Face broke where sand- } \\
\text { bag struck }\end{array}$ & 4.5 & 1.33 & 5.0 & 1.14 & 6.0 & 1.53 \\
\hline $\begin{array}{l}\text { Face not loaded: } \\
\text { Crack in plywood }\end{array}$ & & & 7.0 & 2.75 & & \\
\hline $\begin{array}{l}\text { Face broke where sand- } \\
\text { bag struck }\end{array}$ & 5.5 & & 7.5 & & & \\
\hline
\end{tabular}




\section{Racking Loid}

The results under racking load for specimens $D W-R I, R 2$, and $R 3$ are shown in table 6 and figure 31.

The racking loads were applied to the top plate, and the stop was in contact with the bottom plate at the diagonally opposite corner of the specimen. Noises, apparently glue failure, were heard from specimens $R 1$ and $R ?$, respectively, and at a load of 0.90 and 1.12 kips/ft. The top plate started crushing in specimens $R 1, R$, and $R 3$ at a load of 1.78 , 1.56 , and $1.20 \mathrm{kips} / \mathrm{ft}$, respectively. The bottom plate started crushing at a load of $1.78,1.75$, and $1.60 \mathrm{lips} / \mathrm{ft}$. Under maximum load, the top plate of each specimen failed completely.

\section{FLOOR D.Y}

\section{Sponsor's Statement}

Floor D.Y was designed as a short-span floor panel and consisted of lightweight wood joists and solid bridging with plywood as both faces, the faces being fastened by ghe. The faces were subjected to a pressure of $86 \mathrm{lb} / \mathrm{in} .^{2}$ on the joist, header, and bridging surfaces for a period of 35 minutes while the glue hardened.

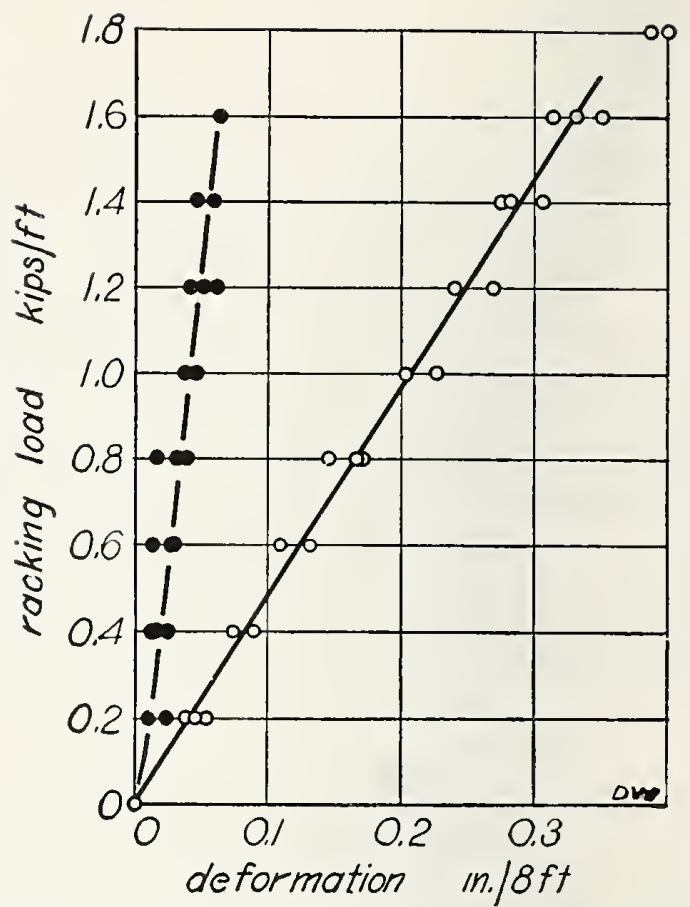

FIgure 31.-Racking load on partition $D W$.

Load-deformation (open circles) and load-set (solfd circles) results for specimens $D W-R 1, R 2, R 3$. The loads are in kips per foot of actual width of specimen.

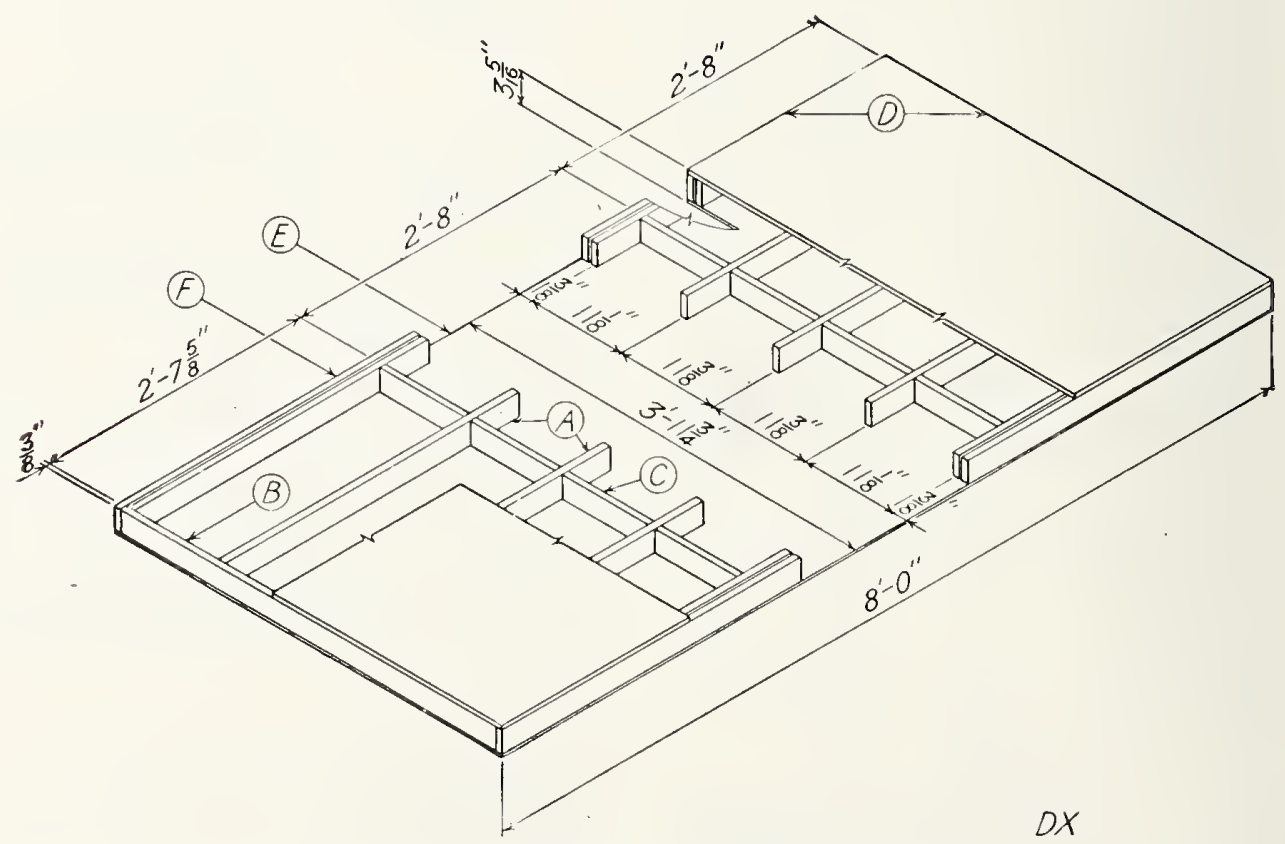

Figure 32-Floor $D X$.

$A$, jolst ; $B$, header ; $C$, bridging; $D$, flooring ; $E$, ceiling; $F$, half splines. 
To hasten the time of set, the temperature of air surrounding work in the presses was raised to $141^{\circ} \mathrm{F}$ by panels of infrared light. The specimens were not painted.

The price of this construction in Washington, D. C. as of July 1937 was $\$ 0.38 / \mathrm{ft}^{2}$.

\section{(a) Description of Specimens}

The floor specimens $D I$, shown in figure 32 , were $8 \mathrm{ft} 0 \mathrm{in}$. long, $3 \mathrm{ft} \mathrm{113/4}$ in. widle, and $35 / 16$ in. deep. Each specimen had five joists, $A$, fastened to headers, $B$. There were two lines of solid bridging, $C$, extending between the joists. Flooring, $D$, and ceiling, $E$, each consisted of one piece of plywood. IIalf splines, $F$, were inserted between the faces at the sides.

Joists.-The joists, A, were Douglas fir, $25 / 32$ by $21 / 2$ in. (nominal 1 by 3 in.) 7 ft. $10 \frac{1}{2}$ in. long, spaced $111 / 8$ in. and $113 / 8$ in. apart, as shown in figure 32.

IIeaders.-Headers, $B$, were Douglas fir, $25 / 32$ by $2 \frac{1}{2}$ in. (nominal 1 by 3 in.) 3 ft. $101 / 4$ in. long, extending across the ends of the joists. The headers were fastened to the joists by $6 \mathrm{~d}$ box nails driven through the headers into the ends of the joists, two nails into each joist end.

Bridging.-The solid bridging, $C$, was Douglas fir, $25 / 32$ by $21 / 2$ in. (nominal 1 by 3 in.) $103 / 8$ and $105 / 8$ in. long, inserted between the joists in tro lines about equidistant from the headers and each other. The bridging was fastened to the joists by $6 \mathrm{~d}$ box nails. Two nails were driven through the outer joists into the ends of the bridging. Fastenings at the inner joists were made by one nail toenailed through the joists alternating with two nails driven through the joist into the ends of the bridging.

Flooring.-The flooring, $D$, was one piece of Douglas fir plywood, moisture-resistant type, $1 / 2$ in. thick, $8 \mathrm{ft} 0 \mathrm{in}$. long, and $3 \mathrm{ft} 113 / 4 \mathrm{in}$. wide. It was fastened by glue to the joists, headers, and bridging, which had been coated with the glue mixture. 'There were also three $4 d$ finishing nails driven through the flooring into each header, spaced approximately 1 ft 9 in. apart.

Ceiling.-The ceiling, $E$, was one piece of Douglas fir plywood, exterior type, $5 / 16$ in. thick, $8 \mathrm{ft} 0 \mathrm{in}$. long, and $3 \mathrm{ft} 113 / 4$ in. wide. It was fastened by glue to the joists, headers, and bridging, which had been coated with the glue mixture. There were also three th finishing nails driven through the ceiling into each header, spaced approximately $1 \mathrm{ft} 9 \mathrm{in}$. apart.

$I I$ alf splines.-Ialf splines, $F$, were Douglas fir, $25 / 32$ by $21 / 2$ in. (nominal 1 by 3 in.) $8 \mathrm{ft}$
0 in. long. The half splines were inserted between the flooring and ceiling after the flooring and ceiling were attached to the joists, header's, and bridging. The half splines were fastened in place by $6 \mathrm{~d}$ box nails driven through the flooring and ceiling and spaced approximately 6 in. apart.

\section{Transverse Load}

The results of the transverse load on floor specimens $D . T-T 1, T \Omega$, and $T .3$ are given in table 8 and in figure 33 . The transverse loads were applied to the upper face.

TABLF 8.-Structural properties of floor $D X$ [Weight, based on face area: $3.31 \mathrm{lb} / \mathrm{ft}^{2}$ ]

\begin{tabular}{|c|c|c|c|c|c|}
\hline \multicolumn{2}{|c|}{$\begin{array}{l}\text { Transverse load; } \\
\text { span, } 7 \mathrm{ft} 6 \text { in. }\end{array}$} & \multicolumn{2}{|c|}{$\begin{array}{l}\text { Concentrated load; } \\
\text { disk, diam } 1 \text { in. }\end{array}$} & \multicolumn{2}{|c|}{$\begin{array}{c}\text { Impact load; span, } \\
7 \mathrm{ft} 6 \text { in.; } \\
\text { sandbag, } 60 \mathrm{lb}\end{array}$} \\
\hline \multirow[t]{2}{*}{ Specimen } & $\begin{array}{c}\text { Maximum } \\
\text { load }\end{array}$ & Specimen & $\underset{\text { load }}{\text { Maximum }}$ & Specimen & $\begin{array}{c}\text { Maximum } \\
\text { loal }\end{array}$ \\
\hline & $l b / f t^{2}$ & & $l b$ & & $f t$ \\
\hline$T 1$ & 323 & $P 1 \ldots$ & $\mathrm{e} 1,000$ & I1. & ь 10,0 \\
\hline T2 & 320 & $P 2$ & в 1,000 & $12 \ldots$ & b 10.0 \\
\hline & 320 & $P 3_{-} \ldots$ & B1,000 & $I S_{\ldots} \ldots$ & 10.0 \\
\hline Average - & 321 & Average & 1,000 & Average. & 10.0 \\
\hline
\end{tabular}

specimen undamaged. Tést discontinued.

b No visible failure. Test discontinued.

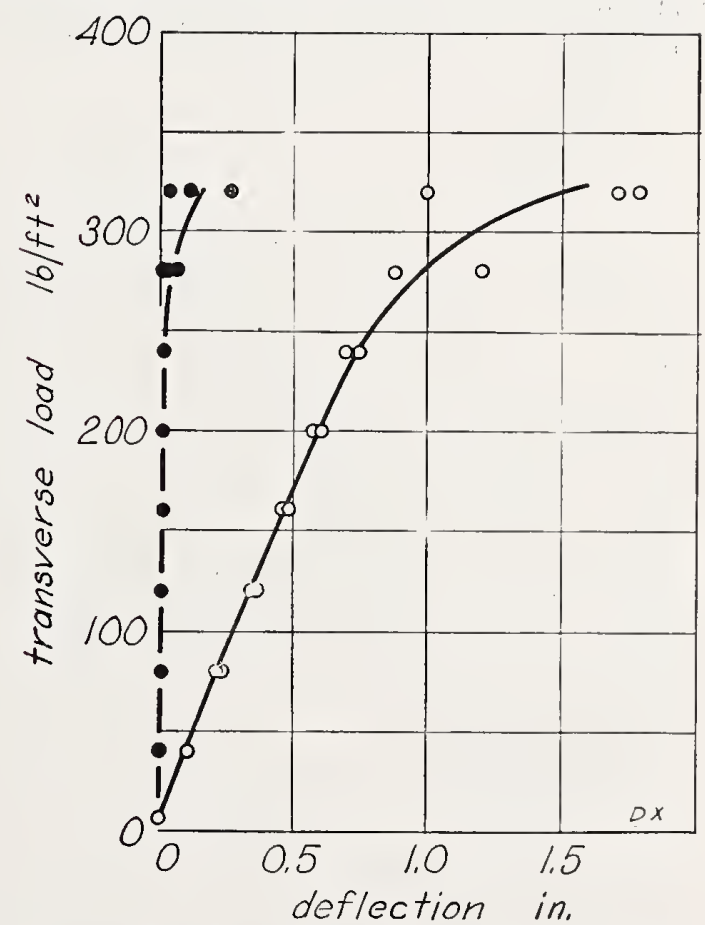

Figure 33.-Transverse load on floor D.T.

Ioad-deflection (open circles) and load-set (solid circles) results tor specimens $D X-T 1, T 2$, and $T 3$ on the span $T$ it $(i$ in. The load (pounds per square foot) is the total load divided by the product of the span and width of the specinlint. 
The speed of the movable head of the testing machine was adjusted to $0.15 \mathrm{in.} / \mathrm{min}$.

Loud noises, apparently due to glue failure, were first heard in specimens $T 1, T \%$, and $T \%$, at a load of 277,255 , and $293 \mathrm{lb} / \mathrm{ft}^{2}$, respectively. Under maximum load, $T 1$ failed in the glue joint between top face and one end plate; the bottom face of $T \%$ buckled; and one half spline broke in tension under a loading roller in T3. Examination after tests showed a tensile failure in one spline, a compressive failure in the other spline and in two joists, and horizontal shear in one joist of $7 ' 1$.

The middle joist of $T O$ failed both in tension and in horizontal shear. One spline failed in tension under a loading roller ; two joists had horizontal shear failures; and the plywood had separated from the joists in T3.

\section{Concentrated Load}

The results of the concentrated load on specimens $D I^{-}-P 1, P 2$, and $P 3$ are given in table 8 and in figure 34 .

The concentrated load was applied to specimens $D Y-P 1, P 2$, and $P 3181 / 2$ in. from one edge and $18 \mathrm{in.}$ from one end.

After the concentrated load had been applied and removed, the set in specimen $D X-P 1$ was 0.034 in.; in $P 2,0.043$ in.; and in $P 3,0.050$ in. No other effects were observed.

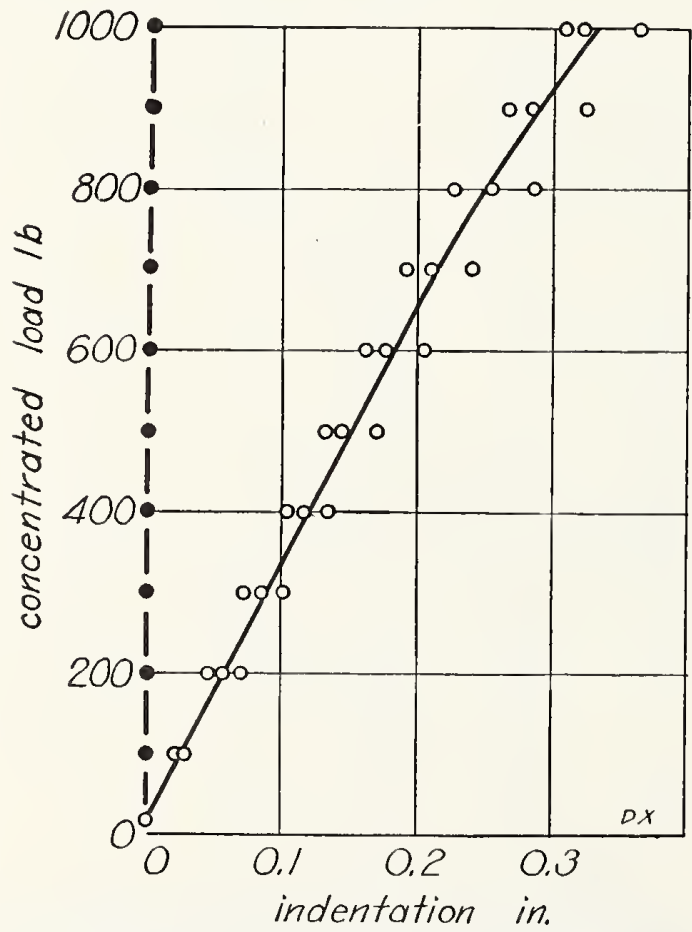

Figure 34-Concentrated load on floor DX.

Load-indentation (open circles) and load-set (solid circles) results for specimens $D X^{-}-P_{1}, P 2$, and $P 3$.

\section{Imipact Load}

The results of the impact-load test on specimens $D X-I 1, I 2$, and $I 3$ are shown in table 8 and in figure 35 .

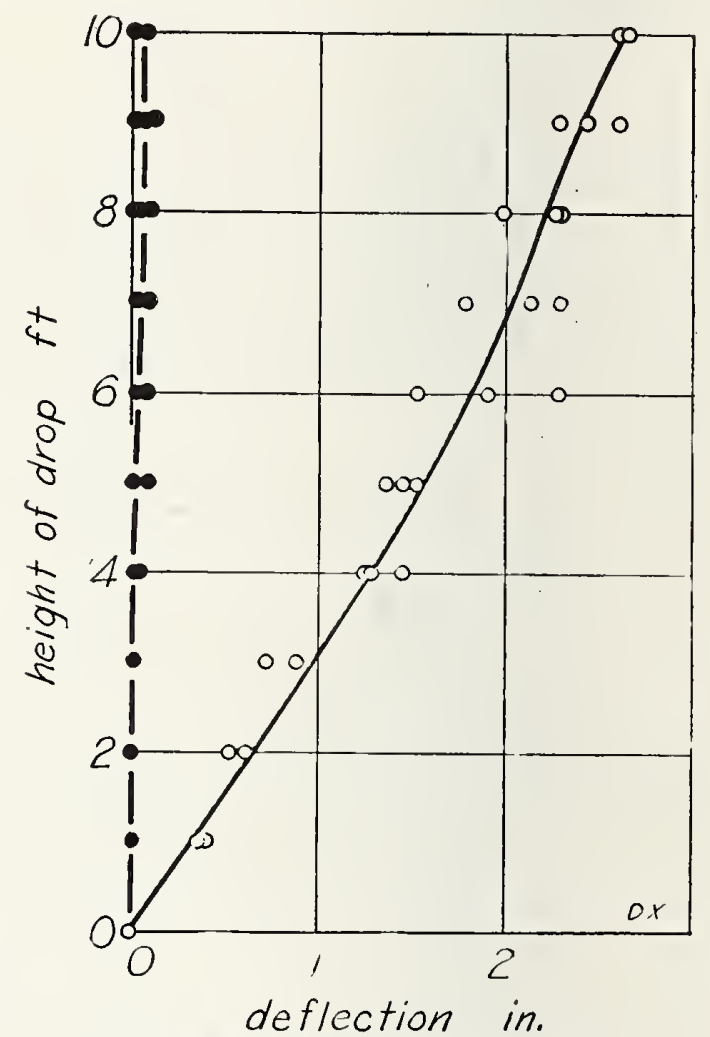

FigURE 35.-Impact load on floor $D X$.

Height of drop-deflection (open circles) and height of dropset (solid circles) results for specimens $D X-11,12$, and 13 , on the span $7 \mathrm{ft} 6$ in.

$\Lambda \mathrm{fter}$ a drop of $4.0 \mathrm{ft}$ on $I 1,2.5 \mathrm{ft}$ on $I 2$, and $3.5 \mathrm{ft}$ on $I 3$, a noise was heard, apparently due to glue failure. No other effects were observed. After a drop of $10 \mathrm{ft}$, the set in $I 1$ was $0.013 \mathrm{in.}$; in $12,0.078 \mathrm{in}$. ; and in 13 , $0.075 \mathrm{in.}$

\section{FLOOR $D Y$}

\section{Sponsor's Statement}

Floor $D Y$ was designed as a long-span floor panel and consisted of lightweight wood joists and solid bridging with plywood as both faces, the faces being fastened by glue. The faces were subjected to a pressure of $86 \mathrm{lb} / \mathrm{in}^{2}{ }^{2}$ on the joist, header, and bridging surfaces for a period of 35 minutes while the glue hardened. 'To hasten the time of set, the temperature of air surrounding work in the presses was raised to $141^{\circ} \mathrm{F}$ by panels of infrared light. The specimens were not painted. 
The price of this construction in Washington, D. C. as of July 1937 was $\$ 0.38 / \mathrm{ft}^{2}$.

\section{(a) Description of Specimens}

The floor specimens $D Y$, shown in figure 36 , were $12 \mathrm{ft} 6$ in. long, $3 \mathrm{ft} 113 / 4$ in. wide, and $65 / 16$ in. deep. Each specimen had five joists, .1 , fastened to header's, $B$. There were five lines of solid bridging, $C$, extending between the joists. Flooring, $D$, and ceiling, $E$, each consisted of two pieces of plywood. Joints in the plywood were butt joints, placed orer the centers of lines of bridging. Splice strips, $F$, overlapped the joint on the flooring, and splice strips, $G$, the joint in the ceiling. Half splines, $H$, were inserted between the faces at the sides.

Joists.-The joists, A, were Douglas fir, $25 / 32$ by $5 \frac{1}{2}$ in. (nominal 1 by 6 in.) $12 \mathrm{ft} 4 \frac{1}{2}$ in. long, spaced $111 / 8$ and $113 / 8$ in. apart, as shown in figure 36 .

Headers.-Headers, $B$, were Douglas fir, $25 / 32$ by $51 / 2$ in. (nominal 1 by 6 in.) $3 \mathrm{ft} .101 / 4$ in. long, extending across the ends of the joists. The headers were fastened to the joists by $6 \mathrm{~d}$ box nails driven through the headers into the ends of the joists, three nails into each joist end.

Bridging.-The solid bridging, $C$, was Douglas fir, $25 / 32$ by $5 \frac{1}{2}$ in. (nominal 1 by 6 in.) $103 / 8$ and $105 / 8$ in. long, inserted between the joists in five lines, spaced as shown in figure 36. 'The bridging was fastened to the joists by $6 \mathrm{~d}$ box nails. Three nails were driven through the outer joists into the ends of the bridging. Fastenings at the inner joists were made by one nail toenailed through the joists alternating with two nails driven through the joists into the ends of the bridging.

Flooring.-The flooring, $D$, was two pieces of Douglas fir plywood, moisture-resistant type, $1 / 2$ in. thick and $3 \mathrm{ft} 113 / 4$ in. wide. One piece was $8 \mathrm{ft} 0$ in. long and the other $4 \mathrm{ft} 6 \mathrm{im}$. long. They were fastened by glue to the joists, headers, and bridging, which had been coated with the glue mixture. Three $4 d$ finishing nails, spaced approximately $1 \mathrm{ft} 9 \mathrm{in}$. apart, were driven through the flooring into each header.

Ceiting.-The ceiling, $E$, was two pieces of Douglas fir plywood, exterior type, $5 / 16$ in. thick and $3 \mathrm{ft} 113 / 4$ in. wide. One piece was 8 $\mathrm{ft} 0$ in. long and the other $4 \mathrm{ft} 6 \mathrm{in}$. long. They were fastened by glue to the joists, headers, and bridging, which had been coated with the glue mixture. Three $4 d$ finishing nails, spaced approximately $1 \mathrm{ft} 9$ in. apart, were driven through the ceiling into each header. The joint was over the center of a line of bridging, and was placed at the oppo-

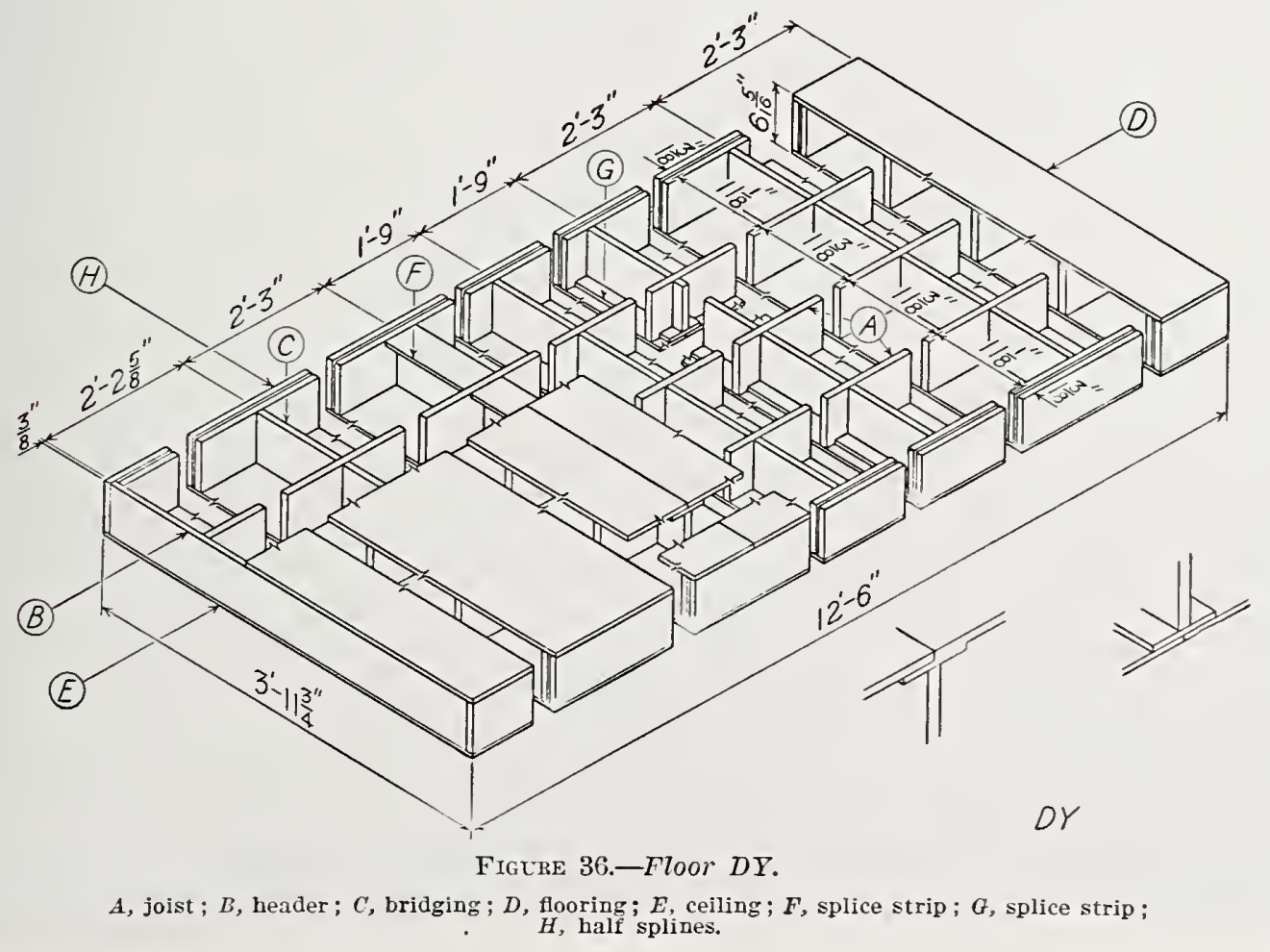


site end of the specimen from the joint in the flooring.

Splice strips.-Splice strips, $F$ and $G$, were Douglas fir plywood, moisture-resistant type, $3 / 8$ in. thick, 4 in. wide, and $103 / 8$ and $105 / 8$ in. long. The strips were placed symmetrically over a line of bridging, which had been cut back $3 / 8$ in. Each splice strip was fastened by three $3 d$ box nails, driven through the strip into the bridging. Overlapping edges of flooring and ceiling were fastened by glue. Splice strips, $F$, joined the flooring pieces and splice strips, $G$, the ceiling.

II alf splines.-Half splines, $H$, were Douglas fir, $25 / 32$ by $51 / 2$ in. (nominal 1 by 6 in.) 12 ft 6 in. long. ${ }^{\bar{T}}$ The half splines were inserted between the flooring and ceiling after the flooring and ceiling were attached to joists, headers, and bridging. The half splines were fastened in place by $6 \mathrm{~d}$ box nails driven through the flooring and ceiling and spaced approximately 6 in. apart.

\section{Transverse Load}

Floor specimen $D Y-T 1$ during the transverse-load test is shown in figure 37 . The results of the transverse-load test on floor specimens $D Y-T 1, T 2$, and $T 3$ are given in table 9 , and in figure 38 .

TABLE 9.-Structural properties of floors $D Y^{+}$and $D Y a$ [Weight, based on face area: $4.55 \mathrm{lb} / \mathrm{ft}^{2}$ ]

\begin{tabular}{|c|c|c|c|c|c|c|}
\hline \multirow{2}{*}{$\begin{array}{c}\text { Construe- } \\
\text { tion } \\
\text { symbol }\end{array}$} & \multicolumn{2}{|c|}{$\begin{array}{l}\text { Transverse } \\
\text { load; span, } \\
12 \text { ft } 0 \text { in. }\end{array}$} & \multicolumn{2}{|c|}{$\begin{array}{l}\text { Concentrated } \\
\text { load; disk } \\
\text { diam, } 1 \mathrm{in.}\end{array}$} & \multicolumn{2}{|c|}{$\begin{array}{c}\text { Impact load; } \\
\text { weight of } \\
\text { sandbag, } 60 \mathrm{lb}\end{array}$} \\
\hline & $\begin{array}{c}\text { Speci- } \\
\text { men }\end{array}$ & $\begin{array}{l}\text { Maxi- } \\
\text { mum } \\
\text { load }\end{array}$ & $\begin{array}{c}\text { Speci- } \\
\text { men }\end{array}$ & $\begin{array}{l}\text { Maxi- } \\
\text { mum } \\
\text { load }\end{array}$ & $\begin{array}{c}\text { Speci- } \\
\text { men }\end{array}$ & $\begin{array}{l}\text { Maxi- } \\
\text { mumi } \\
\text { load }\end{array}$ \\
\hline \multirow{4}{*}{ DY $\ldots$} & & $l b / f t^{2}$ & & $l b$ & & $f t$ \\
\hline & $\mathrm{T} 1$ & 329 & P1 & a 1,000 & 11 & -10.0 \\
\hline & $\mathrm{T} 2$ & 348 & $\mathrm{P} 2$ & a 1,000 & 12 & $\triangle 10.0$ \\
\hline & T3 & 377 & $\mathrm{P} 3$ & 800 & I3 & $\therefore 10.0$ \\
\hline \multirow[t]{2}{*}{ Average. } & -- & 351 & & & & 10.0 \\
\hline & T1 & 440 & & & & \\
\hline \multirow[t]{2}{*}{ DYa..... } & $\mathrm{T} 2$ & 521 & & & & \\
\hline & T3 & 375 & & & & \\
\hline Average & & 445 & & & & \\
\hline
\end{tabular}

* Test discontinued. No failure.

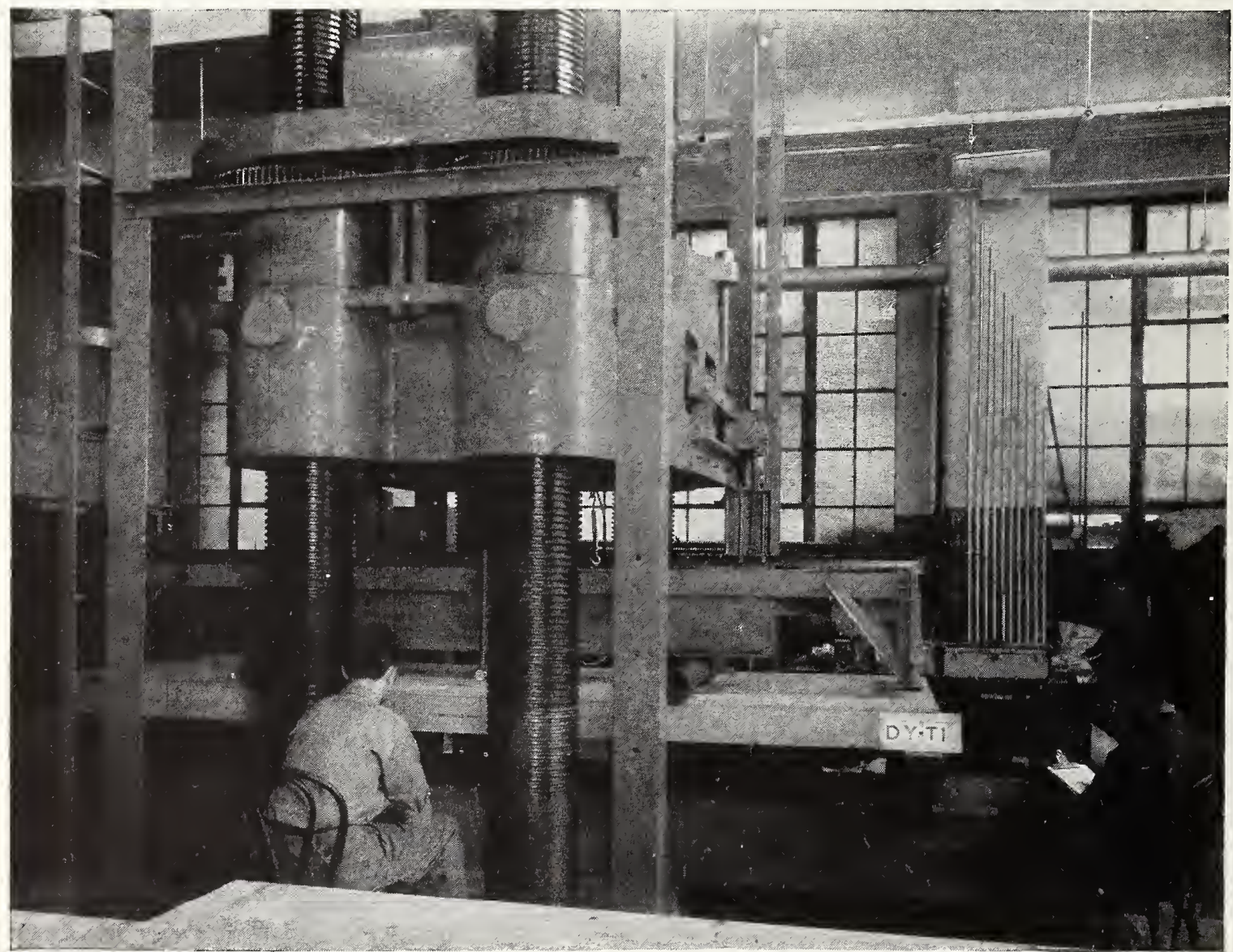

FIGURE 37.-Floar speeimen DY-T1 during transverse load test. 


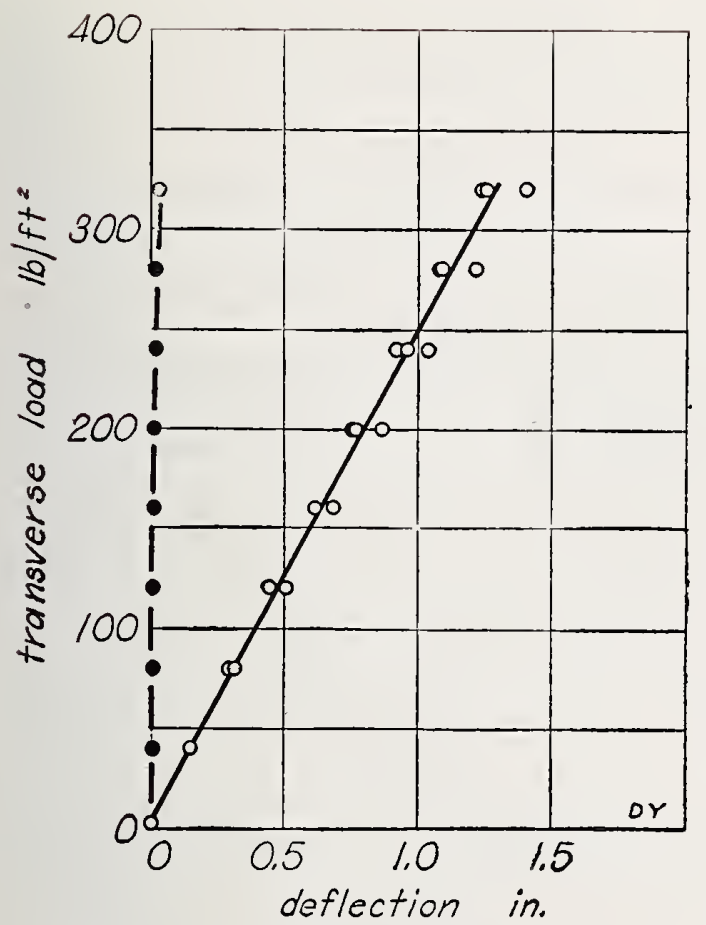

Figure 3S.-Transverse load on floor $D Y$.

Load-deflection (open circles) and load-set (solid circles) results for speeimens $D Y-T 1, T 2$, and $T 3$, on the span $12 \mathrm{ft} 0$ in. The load (pounds per square foot) is the total load dirided by the product of the span and the width of the specimen.
The speed of the movable head of the testing machine was adjusted to $0.21 \mathrm{in.} / \mathrm{min}$.

Under the maximum load, specimens T1, T\&, and $T 3$ failed in tension at the transverse butt splice in the ceiling plywood as shown in figure 39. Examination after test disclosed a failure in one half spline, horizontal shear failure in four joists, and tensile failure in two joists of T1. Three joists failed by horizontal shear in T2. One half spline and one joist broke in tension, and three joists failed in horizontal shear in $T$.

\section{Concentrited Load}

The results of the concentrated load on specimens $D Y-P 1, P 2$, and $P 3$ are given in table 9 and in figure 40.

The concentrated load was applied $18 \mathrm{in.}$ from one edge and $18 \mathrm{in}$. from one end of specimens $D Y-P 1, P Q$, and $P$ 3. Under a load of $800 \mathrm{lb}$, the plywood cracked in specimen P3. After a load of $1,000 \mathrm{lb}$ had been applied, the set in $P 1$ was 0.033 in.; and in $P Q, 0.035$ in. No other effects were observed.

\section{INTPACT LOAD}

The results of the impact-load test on specimens $D Y-I 1, I 2$, and $I 3$ are shown in table 9 and in figure 41 .

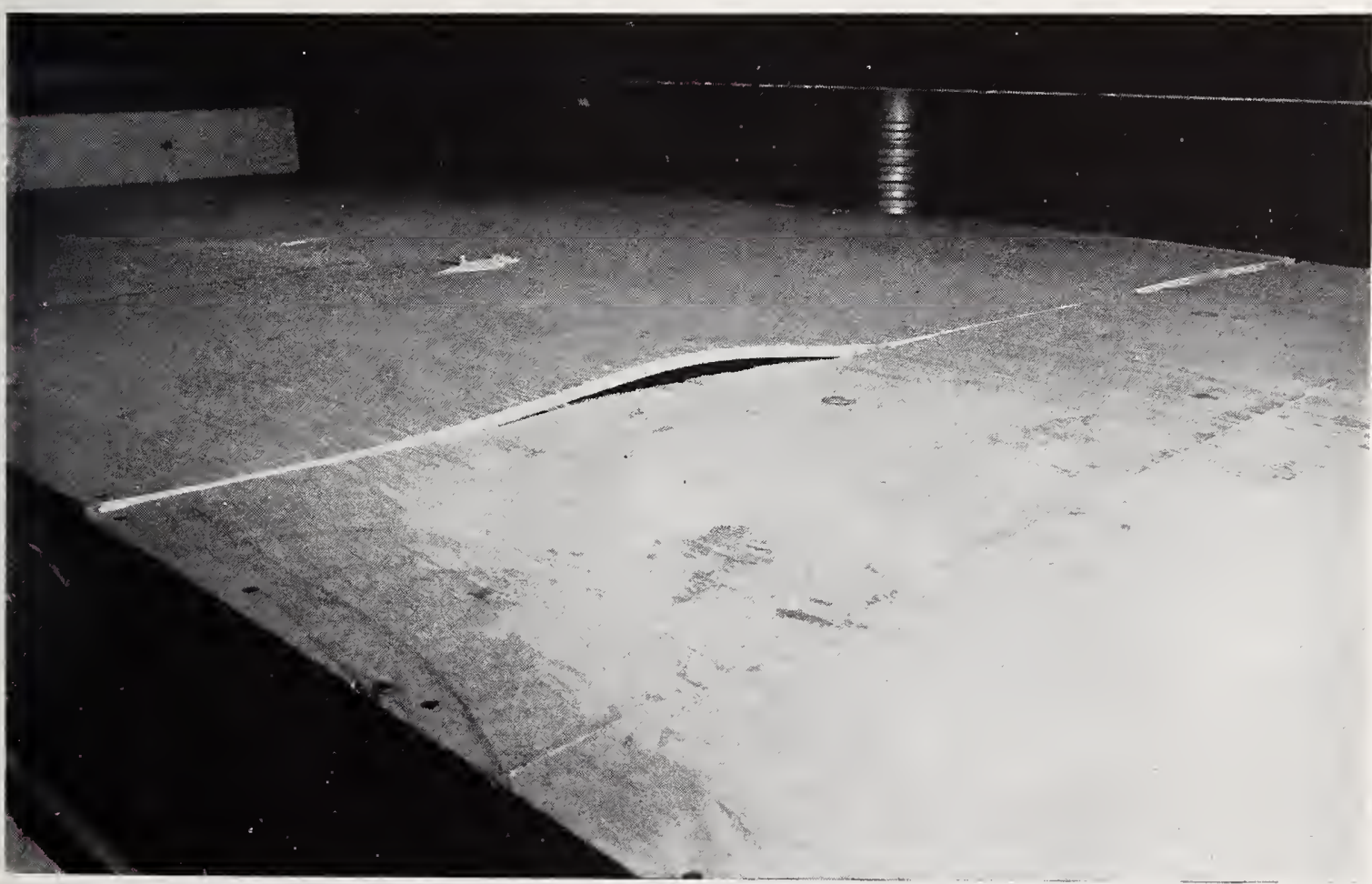

Figure 39.-Failure in butt joint of plywood ceiling of floor speeimen DY-T1. 


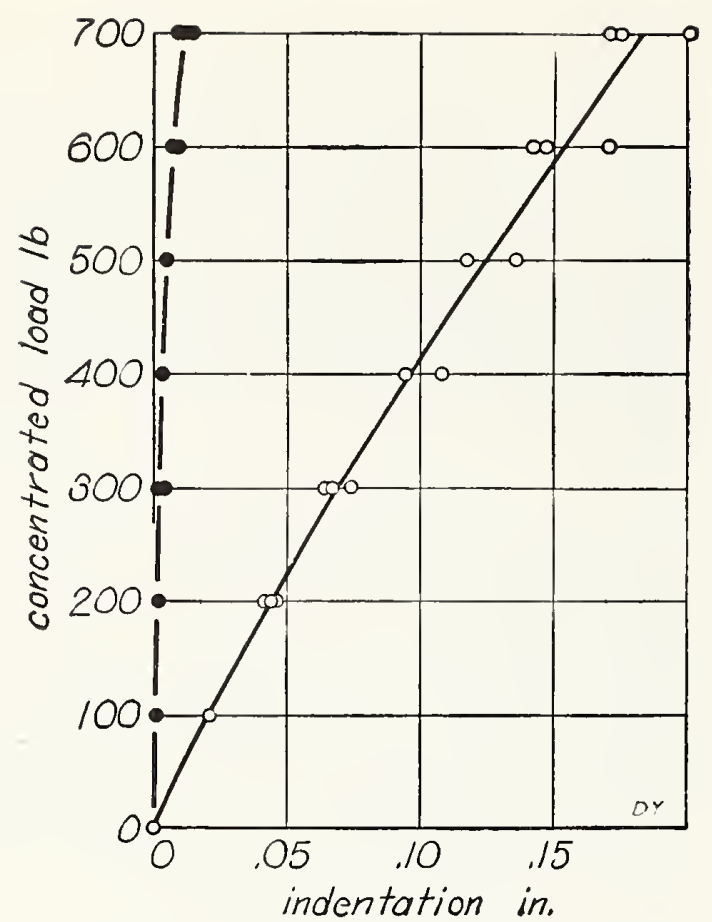

FIGUre 40.-Concentrated load on floor $D Y$.

Load-indentation (open circles) and load-set (solid circles) results for specimens $D Y-P 1, P 2$, and $P 3$.

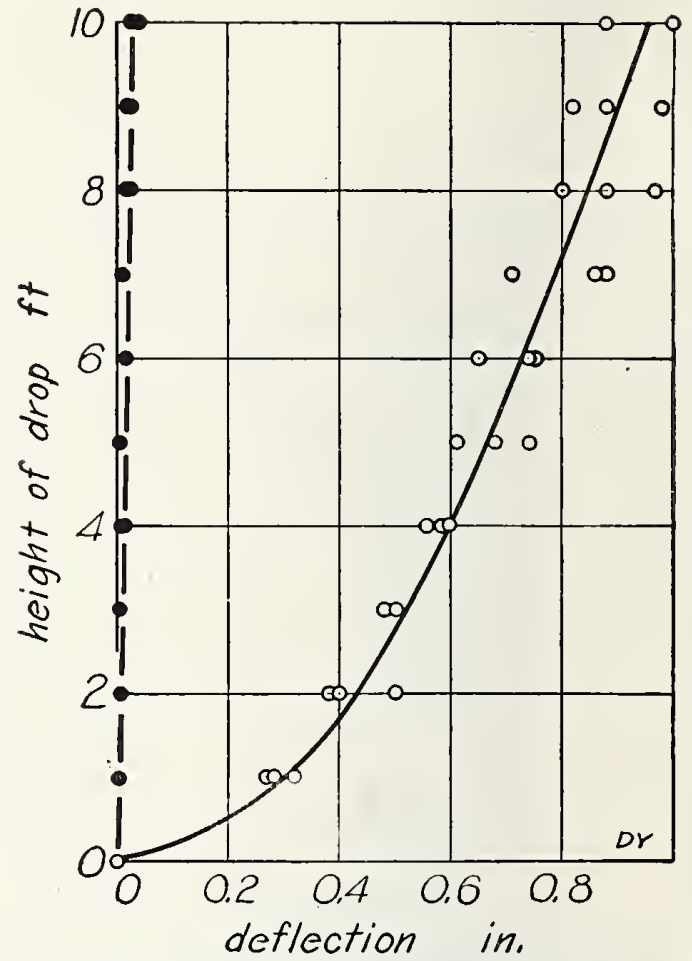

Figure 41.-Impact load on floor $D Y$.

Height of drop-deflection (open circles) and height of dropset (solid circles) results for specimens $D Y-I 1, I 2$, and $I 3$,
on the span 12 it 0 in.

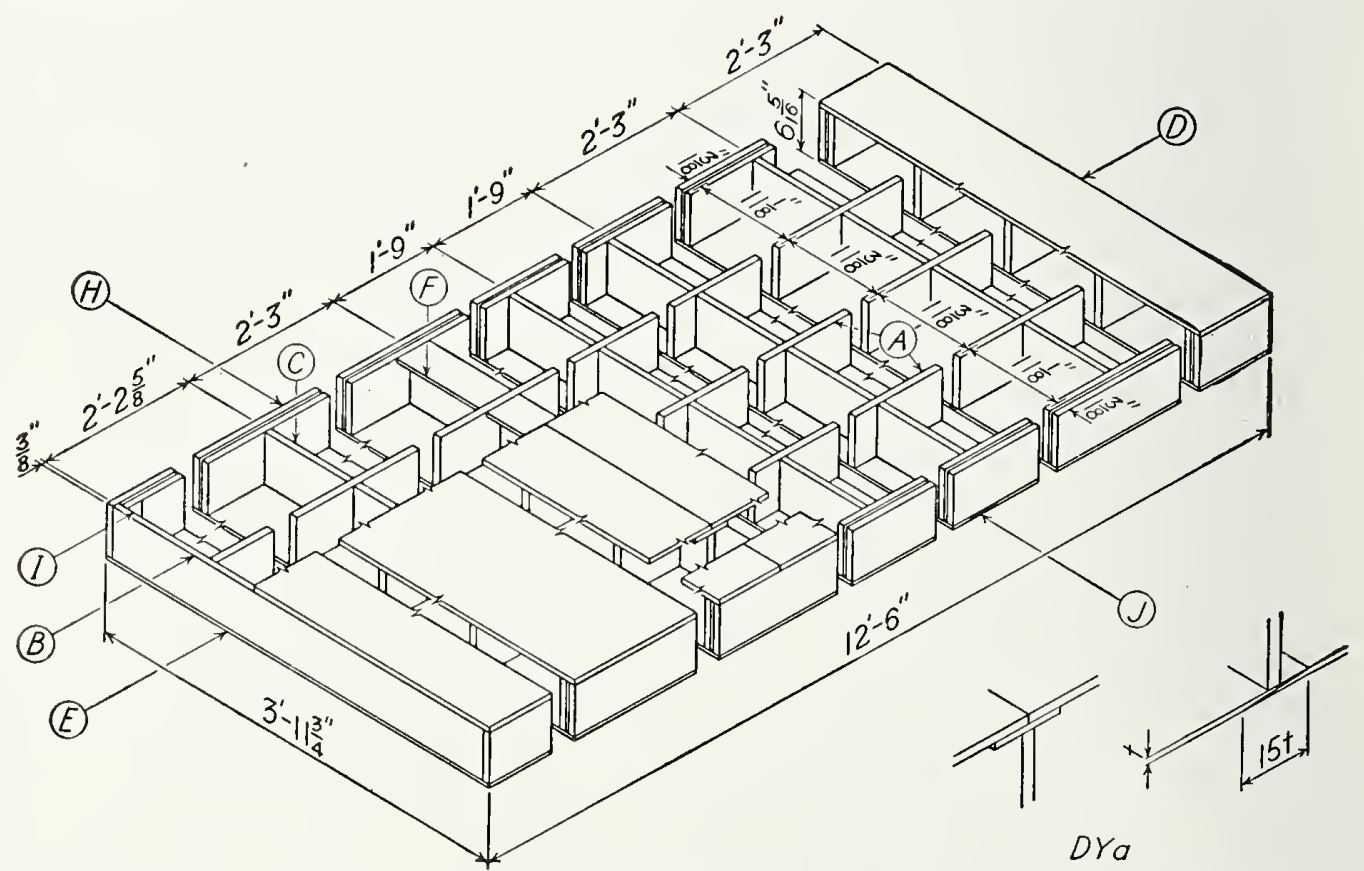

Figure 42.Floor $D \bar{Y} a$.

$A$, joist; $B$, header, $O$, bridging; $D$, flooring; $E$, ceiling; $F$, splice strip ; $H$, half splines ; $I$, blocks; $j$, searf joint of ceiling pieces. 
After the 10-ft drop on each specimen, the set in 11 was $0.032 \mathrm{in}$.; in $I 2,0.019 \mathrm{in}$; and in I3, 0.019 in. No other effects were observed.

\section{FLOOR $D T a$}

\section{Sponson`s Statement}

\section{(a) Description of Specimens}

The floor specimens $D Y a$, shown in figure 42 , were like floor specimens $L Y$, except that the ceiling pieces were joined with a scarf joint, $J$, slope 1 in 15 , instead of a butt joint, and splice strips, $G$, were omitted. The joint between the ceiling pieces was made before the ceiling was applied to the framing members. The orerlapping surfaces were coated with glue, and subjected to heat and pressure while the glue hardened. Triangular blocks, I, were fastened in the four comers of the frame to strengthen the fastenings at these points.

Blocks.-Blocks, I. were Douglas fir, 15/ in. by $15 / 8$ in., beveled face, $51 / 2$ in. long, fastened with glue and two $3 d$ box nails to each block.

\section{(b) Comments}

The floors of a house consist of panels, designed to rest on wood sills or plates, and are joined together by full size wood splines. The flooring may be finished with stain and varnish, or overlaid with hardwood flooring or other suitable flooring material. The ceiling is usually finished with paint.

After the transverse-load tests of the $D Y$ specimens had been made, it was pointed out that if there had been scarf joints in the ceiling, the transverse strength would have been greater. The sponsor fumished the $D Y$ a specimens having scarf joints to enable the difference in strength to be determined.

\section{Transverse Lohd}

The results of the transverse-load test on floor specimens $D Y a-T 1 . T 2$, and 73 are given in table 9 and in figure 43.

The speed of the movable head of the testing machine was adjusted to $0.21 \mathrm{in.} / \mathrm{min}$.

Loud noises, probably caused by the failure of the glue joints, were first heard at a load of 360,240 , and $319 \mathrm{lb} / \mathrm{ft}^{2}$ for specimens $T 1$, T2, and T3, respectively. Under the maximum load, the bottom faces of specimens $T 1$ and T'3 buckled. One spline of specimen $T 1$ failed in tension and one spline of specimen $T 2$ failed in horizontal shear. Examination after test

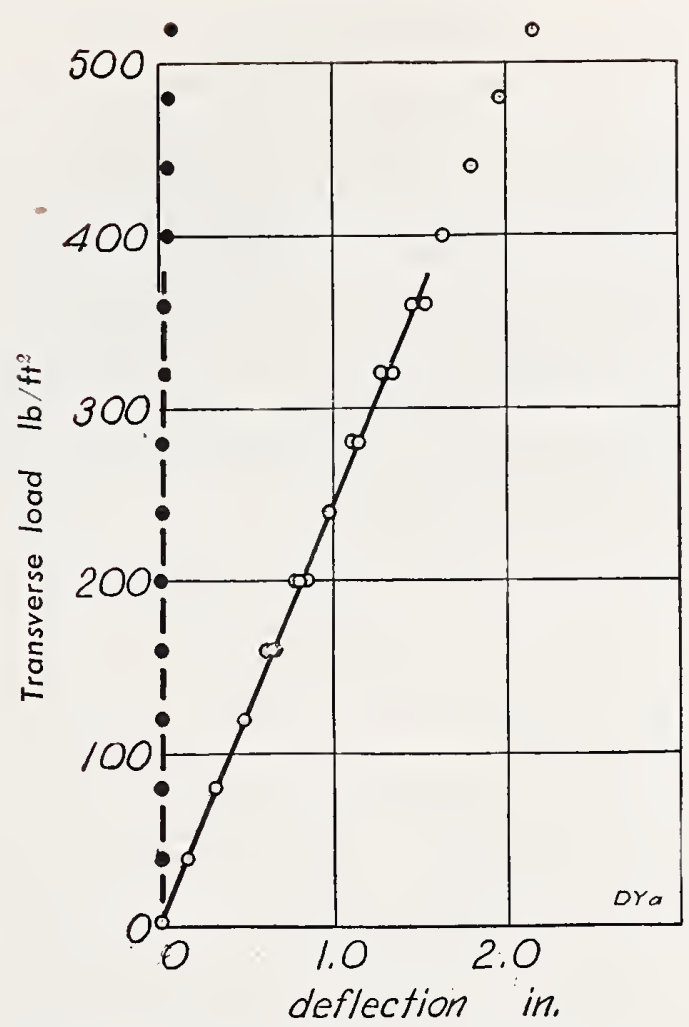

Figure 43.-Transterse load on floor DYa.

Load-deflection (open circles) and load-set (solid circles) results for specimens $D Y a-T^{\prime} 1$, $T^{\prime} 2$, and $T^{\prime} 3$, on the span $12 \mathrm{ft} 0 \mathrm{in}$. The load (pounds per square foot) is the total load divided by the product of the span and the width of the specimen.

disclosed separation of top face from the joists in specimens T1, TS, and T3. Three joists failed in compression and the two joists and the other spline failed in tension in T1. The other spline and two joists failed in horizontal shear; two joists failed in tension; and two joists failed in compression in T\%. One spline and two joists broke in tension; two joists failed in compression; and one joist failed in horizontal shear in $T 3$.

The scarf joints in the ceiling of $T 1$ and T3 did not fail although the deflection at midspan was 7.9 and $6.0 \mathrm{in}$. at the time the test was stopped after the maximum load had been reached. When the deflection at midspan was 5 in. in $T ?$ and some time after the maximum load had been reached, the scarf joint failed. There was no failure in the scarf joint for any of these three specimens at the maximum transverse load.

The data of table 9 show that the floor specimens subjected to transverse load that had scarf joints were more than 26 percent stronger than those that had butt joints in the ceiling. 


\section{ROOF DZ}

\section{Sponsor's Statement}

Roof $D Z$ consisted of lightweight wood joists and solid bridging with plywood as both faces, the faces being fastered by glue. The faces were subjected to a pressure of $86 \mathrm{lb} / \mathrm{in} .^{2}$ on the joists, header, and bridging surfaces for a period of 35 minutes, while the glue hardened. To hasten the time of set, the temperature of air surrounding work in the presses was raised to $141^{\circ} \mathrm{F}$ by panels of infrared light. The specimens were without roofing material and were not painted.

The price of this construction in Washington, D. C. as of July 1937 was $\$ 0.41 / \mathrm{ft}^{2}$.

\section{(a) Description of Specimens}

The roof specimens $D Z$, shown in figure 44 , were $12 \mathrm{ft} 6 \mathrm{in}$. long, $3 \mathrm{ft} 113 / 4 \mathrm{in}$. wide, and $41 / 8$ in. deep. Each specimen had five joists, $A$, fastened to lieaders, $B$. There were tive lines of solid bridging, $C$, extending between the joists. Sheathing, $D$, and ceiling, $E$, each consisted of two pieces of plywood. Joints in the plywood were butt joints, placed over the centers of lines of bridging. Splice strips. $F$, overlapped the joint in sheathing. Splice strips, $c^{r}$, overlapped the joint in the ceiling.
Half splines, $I I$, were inserted between the faces at the sides.

Joists.-The joists, $A$, were Douglas fir, $25 / 32$ by $31 / 2$ in. (nominal 1 by 4 in.) $12 \mathrm{ft}$ $41 / 2$ in. long, spaced $111 / 8$ and $113 / 8$ in. apart as shown in figure 44.

IHeaders.-Headers, I;, were Douglas fir, $25 / 32$ by $31 / 2$ in. (nominal 1 by 4 in.) $3 \mathrm{ft} \mathrm{101/4}$ in. long, extending across the ends of the joists. The headers were firstened to the joists by $6 \mathrm{~d}$ box mails driven through the headers into the ends of the joists, two nails into each joist end.

Bridging.-The solid bridging, $C$, was Douglas fir, $25 / 32$ by $31 / 2$ in. (nominal 1 by 4 in.) $103 / 8$ and $10 \% /$ in. long, inserted between the joists in fire lines, spaced as shown in figure 44. The bridging was fastened to the joists by $6 d$ box nails. Two nails were driven through the outer joists into the ends of the bridging. Fastenings at the inner joists were made by one nail toenailed through the joists alternating with two nails driven through the joists into the ends of the bridging.

Sheathing.-The sheathing, $D$, was two pieces of Douglas fir plywood. moisture-resistant type, $3 / 8 \mathrm{in}$. thick and $3 \mathrm{ft} 113 / 4 \mathrm{in}$. wide. One piece was $8 \mathrm{ft} 0 \mathrm{in}$. long and the other $4 \mathrm{ft} 6 \mathrm{in.} \mathrm{long.} \mathrm{They} \mathrm{were} \mathrm{fastened} \mathrm{by} \mathrm{glue}$ to the joists, headers. and bridging, which had been coated with the grlue mixture. There were

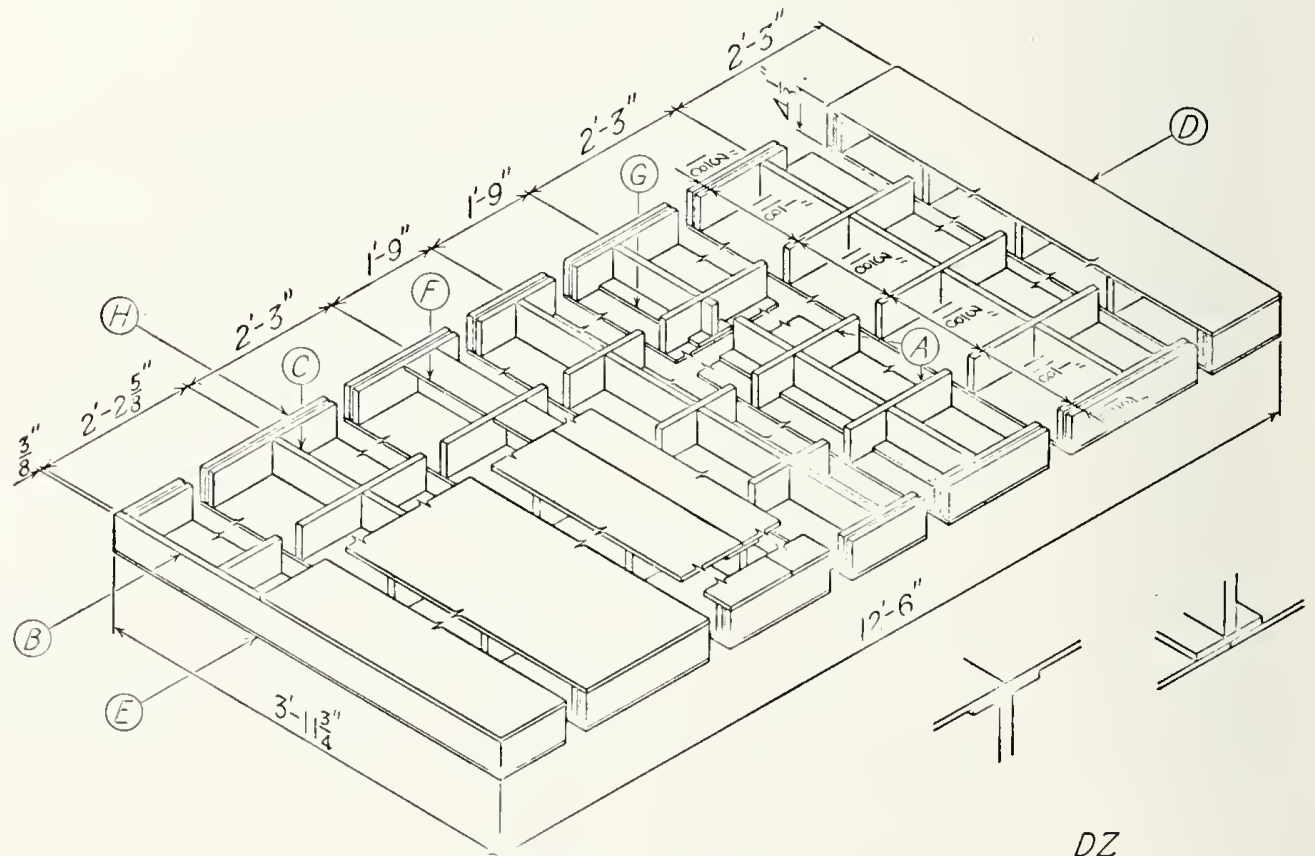

Figure 44.-Roof $D Z$.

$A$, joist; $l$, header; $C$, bridging; $D$, sheathing: $E$, ceiling; $F$, sheating splice strip ; $G$. ceiling splice strip; $I I$, hall spline. 
also three to finishing nails driven through the sheathing into each header, spacerl $1 \mathrm{ft} 9 \mathrm{in}$. apart. 'The joint was over the eenter of a line of bridging.

C'ciling.-The ceiling, $E$, was two pieces of Douglas fir plywood, moisture-resistant type, ${ }_{1}$ in. thick and $3 \mathrm{ft} 11 \% \mathrm{in}$. wirle. One piece was $8 \mathrm{ft} 0$ in. long and the other $4 \mathrm{ft} 6 \mathrm{in}$. long. They were fistened by glue to the joists, headlers, and bridging, which had been coated with the glue mixture. There were also three td finishing nails driven through the ceiling into each header, spacod 1 ft 9 in. apart. The joint was over the center of a line of bridging and was placed at the opposite end of the specimen from the joint in the sheathing.

splice strips.-Splice strips, $E$. and $G$, were Douglas fir plywood. moistme-resistant type, $3 / 8$ in. thick, $+\mathrm{in}$. wide, and $10 \% / \mathrm{s}$ in. long. 'The strips were placed srmmetrically over a line of bridging, which had been cut back $3, s$ in. Each splice strip was fastened by three 30 box nails, driven through the block into the bridining. The overtapping edges of sheathing and ceiling were fastened by glue. Splice strips, $F$. joined the sheathing pieces and splice strips, $G$. the ceiling.

II alf splines.-Half splines. $I I$. were Douglas fir, $25 / 32$ by 312 in. (nominal 1 by 4 in.) $12 \mathrm{ft}$ 6 in. long. The half splines were inserted between the sheathing and ceiling after the sheathing and ceiling were attached to the joists, headers, and bridging. The half splines were fastened in place by $6 \mathrm{~d}$ box nails driven through the sheathing and ceiling and spaced 6 in. apart.

\section{Thenasverse Load}

The results for the transverse load on roof specimens $D Z-T 1$. T2 and $T 3$, are given in table 10 and in figure 45.

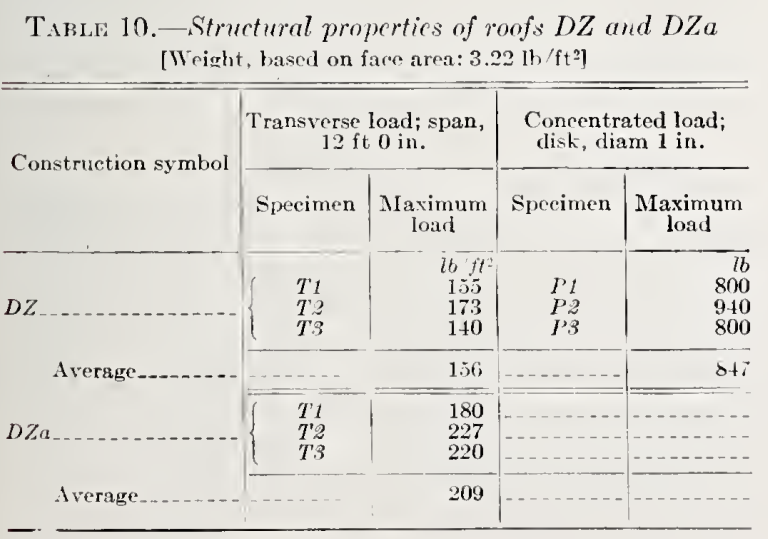

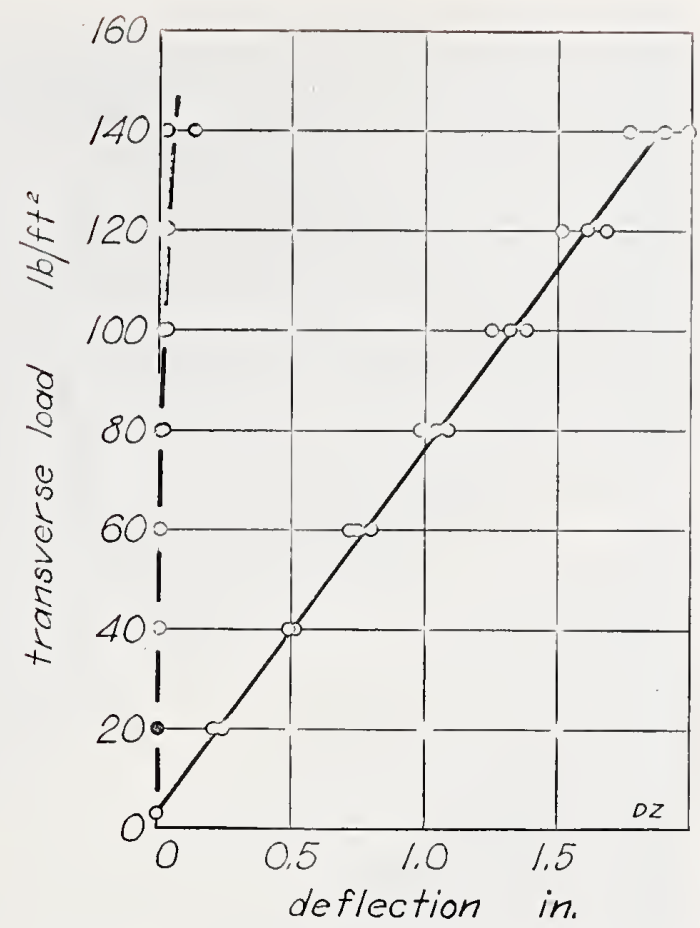

Figure 45.-Transverse load on roof DZ.

Loaldeflection (open circles) and load-set (soljd circles) results for specimens $D Z-T 1, T 2$, and $T 3$, on the span 12 110 in. The load (pommls per square foot) is the total lond divided by the protuct of the span and the width of the specimen.

The speed of the movable head of the testing machine was adjusted to $0.32 \mathrm{in} . / \mathrm{min}$.

Cnder the maximum load, the transverse joint in the ceiling plywood failed in tension in specimens $T \%, T ?$ and $T 3$, as shown in figure 46. In T', one half spline failed at a knot under the maximum load. Ifter test, examination disclosed horizontal shear failures in all joists of $T \%$. In TQ, one half spline failed in tension and in horizontal shear, and three joists failed in horizontal shear. Three joists of $T 3$ failed in horizontal shear.

\section{Concentrated Load}

The results of the concentrated loads on specimens DZ-P1. P., and P.3 are shown in table 10 and in figure 47 .

The concentrated load was applied to specimens $D Z-P 1, P:$, and $P 3,18$ in. from one end and 18 in. from one side. Under the maximum load, the disk pmiched through the plywood of each specimen. No other effects were observed. 


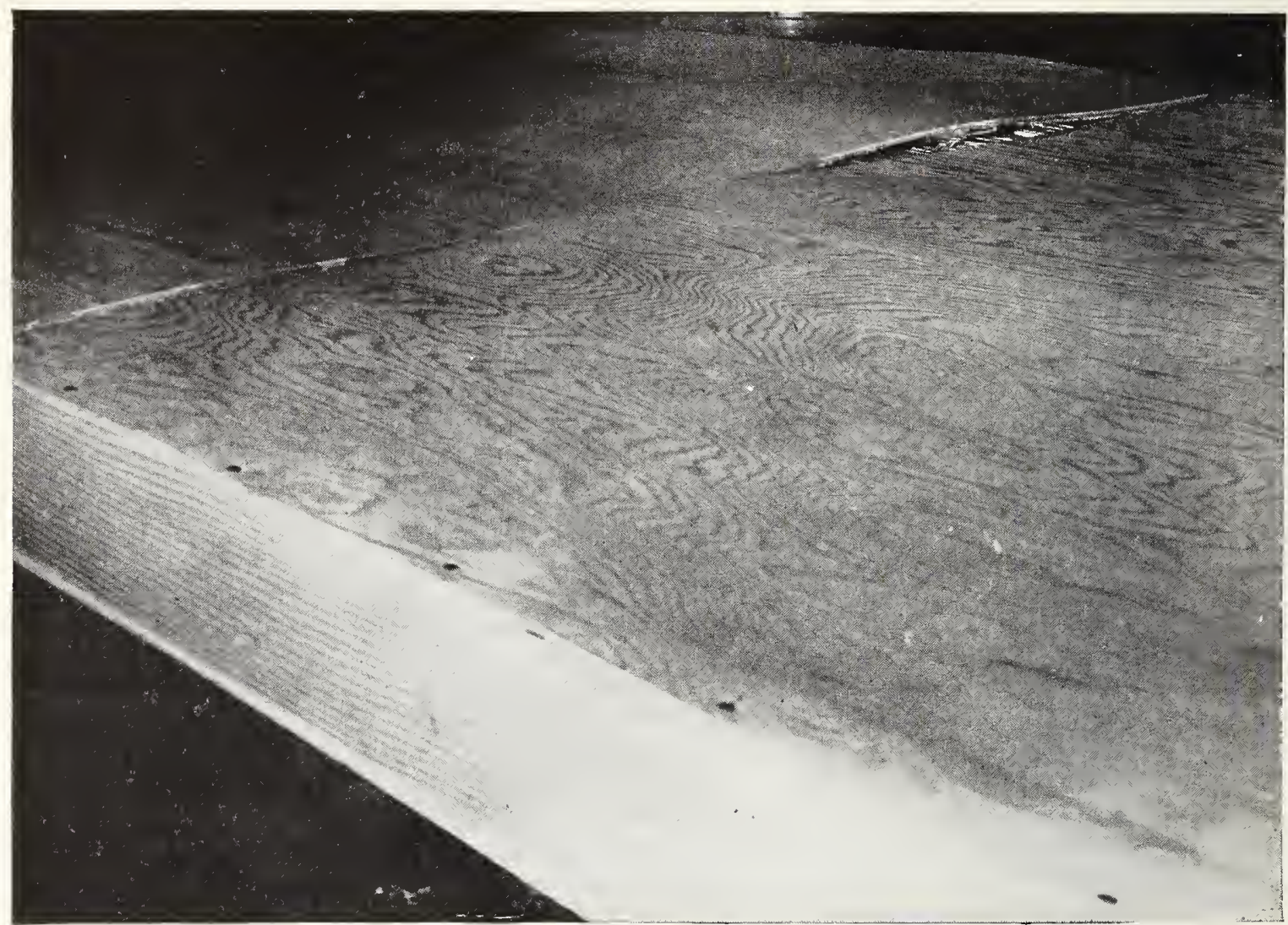

FIgURe 46.-Failure in butt joint of plywood ceiling of roof specimen DZ-T1.

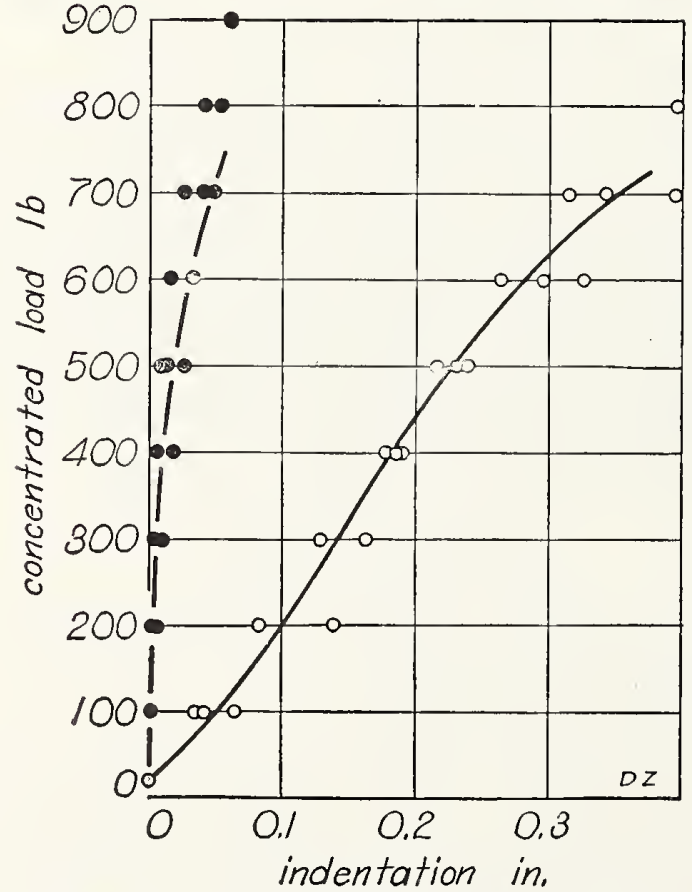

Figure 47.-Concentrated load on roof DZ.

Load-indentation (open circles) and load-set (solid circles) results for specimens $D Z-P_{1}, P_{2}$, and $P_{3}$.

\section{ROOF $D Z a$}

1. Sponsor's Statement

(a) Description of Specimens

The roof specimens $D Z a$, shown in figure 48 , were like roof specimens $D Z$, except that the ceiling pieces were joined with a scarf joint, 1 in 15 , instead of a butt joint, and splice strips, $G$, were omitted. The joint between the ceiling pieces was made before the ceiling was applied to the framing members. The overlapping surfaces were coated with glue and subjected to heat and pressure while the glue hardened.

\section{(b) Comments}

For flat-roof construction, the roof panels are similar to the specimens submitted for test. For pitched-roof construction, the ceiling face is omitted. In either case, the panels are joined by continuous plates along the eaves and fullsize wood splines between. The sheathing may be covered by any suitable type of roofing. The ceiling is usually finished with paint.

After the transverse tests of the $D Z$ specimens had been made, it was pointed out that 


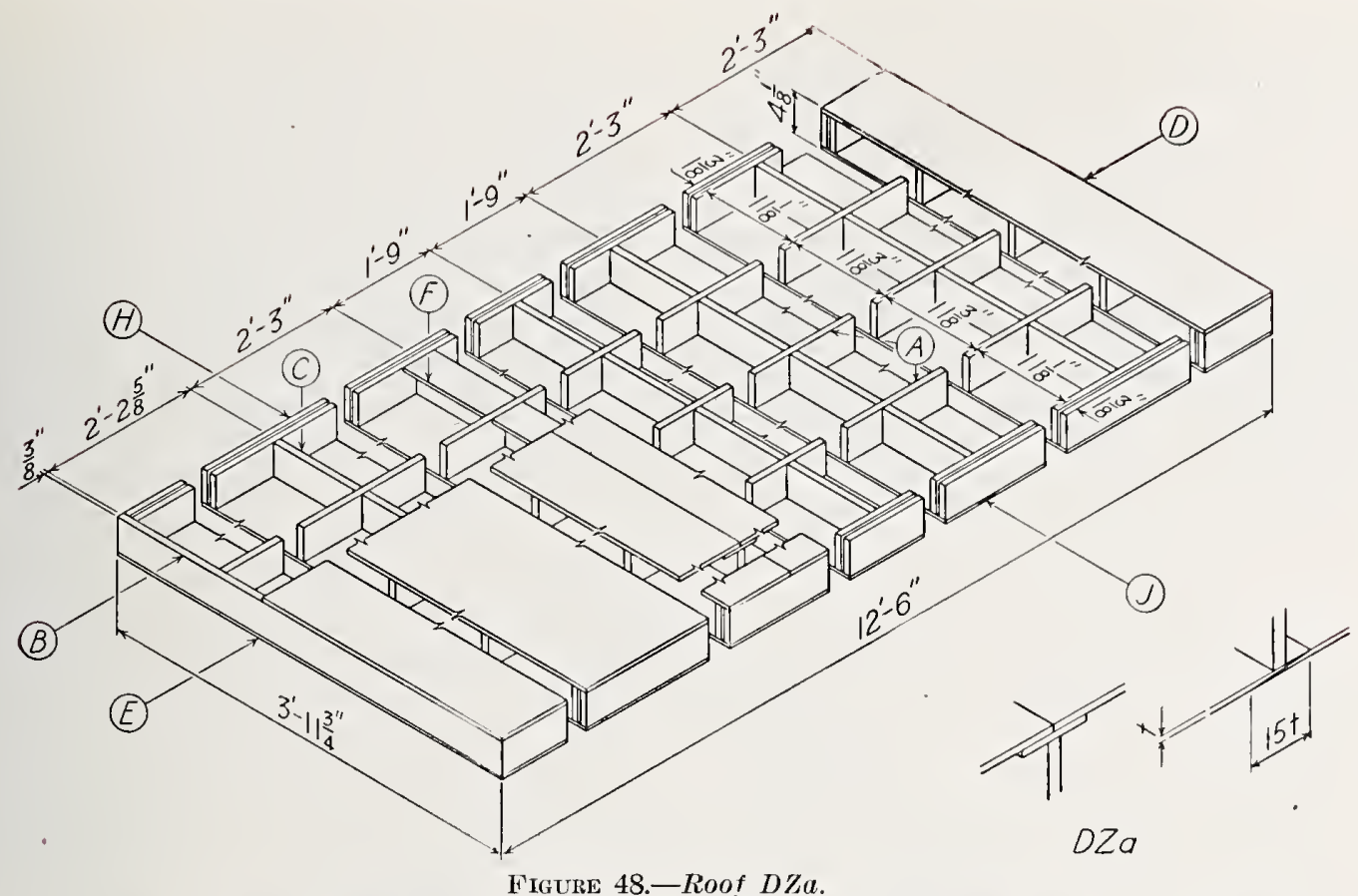

$A$, joist ; $B$, header ; $C$, bridging; $D$, sheathing; $E$, ceiling; $F$, sheathing splice strip ; $I$, half splines.

if there had been scarf joints in the inside face of the roof, the transverse strength would have been greater. The sponsor furnished the $D Z a$ specimens having scarf joints to enable the difference in strength to be determined.

\section{Transverse Load}

The results of the transverse load on roof specimens $D Z a-T 1, T \%$, and $T S$ are given in table 10 and in figure 49 .

The speed of the movable head of the testing machine was adjusted to $0.032 \mathrm{in}$. $/ \mathrm{min}$.

Loud noises, probably caused by the failure of the glue joints, were first heard at a load of $1+6,92$, and $169 \mathrm{lb} / \mathrm{ft}^{2}$ for specimens $T 1 a$, T2 $a$, and T3a, respectively. Upon release of load of $180 \mathrm{lb} / \mathrm{ft}^{2}$, the scarf joint failed and the bottom plywood near the joint buckled in specimen Tla. The bottom plywood of specimen T'a failed in tension at the third point at a load of $217 \mathrm{lb} / \mathrm{ft}^{2}$. Under the maximum load, the scarf joint of specimens $T 2 a$ and $T 3 a$ failed. Examination after test disclosed a tensile failure in four joists of T1a. One joist failed in horizontal shear and four joists failed in tension in T\%a. Four joists and one half spline failed in horizontal shear and one joist and the other half spline broke in tension in T3a.

The average transverse strength of the roof specimens $D Z a$, having scarf plywood ceiling

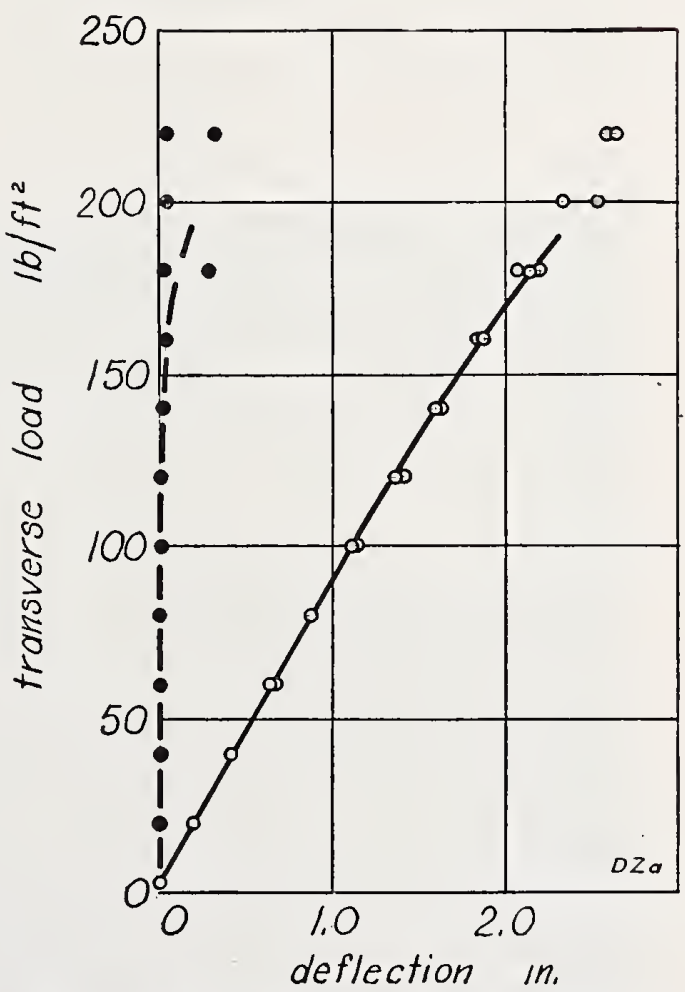

Figure 49.-Transverse load on floor $D Z a$.

Load-deflection (open circles) and load-set (solid circles) results for specimens $D Z a-T 1, T 2$, and $T 3$, on tlie span $12 \mathrm{ft} 0$ in. The load (pounds per square feet) is the total load divided by the product of the span and the
width of the specimen. 
joints, was 34 percent greater than that of the roof specimens $D Z$, which had butt plywood ceiling joints.

\section{ADDITIONAL COMMENTS BY SPONSOR}

It is estimated that over ten thousand houses have been built from prefabricated panels similar to these specimens as produced by six different manufacturers. The location of these louses extends from coast to coast and is usually within a trucking range of 300 miles from factory.
These constructions are designed to be erected on any conventional type of masonry foundation. For pitched roof construction, ceiling panels are similar to floor panels, except that if attic space is not to be used for storage, the flooring face is omitted. Outside walls and roofs or ceilings are usually provided with thermal insulation in the form of a fiber blanket having a vapor-proof paper covering the inside face. A typical section is shown in figure 50 .

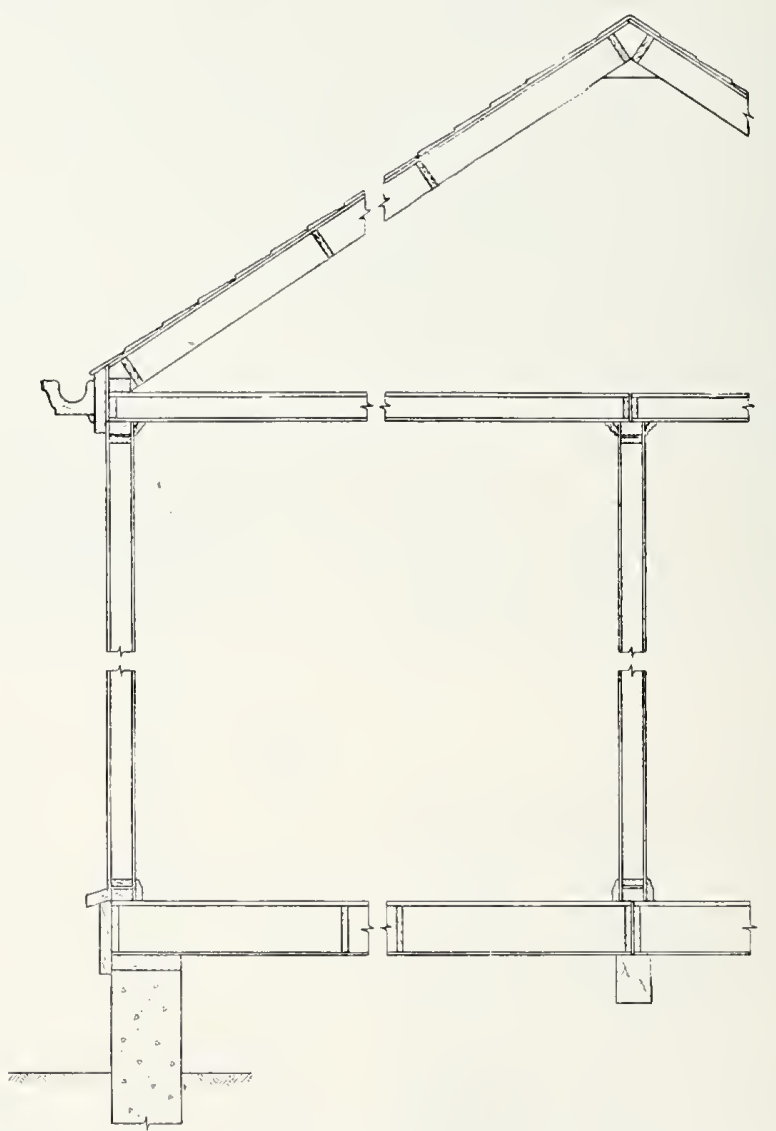

FIGURE 50.-Typical details of a house assembly having lightweight plyucood construction.

\section{PART 2. COMMERCIAL TYPE CONSTRUCTION}

\section{SPONSOR AND PRODUCT}

The specimens were submitted by the Douglas Fir Plywood Association, Tacoma, Wash., and were built by the Pease Woodworking Co., Cincinnati, Ohio, manufacturers of prefabricated houses employing Douglas fir plywood in their products. The constructions consisted of conventional frames with faces of Douglas fir plywood. The outside face was fastened by nails, the inside face by nails and glue. Buildings were designed to be erected on con- ventional masonry foundations, the wall panels joined by plywood splines.

\section{SPECIMENS AND TESTS}

The specimens represented walls, and were assigned the following symbols: 4 -ft and $8-\mathrm{ft}$ specimens with commercial type construction, EA; 8-ft specimens with blocking between studs, EAa; and 8-ft specimens with diagonal braces, $E A b$. The individual specimens were assigned the designations listed in table 11. 
TABL: 11. Specimen designations

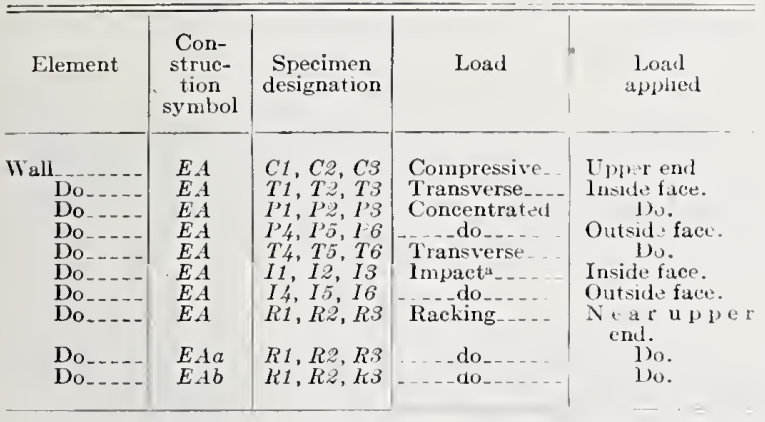

a The concentrated and inpact loads were applied to the same specimen, impact loads first.

Because there was no reason to believe that the continuous girts, blocks, or diagonal braces between the studs affected the compressive. transverse, concentrated, or impact strength ot the wall specimens, the specimens $E A a$ and $E A b$ were subjected only to racking load.

The specimens were tested in accordance with BMS2 with the same exceptions mentioned in Part 1.

\section{MATERIALS}

Information on the materials was obtained from the sponsor and by inspection of the specimens, except that the Forest Products Laboratory assisted by identifying the species of wood, and the Engineering Mechanics sec- tion of the National Burean of Standards assisted by determining the moisture content of the wood.

\section{Toos \\ (a) Framing}

The wood for the framing was Douglas fir, except in compressive specimen, $C \%$, and racking specimens $E A-R 1, R:$, and $R 3$, where the species of wood was hemlock, common No. 1 " better, sts, (surfaced four sides), in the following sizes:

$$
\begin{aligned}
& 25 / 32 \text { by } 21 / 2 \text { in. (nominal } 1 \text { by } 3 \mathrm{in.} \text { ) } \\
& 15 / 3 \text { by } 35 / 5 \text { in. (nominal } 2 \text { by } t \text { in.) }
\end{aligned}
$$

\section{(b) Plywood}

Douglas fir, $1 / 4$ and $5 / 16$ in., bonded with water-resistant protein glue having a soya-bean and casein base. The $1 / 4^{-11}$. plywood was 3-ply, wallboard grade, sanded, and complied with Douglas Fir Plywood Association "Plywall." The $5 / 16$-in. plywood was 3-ply, sheathing grade, and complied with Douglas Fir Plywood Association "Plyseord." All Plywood complied with Commercial Standard CS $45-42$.

After each specimen was tested, the inside face was removed to expose the framing, and samples of framing and plywood were cut for identification of species. Figures 51 to 54 are typical specimens.
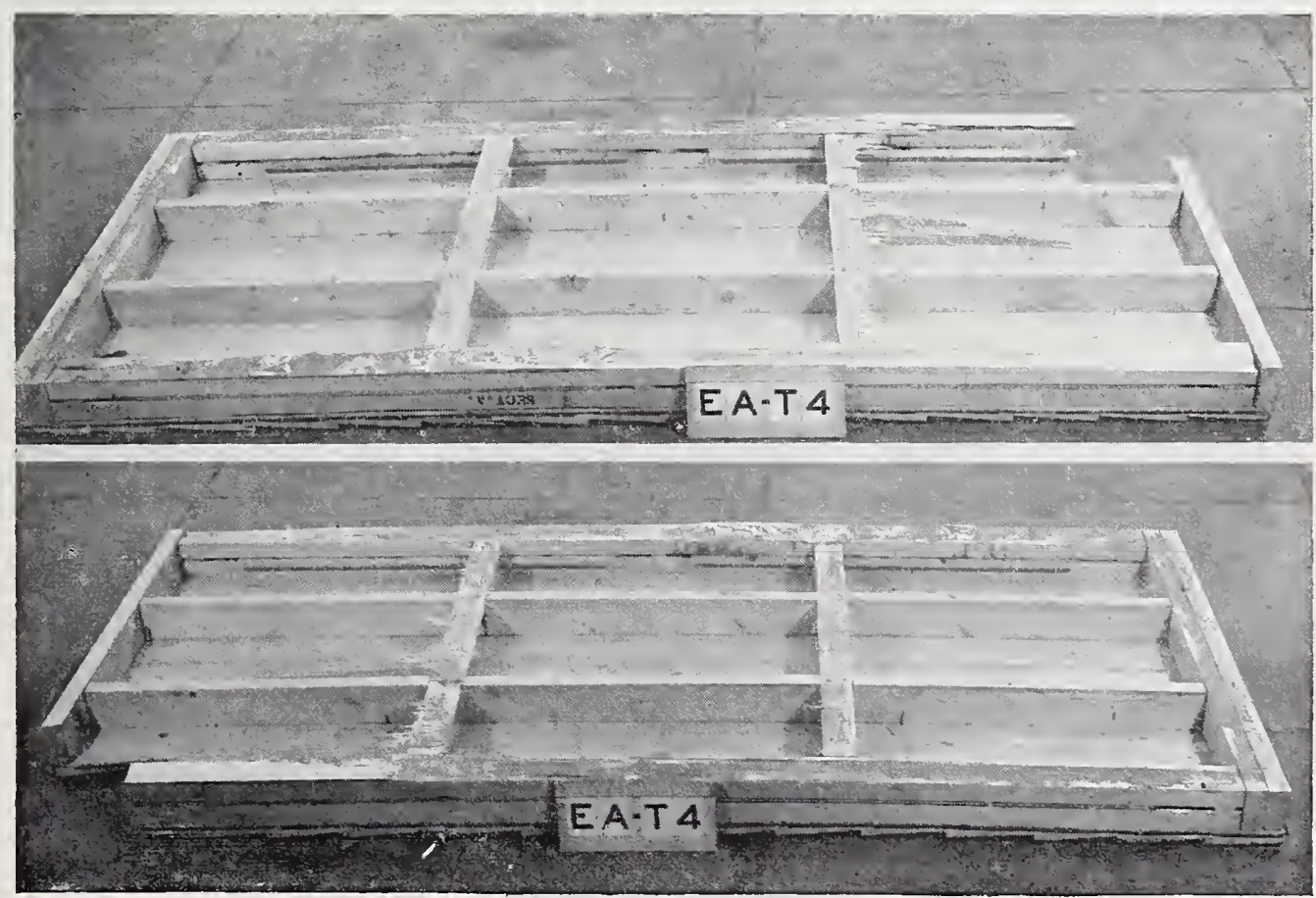

Figure 51.-Wall EA.

Typical 4-foot specimen. 
Samples of plywood and framing were taken from each specimen on the day the specimen was tested; they were weighed and then dried to constant weight in an oven at $212^{\circ} \mathrm{F}$. The moisture content, given in table 12, was calculated on the oven-dry weight.

TABLE 12.-Moisture content of the wood [Determined on the day wall specimen was tested]

\begin{tabular}{|c|c|c|c|}
\hline \multirow[b]{2}{*}{ Wood } & \multicolumn{3}{|c|}{ Moisture content } \\
\hline & Minimum & Maximum & Arerage \\
\hline & Percent & Percent & Percent \\
\hline Framing $\ldots \cdots$ & $\begin{array}{r}10 \\
8\end{array}$ & 13 & 11 \\
\hline $\begin{array}{l}\text { Bevel siding } \text { Douglas fir plywood, }{ }_{1 / 4} \text {-in. }\end{array}$ & $\begin{array}{l}8 \\
7\end{array}$ & $\begin{array}{l}10 \\
10\end{array}$ & $\begin{array}{l}9 \\
9\end{array}$ \\
\hline Douglas fir plywood, $5 / 6^{-11}$. & 7 & 10 & 8 \\
\hline
\end{tabular}

(c) Furring

Furring was wood lath, $3 / 8$ by $1 \frac{1}{2}$ in., in 4 -ft 0 -in. lengths, true fir, rough.

\section{(d) Bevel Siding}

Bevel siding was hemlock, except for compressive specimen, $C O$, and racking specimen,
EA $a-R 1$, where the species of wood was true fir, select, grade $\mathrm{C}$ or better, $7 / 16$ by $3 / 16$ by $71 / 4$ in.

\section{Sheathing Paper}

Sheathing paper was "Slaters Felt," bituminous-saturated felt-paper base, weight $25 \mathrm{lb} /$ $500 \mathrm{ft}^{2}$, width 30 -in.

\section{NAiLS}

All the nails were steel wire nails and are described in table 13.

TABLE 13.-Description of nails

\begin{tabular}{|c|c|c|c|c|c|c|}
\hline Type & Size & Length & $\begin{array}{l}\text { Stcel } \\
\text { wire } \\
\text { gage }\end{array}$ & $\begin{array}{c}\text { Di- } \\
\text { ameter }\end{array}$ & Finish & $\begin{array}{c}\text { Nails } \\
\text { per } \\
\text { pound }\end{array}$ \\
\hline $\begin{array}{c}\text { Box } \\
\text { Do } \\
\text { Do- } \\
\text { Do- }\end{array}$ & $\begin{array}{r}\text { Penny } \\
5 \\
6 \\
8\end{array}$ & $\begin{array}{c}\text { in. } \\
13 / 4 \\
2 \\
23 / 8\end{array}$ & $\begin{array}{l}\text { No. } \\
14 \\
121 / 2 \\
121 / 2\end{array}$ & $\begin{array}{c}\text { in. } \\
0.080 \\
.0985 \\
.0985\end{array}$ & $\begin{array}{l}\text { Bright } \\
\text { Cement- }\end{array}$ & $\begin{array}{l}406 \\
236 \\
186\end{array}$ \\
\hline $\begin{array}{l}\text { Common- } \\
\text { Finshing } \\
\text { Lath.-- }\end{array}$ & $\begin{array}{r}12 \\
3 \\
3\end{array}$ & $\begin{array}{l}31 / 4 \\
11 / 4 \\
11 / 4\end{array}$ & $\begin{array}{l}9 \\
151 / 2 \\
14\end{array}$ & $\begin{array}{l}.1483 \\
.0673 \\
.080\end{array}$ & $\begin{array}{r}\text { Codight } \\
\text { Bright } \\
- \text { do do._. }\end{array}$ & $\begin{array}{r}63 \\
807 \\
568\end{array}$ \\
\hline
\end{tabular}

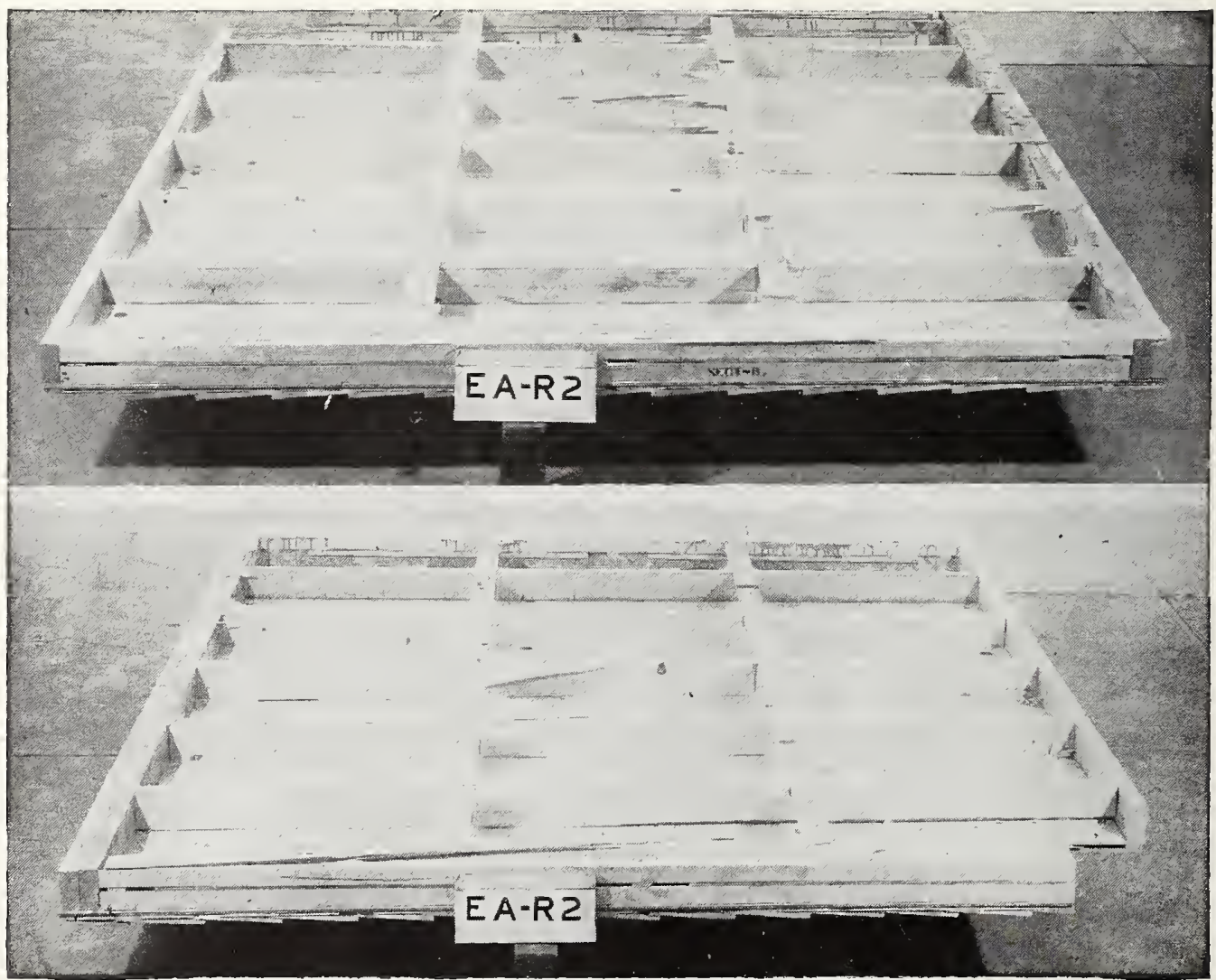

Figure 52.-Wall EA.

Typical 8-foot specimen. 


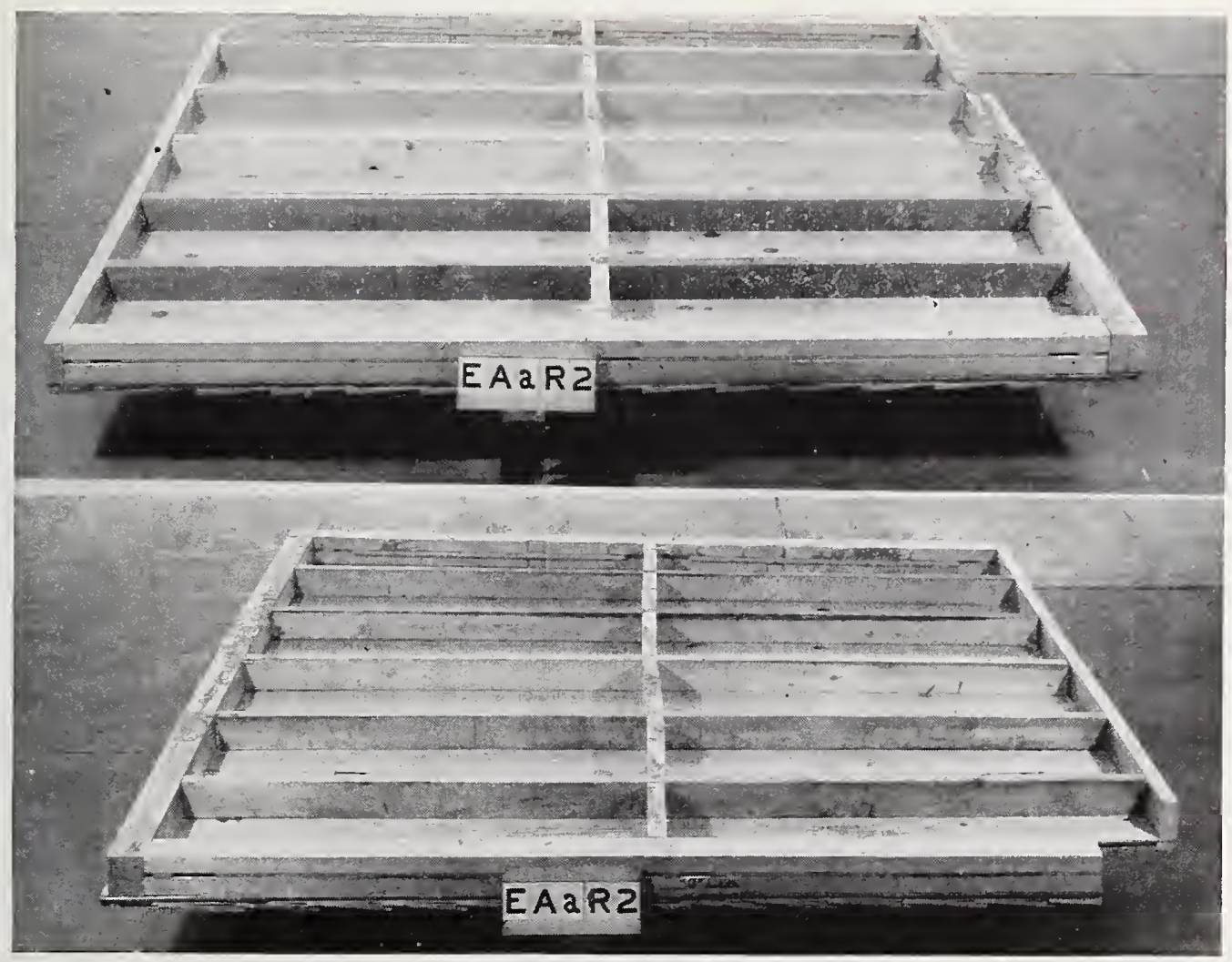

Figure 53.-Wall EAa.

Typical 8-foot specimen.
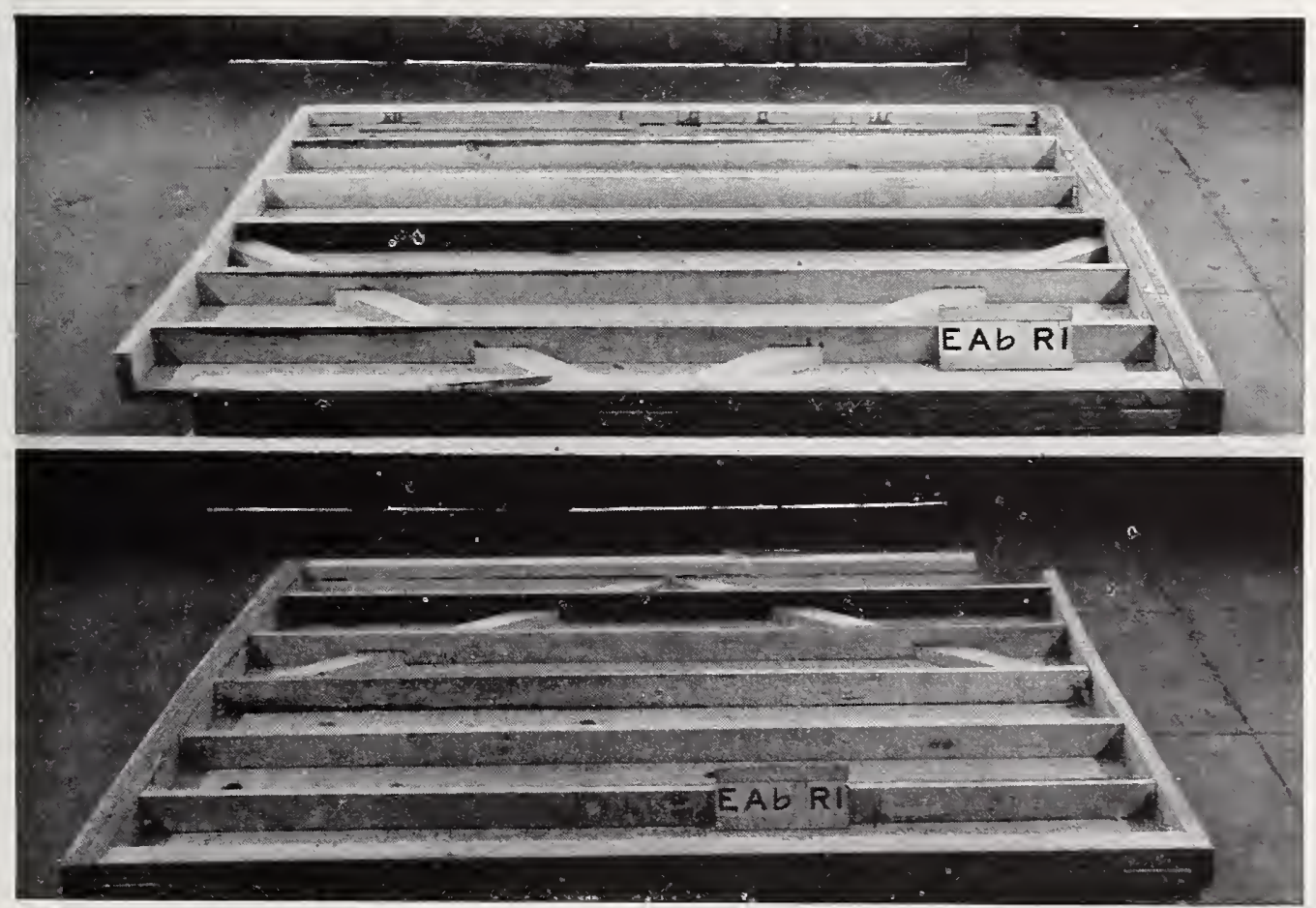

Figure 54.-Wall EAb.

Trpical s-foot specímen. 


\section{Staples}

Tacker staples, formed of sheet steel, No. 25 U. S. Standard Gage (0.0214 in. thick), $0.05 \mathrm{in}$. wide; staple $7 / 16$ in. wide, $5 / 16$ in. long, coated with copper film.

Tacker staples, formed of sheet steel, No. 26 U. S. Standard Gage (0.0187 in. thick), 0.05 in. wide; staple $T / 16$ in. wide, $1 / 2$ in. long, coated with copper film.

\section{Glue}

Casein glue, grade $A$, ground. Formula: Casein, 65 percent; lime, 15 percent; and dispersing agents and undisclosed ingredients, 20 percent. I. P. Laucks, Inc., "Lauxein 888."

\section{Pinnt}

The formula for the interior primer is giren in table 14.

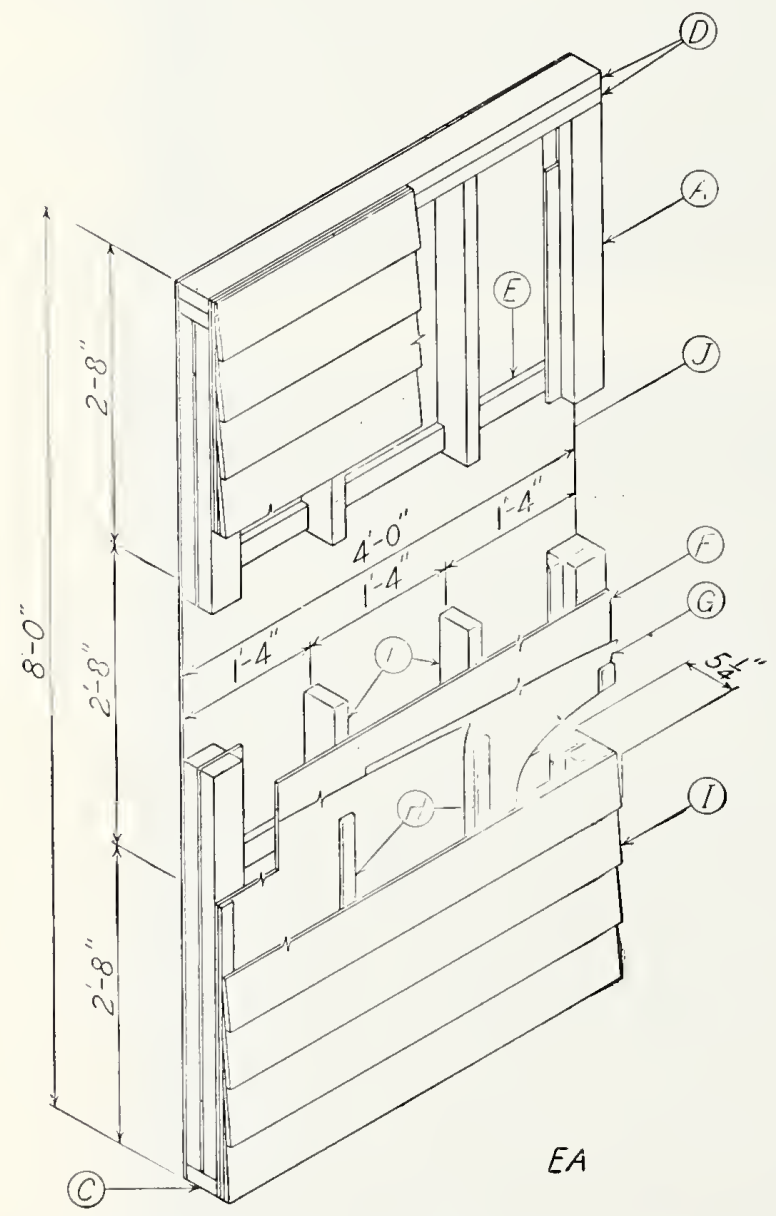

Tigune 55.-Four-foot wall speeimen EA.

1. 1'refabricated outer stud; $B$, inner stud; $C$, floor plate; $D$, top plate ; $E$, girt; $F$, plywood sheathing; $G$, sheathing paper; $I I$, furring; $I$, bevel siding; $J$, inside face.
TABLE 14.-Formula for interior primer [Pigment 59 percent, vehicle 41 pereent, by weight]

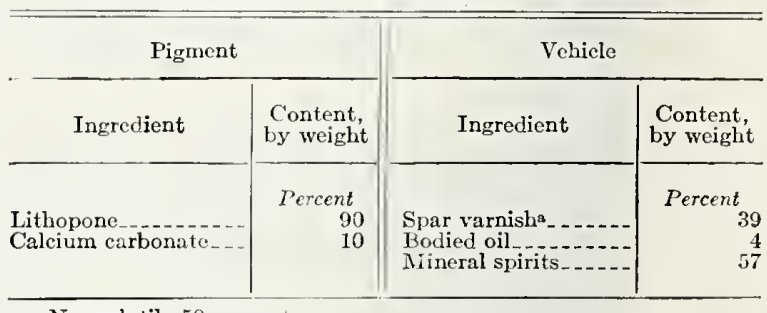

a Nonvolatile 50 precoat.

\section{WALL EA}

1. Sroxsor's Statement

Wall E.1 was a conventional wood frame with plywood on both faces. The outside face was covered with berel siding over furring strips, so that enclosed air spaces were formed, providing thermal insulation. The outside face was fastened with nails, and the inside face with nails and glue. The inside face was coated with a paint primer to provide a rapor barrier.

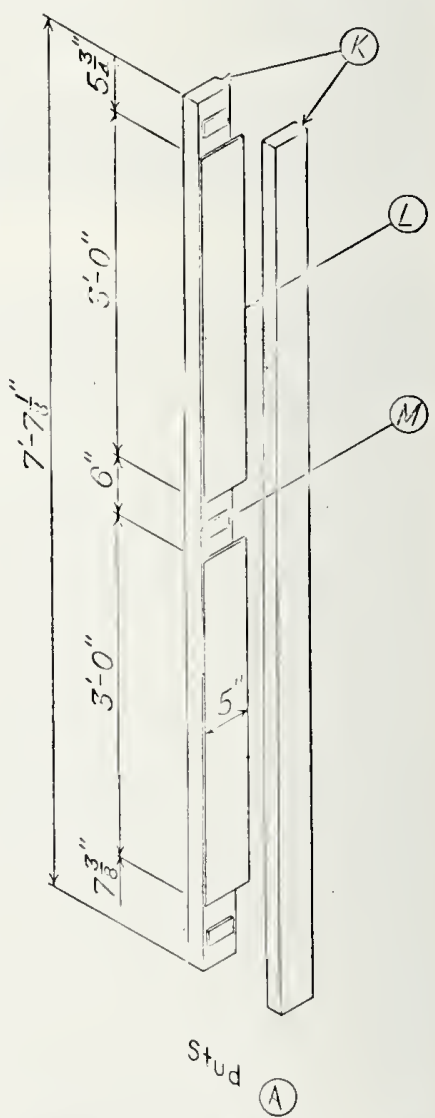

FIGURE 56,-Dctails of outer stud of wall specimen $E A$.

$A$, Stud; $K$, dimension lumber ; $L$, spline; $\mathbb{I I}$, block. 
The price of this construction in Washingtoll, D. C. as of July 1937 was $\$ 0.26 / \mathrm{ft}^{2}$.

\section{(a) Four-Foot Wall Specimens}

The 4-ft wall specimens shown in figure 55 were $8 \mathrm{ft} 0 \mathrm{in}$. high, $4 \mathrm{ft} 0 \mathrm{in}$. wide, and $5^{1 / 4} \mathrm{in}$. thick. Each was a wood frame to which the faces were fastened. The frame consisted of four studs; two prefabricated outer studs, $A$, and two inner studs, $B$, fastened to a floor plate, $C$, and a top plate, $D$, by nails. There were two lines of continuous girts, $E$, extending between the outer studs along the inside face, and let into the inner studs. The outside face consisted of one piece of plywood sheathing, $F$, sheathing paper, $G$, furring, $I I$, and bevel siding, $I$. The inside face, $J$, was one piece of plywood, coated with paint.

Studs.-The outer studs, $A$, shown in figure 56 , were prefabricated nembers placed at the sides of the specimens, each consisting of two pieces of dimension lumber, $K, 15 \%$ by $35 / 8 \mathrm{in}$. (nominal 2 by 4 in.) $7 \mathrm{ft} 71 / 8$ in. long, two plywood splines, $L$, and three plywood strips, $M$.

Plywood splines, $L$, were each one piece of Douglas fir plywood, moisture-resistant type, $5 / 16$ in. thick, $3 \mathrm{ft} 0$ in. long, and 5 in. wide, fustened by glue and nails between the two pieces of dimension lumber.

Plywood strips, $M$, were each one piece of Douglas fir plywood, moisture-resistant type, $5 / 16$ in. thick, 3 in. long, and $1 \frac{1}{2}$ in. wide, fastened by glue and nails between the two pieces of dimension limber.

The two pieces of dimension lumber with the splines and strips between were.fastened together by glue and twelve 12 d common nails driven through the pieces of dimension lumber, splines and strips, three nails to each spline and two to each strip.

Each stud was fastened to the floor and top plates by four 12d common nails driven through the plates into the stud ends.

Inner studs, $B$, were dimension lumber, $15 / 8$ by $3 \frac{5}{8}$ in. (nominal 2 by 4 in.) $7 \mathrm{ft} 71 / 8$ in. long, spaced $1 \mathrm{ft} 4 \mathrm{in}$. on centers. Each stud was fastened to the floor and top plates by two $12 \mathrm{~d}$ common nails driven through the plates into the stud ends.

Plates.-The floor plate, $C$, was dimension lumber, $15 \frac{8}{8}$ by $3 \frac{5}{8}$ in. (nominal 2 by 4 in.) $4 \mathrm{ft}$ 0 in. long.

The top plate, $D$, was two pieces of dimension lumber, $15 / 8$ by $35 / 8$ in. (nominal 2 by 4 in.) $4 \mathrm{ft} 0 \mathrm{in}$. long, fastened by $12 \mathrm{~d}$ common nails driven through the plates into the stud ends. There were two nails driven into the inner studs. The number of nails in the outer studs varied from two to four.
Girts.-The two girts, $E$, were wood strips, $25 / 32$ by $21 / 2$ in. (nominal 1 by $3 \mathrm{in}$.) $3 \mathrm{ft} 41 / 4 \mathrm{in}$. and $t \mathrm{ft} 0 \mathrm{in}$. long, spaced $2 \mathrm{ft} 8 \mathrm{in}$. on centers, fastened to each of the inner studs by two $8 d$ box nails driven through the girts into the studs, and fastened to each of the outer studs by three $5 \mathrm{~d}$ box nails toenailed into the studs, except in the case of specimens $E . t-I 1,1.3$, and I6, where the girts extended to the outside edges of the specimens and were let into the outer studs and fastened to each by two $8 d$ box nails driven through the girts into the studs.

Sheathing.-The sheathing, $F$, was one piece of Douglas fir plywood, moisture-resistant type, $5 / 16$ in. thick, $8 \mathrm{ft} 0 \mathrm{in}$. long, and $4 \mathrm{ft} 0 \mathrm{in}$. wide, fastened by $8 d$ box nails to the framing members. The nails were spaced approximately $41 / 2$ in. apart along the plates, 6 in. along the outer studs, and $91 / 2$ in. along the inner studs.

Sheathing paper.-Sheathing paper, $G$, was laid longitudinally over the sheathing, and consisted of two sheets $30 \mathrm{in}$. wide, lapped $12 \mathrm{in}$. The paper was fastened by a few scattered tacker staples near the corners of the sheets.

Furring.-Furring, $I$, was strips of wood lath, $3 / 8$ by $11 / 2$ in., laid along the plates and studs, fastened by $3 d$ lath nails, spaced $12 \mathrm{in}$. apart.

Bevel siding.-The bevel siding, $I$, was 15 pieces of wood siding, $7 / 16$ by $3 / 16$ by $71 / 4$ in., $4 \mathrm{ft} 0 \mathrm{in}$. long, laid $63 \% 8$ in. to the weather, except in the case of one specimen, where there were three courses with vertical joints, the joints centered orer inner studs. The siding was fastened by $8 d$ box nails driven through the overlapping edges, one nail at each stud, except at vertical joints, where there was a nail at each side of the joint.

Inside face.-The inside face, $J$, was one piece of Douglas fir plywood, moisture-resistant type, $1 / 4$ in. thick, $8 \mathrm{ft} 0 \mathrm{in}$. long, and $4 \mathrm{ft}$ 0 in. widle, fastened by glue and 3d finishing nails to the framing members. The glue mixture was applied to the outer studs, top plate, and girts. The nails were spaced $41 / 2$ in. apart along the plates and girts and 6 in. along the studs.

\section{(b) Eight-Foot Wall specimens}

The 8-ft wall specimens, shown in figure 57 , were $8 \mathrm{ft} 0 \mathrm{in}$. high, $7 \mathrm{ft} 113 / 4$ in. wide, and $51 / 4$ in. thick. The specimens were similar to the 4-ft specimens except for the following: There were five inner studs; the plates were $7 \mathrm{ft} 113 / 4$ in. long; the girts $7 \mathrm{ft} 41 / 2$ in. long; the sheathing was two pieces $3 \mathrm{ft} 11 \% / 8$ in. wide with a vertical joint over the center stud; the sheathing paper was four sheets, lapped 8 in.; bevel siding was $7 \mathrm{ft} 11^{3} / 4$ in. long, the inside face 
three pieces, the middle piece $4 \mathrm{ft} 0$ in. wide, the outer pieces $1 \mathrm{ft} 117 / 8 \mathrm{in}$. wide; vertical joints were butted joints lapped by splice strips, $N$.

Splice strips.-Splice strips, $N$, were Douglas fir plywood, moisture-resistant type, 1/4 in. thick, $21 / 4$ in. wide, back of vertical joints in inside face between girts and between girts and plates. Strips were fastened by glue and tacker staples. Staples were spaced irregularly, approximately twenty along each joint.

\section{Laboratory Statement}

In previously published Building Materials and Structures Reports on the structural prop- erties of wall construction, the 4 - $\mathrm{ft}$ and the 8 - $\mathrm{ft}$ specimens have been of identical construction except as to specimen width. For these $E A$ walls, however, the 8-ft specimens do not have the prefabricated outer studs spaced $4 \mathrm{ft}$ apart to correspond to the 4 - $\mathrm{ft}$ specimens. It is, therefore, probable that the compressive and transverse strengths of walls built in 8 -ft or longer widths will be smaller than the reported strengths of the 4 -ft wall specimens $E A$.

\section{Compressive Load}

The results of compressive load on wall specimens $E A-C 1, C 2$, and $C 3$, are shown in table 15 and figures 58 and 59.

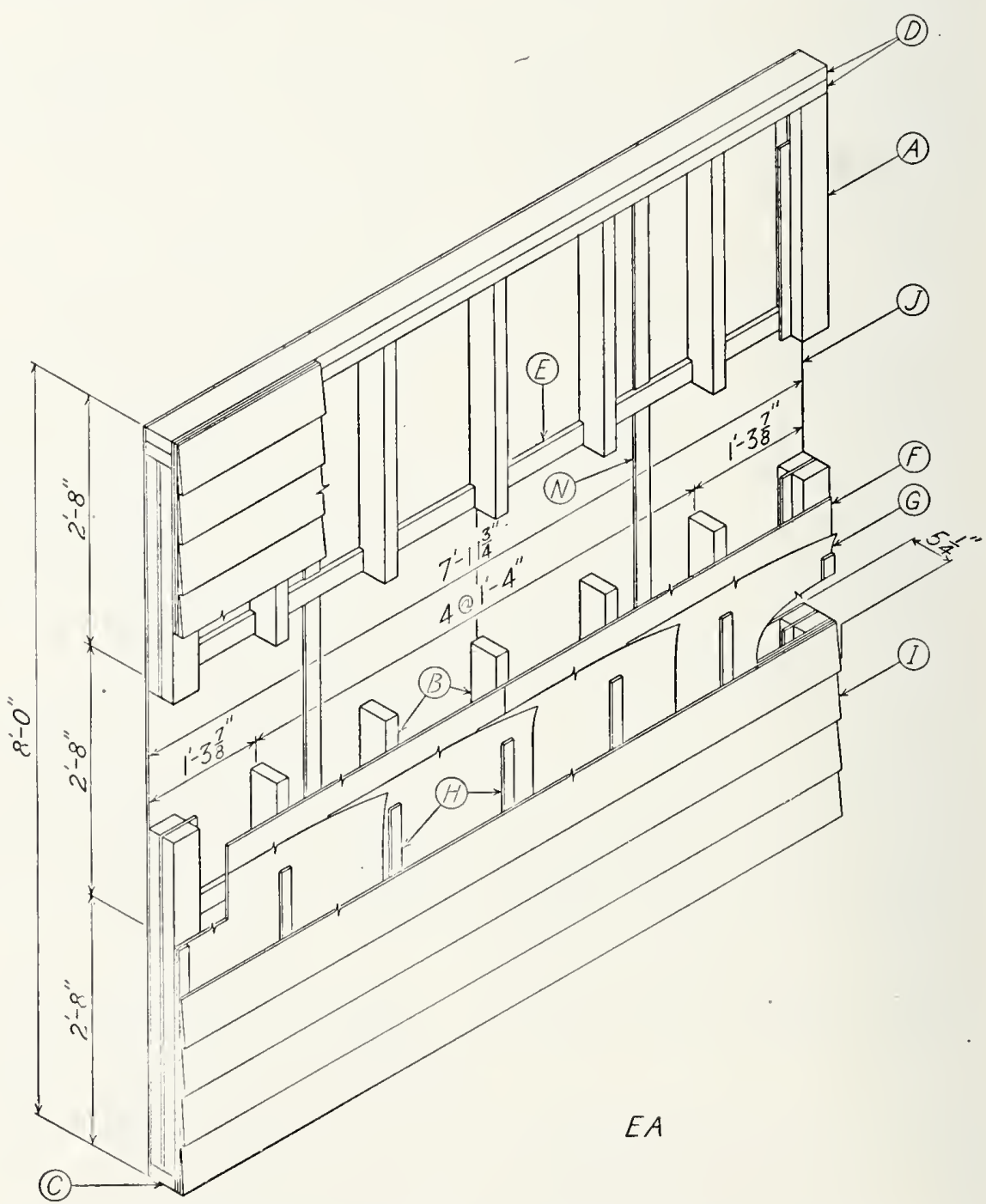

Figure 57.-Eight-foot wall specimen EA.

$A$, Prefabricated outer stud; $B$, inner stud; $C$, floor plate; $D$, top plate; $E$, girt; $F$, plywood sheathing; $G$, sheathing paper; $I I$, furring; $I$, bevel siding; $J$, inside face ; $N$, splice strip. 
TABLE 15. - Structural properties of walls EA, EAa, and EAb

[Weight, based on face area: $E A, 5.23 \mathrm{lb} / \mathrm{ft}^{2} ; E .4 a, 4.9+\mathrm{lb} / \mathrm{ft}^{2} ; E A b, 5.04 \mathrm{lb} / \mathrm{ft}^{2}$ ]

\begin{tabular}{|c|c|c|c|c|c|c|c|c|c|c|}
\hline \multirow{2}{*}{ Construction symbol } & \multicolumn{2}{|c|}{ Compressive load: } & \multicolumn{2}{|c|}{$\begin{array}{l}\text { Transverse load; } \\
\text { span, } 7 \mathrm{ft} 6 \text { in. }\end{array}$} & \multicolumn{2}{|c|}{$\begin{array}{l}\text { Concentrated load; } \\
\text { disk, dianl } 1 \text { in. }\end{array}$} & \multicolumn{2}{|c|}{$\begin{array}{c}\text { Impact load; span, } \\
7 \mathrm{ft} 6 \text { in.: sandbag, } \\
60 \mathrm{lb}\end{array}$} & \multicolumn{2}{|c|}{ Racking load } \\
\hline & Specimen & $\begin{array}{l}\text { Maximum } \\
\text { load }\end{array}$ & Specimen & $\underset{\text { load }}{\text { Maximum }}$ & Specimen & $\underset{\text { load }}{\text { Maximum }}$ & Specimen & $\underset{\text { load }}{\text { Maximum }}$ & Specimen & $\underset{\text { load }}{\text { Maximum }}$ \\
\hline$E A \ldots \ldots$ & $\begin{array}{l}C 1 \\
C 2 \\
C 3\end{array}$ & $\begin{array}{r}K i p s / f t^{\mathrm{b}} \\
9.50 \\
7.87 \\
9.00\end{array}$ & $\begin{array}{l}T 1 \\
T 2 \\
T S\end{array}$ & $\begin{array}{r}l b / f t^{2} \\
300 \\
361 \\
393 \\
\end{array}$ & $\begin{array}{l}P 1 \\
P 2 \\
P S\end{array}$ & $\begin{array}{c}l b \\
600 \\
489 \\
470\end{array}$ & $\begin{array}{l}I 1 \\
I 2 \\
I 3\end{array}$ & $\begin{array}{l}f t \\
\mathrm{c} 10.0 \\
\text { c10.0 } \\
\text { d } 10.0\end{array}$ & $\begin{array}{l}R 1 \\
R 2 \\
R S\end{array}$ & $\begin{aligned} K i p 8 / f t^{\mathrm{b}} \\
2.54 \\
2.52 \\
2.14\end{aligned}$ \\
\hline Average .. & - & 8.79 & $-\ldots \ldots$ & 351 & 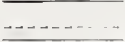 & 520 & $-\ldots$ & 10.0 & $\ldots$ & $\mathrm{e} 2.40$ \\
\hline$E A_{-}$ & & & $\begin{array}{l}T 4 \\
T 5 \\
T 6\end{array}$ & $\begin{array}{l}294 \\
217 \\
326\end{array}$ & $\begin{array}{l}P 4 \\
P 5 \\
P 6\end{array}$ & $\begin{array}{l}766 \\
489 \\
595 \\
\end{array}$ & $\begin{array}{l}14 \\
I 5 \\
J 6\end{array}$ & $\begin{array}{l}\mathrm{c} 10.0 \\
\mathrm{c} 10.0 \\
\mathrm{c} 10.0\end{array}$ & & ב- \\
\hline Average.... & 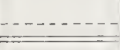 & $\ldots \ldots \ldots$ & $\ldots$ & 279 & (n....... & 617 & 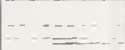 & 10.0 & . & $\ldots$ \\
\hline$E A a_{-}$ & & & & & & & & & $\begin{array}{l}R 1 \\
R 2 \\
R 3\end{array}$ & $\begin{array}{r}1.78 \\
1.77 \\
1.83\end{array}$ \\
\hline A verage & $\ldots \ldots$ & $\ldots$ & 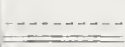 & $\ldots$ & $=$ & 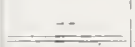 & 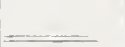 & $\ldots$ & $\ldots$ & $=1.81$ \\
\hline . & & & & & & & & & $\begin{array}{l}R 1 \\
R 2 \\
R 3\end{array}$ & $\begin{array}{l}1.60 \\
1.81 \\
1.82\end{array}$ \\
\hline & & & & & & -. & & & & 01.74 \\
\hline
\end{tabular}

a Load applied 1.37 in. ( $1 / 3$ the effective thickness of the panel) from the inside face.

b A kip is $1,000 \mathrm{lb}$.

c Test discontinued. Specimen damaged.

e Each group of racking specimens, $E A, E A a$, and $E A b$, differed greatly from the other groups in the extent and distribution of the glined surfaces of the inner plywood face.

The compressive loads were applied 1.37 in. (one-third the effective thickness of the panel) from the inside face of the panel.

The shortenings and sets shown in figure 58 for a height of $8 \mathrm{ft}$ were obtained from the compressometer readings. The compressometers were attached to the plates through which the load was applied. The gage length was $8 \mathrm{ft}$. The lateral deflections plotted in figure 59 are deflections toward the outside face of the wall.

The speed of the movable head of the testing machine was adjusted to $0.072 \mathrm{in} . / \mathrm{min}$.

Under the maximum load, the top plate crushed locally at the inside edges of the studs.

Under the maximum load, the inside plywood separated from the studs near the top of specimen $C 1$. The inside face buckled. At a load of $7.0 \mathrm{kips} / \mathrm{ft}$, the inside plywood of $C 2$ buckled and separated from the studs at the top. Under the maximum load, the top plate split. The inside plywood of $C 3$ separated from the top plate at a load of $7.0 \mathrm{kips} / \mathrm{ft}$ and buckled at a load of $8.41 \mathrm{kips} / \mathrm{ft}$. The top plates crushed at a load of $8.0 \mathrm{kips} / \mathrm{ft}$. Examination after test disclosed a horizontal shear failure in one stud of $C \mathscr{Q}$.

\section{Transverse Load}

The results of the transverse-load test are shown in table 15 and in figure 60 for wall specimens $E A-T 1, T 2$, and T\%, loaded on the inside face, and in figure 61 for specimens $E A-T 4, T 5$, and $T 6$, loaded on the outside face.

The speed of the movable head of the testing machine was adjusted to $0.12 \mathrm{in.} / \mathrm{min}$.

The transverse loads were applied to the inside face of specimens $E A-T 1, T 2$, and $T 3$. For specimens $T 1, T 2$, and $T 3$, respectively, the inside face began to buckle between the loading rollers at a load of 160,100 , and $200 \mathrm{lb} / \mathrm{ft}^{2}$, and loud noises, probably caused by the failure of the glue joints, were first heard at a load of 95,140 , and $373 \mathrm{lb} / \mathrm{ft}^{2}$. At a load of $341 \mathrm{lb} / \mathrm{ft}^{2}$, one outer stud failed in tension, and the inside plywood crushed near the tensile failure of the stud in specimen T\%. Under the maximum load, the inside face of $T 1$ separated from the top and bottom plates, and one outer stud of T.3 failed both in tension and horizontal shear. Examination of the specimens after test disclosed tensile failures in three studs and horizontal shear failures in two studs of T1. Four studs broke in tension, two studs failed in com. pression, and two studs had horizontal shear 
failures in specimen $T \%$. Two studs failed in tension, and three studs developed horizontal shear failures in T3.

The transverse loads were applied to the outside face of specimens $E A-T^{T}, T 5$, and $T 6$. For specimens $T 4, T 5$, and $T C$, respectively, loud noises, probably caused by the failure of glue joints, were first heard at a load of 128 , 180 , and $247 \mathrm{lb} / \mathrm{ft}^{2}$ and the inside face began to buckle at a load of 233,200 , and $287 \mathrm{lb} / \mathrm{ft}^{2}$. In specimen $T$, , one outer stud failed in horizontal shear under a loading roller at a load of $283 \mathrm{lb} / \mathrm{ft}^{2}$. In $T 6$, the inside face broke in tension at a load of $271 \mathrm{lb} / \mathrm{ft}^{2}$. Under the maximum load, another onter stud failed in tension in $T$ \% . Examination after test disclosed three studs broken in tension and two studs with horizontal shear failures in specimen $T$ \%. Three studs failed in tension and one stud failed by horizontal shear in $T 5$. Horizontal shear failures were present in four studs, and tensile failures occurred in two studs of $T G$.

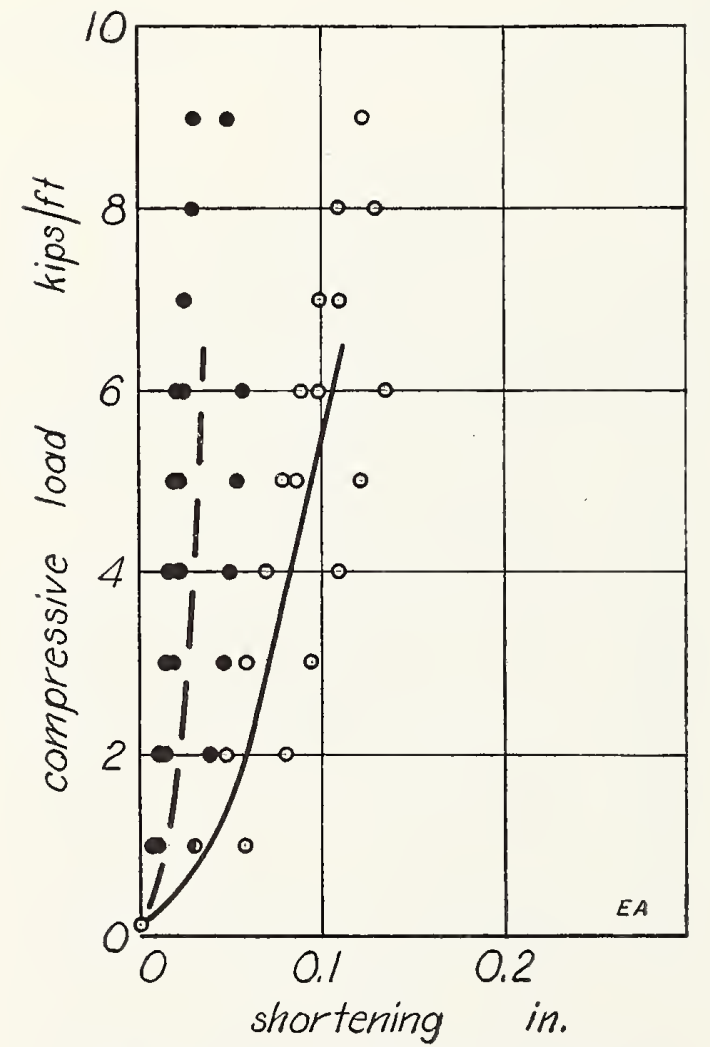

Figure 58.-Compressive load on wall $E A$.

Load-shortening (open circles) and load-set (solid circles) results for specimens $E A-C 1, C 2$, and $C 3$. The load was results for specimens applied 1.37 in. (one-third of the effective thickness of the panel) from the inside face. Th
per foot of actual width of specinen.

\section{Concentrated Load}

Wall specimen $E A-P$ \& under concentrated load is shown in figure 1.

The results of the concentrated-load test are shown in table 15 and in figure 62 for wall specimens $E A-P 1, P Q$, and $P 3$, loaded on the inside face, and in figure 63 for wall specimens $E A-P$.,$P 5$, and $P 6$, loaded on the outside face.

The concentrated load was applied to specimens $E A-P 1, P O$, and $P .3$ midway between two of the studs and $1 \mathrm{ft}+\mathrm{in}$. from one end. Each of the specimens $E A-P 1, P 2$, and $P 3$ failed by the disk punching through the plywood.

The concentrated load was applied to specimens $E A-P /, P 5$, and $P G$ midway between two of the studs and $1 \mathrm{ft}+\mathrm{in}$. from one end. Specimens $E .1-P 4, P 5$, and $P 6$, respectively, developed a transverse crack under the loading disk at a load of 354,281 , and $400 \mathrm{lb}$. Each of the specimens failed by the disk punching through the siding.

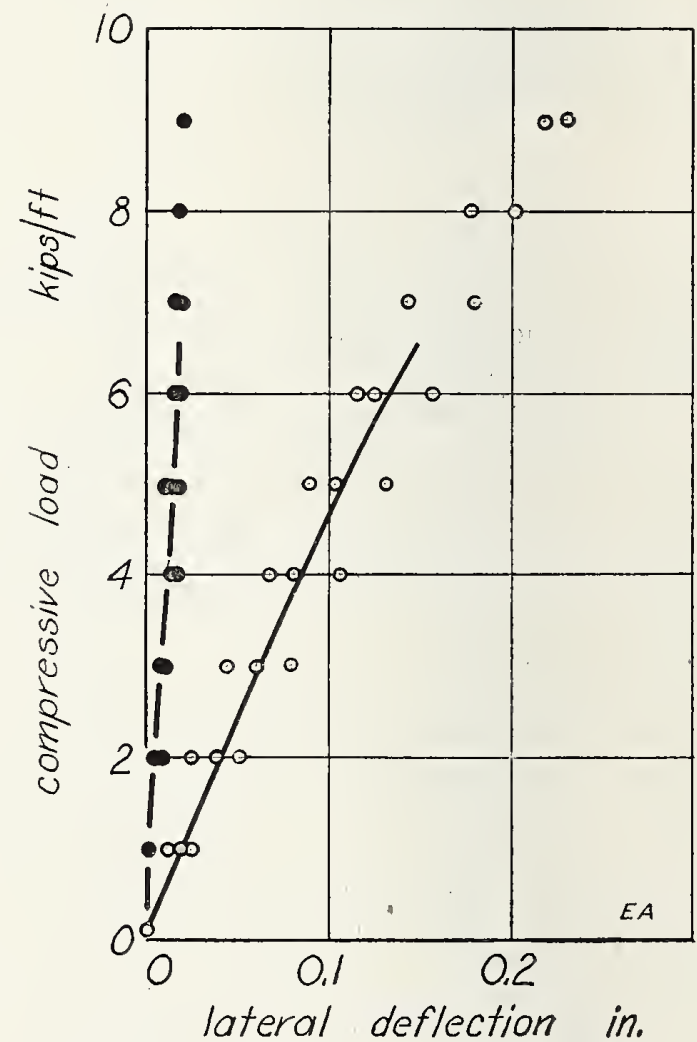

Figure 59.-Compressive load on wall $E A$.

Load-lateral deflection (open circles) and load-lateral sef (solid circles) results for specimens $E A-C 1, C 2$, and $C 3$. The load was applied $1.37 \mathrm{in}$. (one-third of the effective thickness of the panel) from the inside face. The loads are in lips per foot of actual widtl of specimen. Tht: deflections and sets are for a gage length of $7 \mathrm{ft} f$ in. the gage length of the deflectometer. 


\section{IMPACI LOAD}

'The results of the impact-load test are given in table 15 and in figure 64 for specimens $E^{\prime} A-I 1, I 2$, and $I 3$, loaded on the inside face, and in figure 65 for specimens $E A-I 4, I 5$, and 16 , loaded on the outsicle face.

The impact loads were applied to the inside face of specimens $I 1, I \%$, and $I 3$, the sandbag striking the center of the specimen midway between two studs. Ifter a $21 / 2$-ft drop, the plywood of the inside (loaded) face of $I 1$ developed a longitudinal crack from the point of impact of the sandbag to the top of the panel. A longitudinal split in the inside (loaded) face over a stud at midspan developed in specimens $I I$ and $I 2$, respectively, at a height-of-drop of $51 / 2 \mathrm{ft}$ and $61 / 2 \mathrm{ft}$. The deflection was 1.20 and $1.35 \mathrm{in}$. The sandbag broke through the inside face of $I 1$ at a height-ofdrop of $6 \mathrm{ft}$ and broke through the inside face of $I 2$ at a height-of-drop of $7 \mathrm{ft}$. The deflection of $I 1$ was $1.21 \mathrm{in}$. and of $I 2,1.35 \mathrm{in}$. At a height-of-drop of $71 / 2 \mathrm{ft}$, the outside plywood

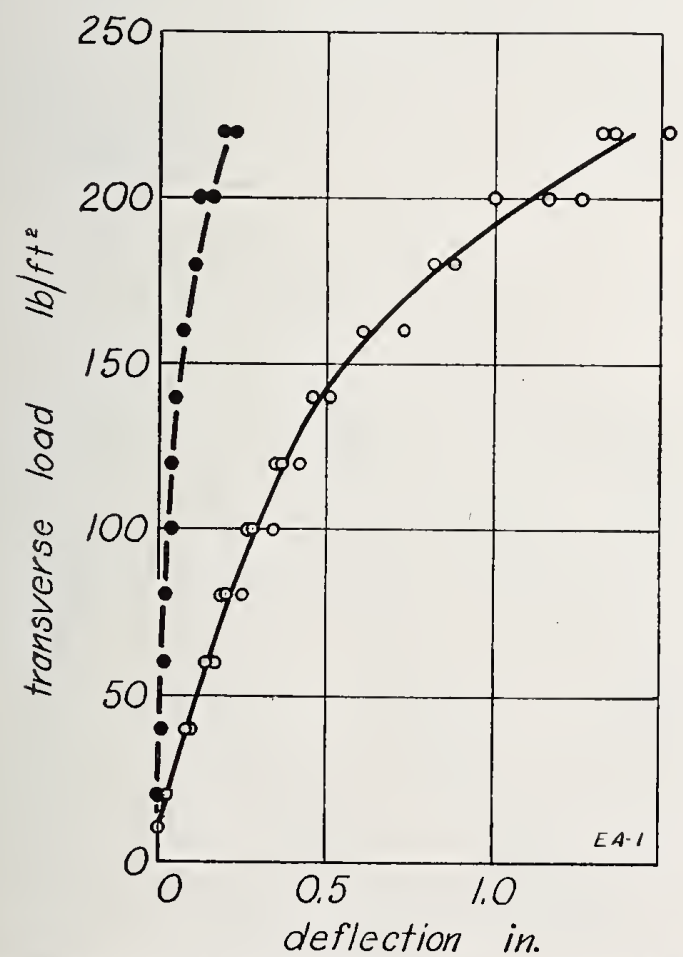

FigURe 60.-Transverse load on wall EA, load applied to inside face.

Load-deflection (open circles) and load-set (solid circles) results for specimens $E A-T_{1}, T_{2}$, and $T_{3}$ on the span 7 results for specimens $E A-T 1$, T2, and $T 3$ on the span 7 $\mathrm{ft} 6$ in. The load (pounds per square foot) is the total
load divided by the product of the span and the width load divided by
of the specimen. separated from the studs of II near the point of impact. The deflection was $2.07 \mathrm{in}$.

After the 10 - $\mathrm{ft}$ drop, the set in 2.3 was 0.076 in. The set readings of $I I$ and $I: 2$ were discontinued after the 6 - $\mathrm{ft}$ drop because the failure of the inside face released the plywood from the studs.

The impact loads were applied to the ontside face of specimens $14, I 5$, and $I 6$, the sandbag striking the siding at the center of the specimen midway between two studs. Ifter a 6 -ft drop, the siding of $I /$ under the sandbag developed a crack. The deflection was $1.59 \mathrm{in}$. The siding of $I_{4}$ adjacent to the sandbag broke under a drop of $9 \mathrm{ft}$. The deflection was $2.05 \mathrm{in}$. In specimen 15 , the siding above the impact area developed a crack at a 4 -ft drop; the siding struck by the bag broke at a 6 -ft drop; and the siding below the impact area (toward the bottom of the wall) failed at a $7-\mathrm{ft}$ drop. The deflections were, respectively, 1.26 in., $1.53 \mathrm{in}$., and $1.70 \mathrm{in}$. In specimen $I 6$, the siding struck by the bag developed a crack at a $21 / 2$-ft drop;

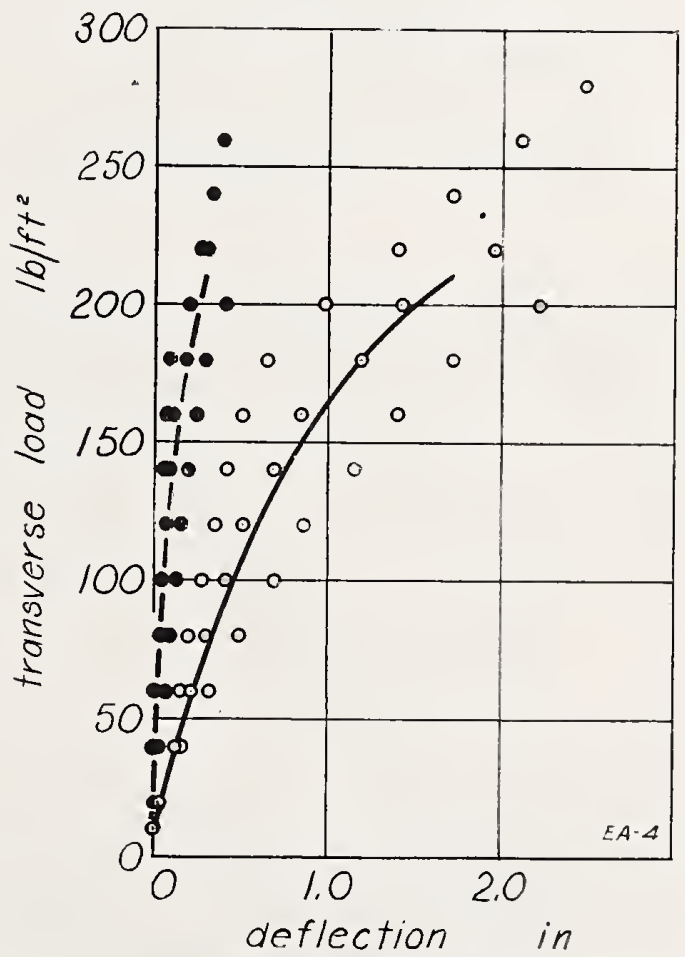

Figure 61.--Transverse load on wall EA, load applied to outside face.

load-deflection (open circles) and load-set (solid circles) results for specimens $E A-T 4, T 5$, and $T 6$ on the span $7 \mathrm{ft} 6$ in. The load (pounds per square foot) is the total load divided by the prodnct of the span and the width of the specimen. 
the siding above the bag broke at a $31 / 2$-ft drop; and after the 10-ft drop, the three pieces of siding at midheight of the specimen were badly broken. The deflection after the $21 / 2$-ft drop

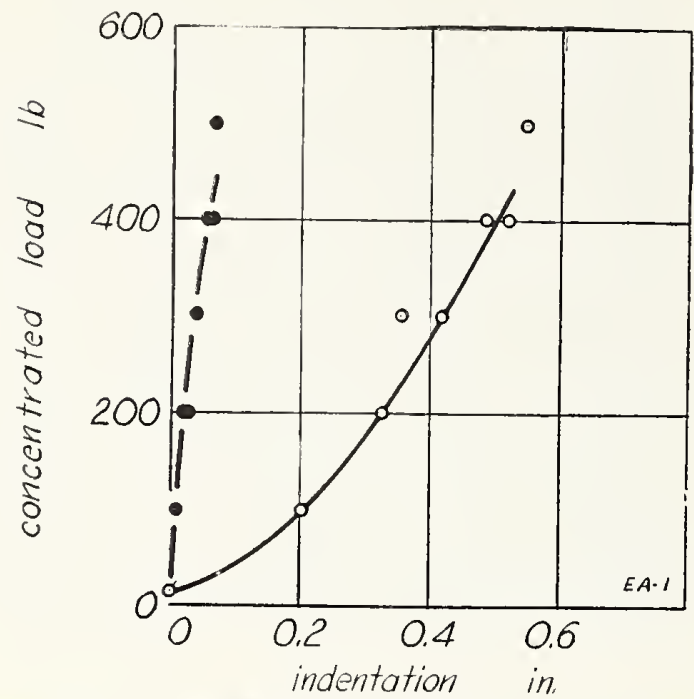

FIguke 62.-Comentrated load on wall $R A$, lond applied to inside face.

Load-indentation (open circles) and load-set (solid circles) results for specimens $E A+P 1, P 2$, and $P$.

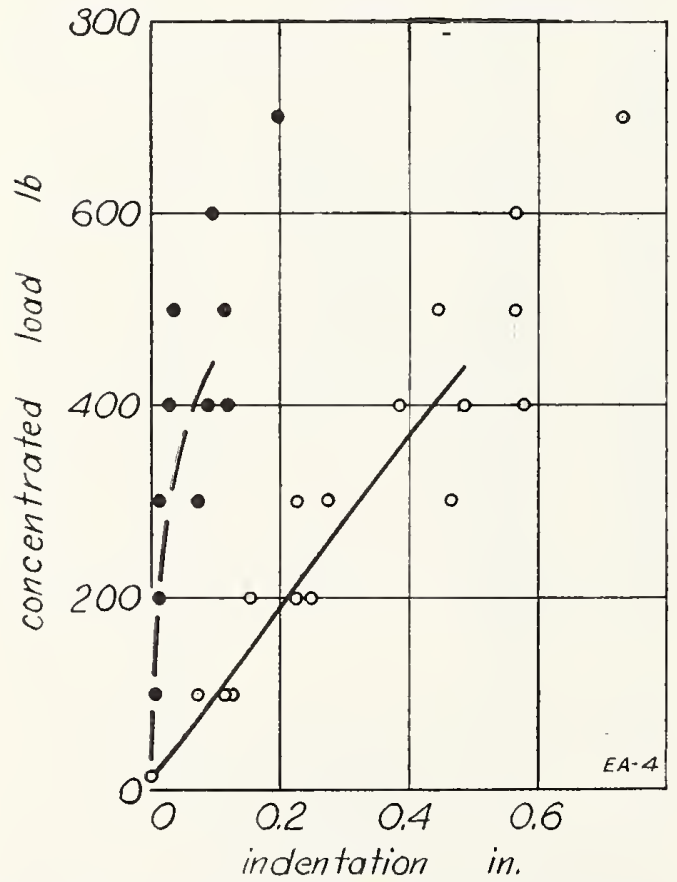

FIgUis: 63.-Concentrated load on wall EA, Load applicd to the outsidc face.

toad-indentation (open circles) and load-set (solid circles) results for specimens $F A-P_{4}, P_{5}$, and $P 6$. was 0.78 in.; after the $31 / 2$-ft drop, $0.98 \mathrm{in.}$; and after the 10 -ft drop, $2.00 \mathrm{in}$.

After the 10-ft drop, the set in 15 was 0.513 in. The set readings of $I / 4$ and $I 6$ were discontinued at height-of-drops of $9 \mathrm{ft}$ and $4 \frac{1}{2} \mathrm{ft}$. respectively, because of failure of the siding.

\section{RaCKing Load}

The results of the racking-load test are given in table 15 and in figure 66 for specimens $E A-$ R1, Ro, and Re.

The racking loads were applied to the top plate, and the stop was in contact with the bottom plate at the diagonally opposite corner of the specimen. The inside plywood broke from the lower plate near the stop at a load of $1.40 \mathrm{kips} / \mathrm{ft}$ for specinten $R \cdot 3$ and of $1.60 \mathrm{kips} / \mathrm{ft}$ for specimens $R 1$ and $R 2$. There was a gradual relative vertical displacement of the edges of the two pieces of plywood on the outside face as the load increased. At the maximum load, the inside plywood was nearly entirely separated from the framing and the angular displacement of the joints between the plates, and the studs became so great that the joints were broken and the specimen failed.

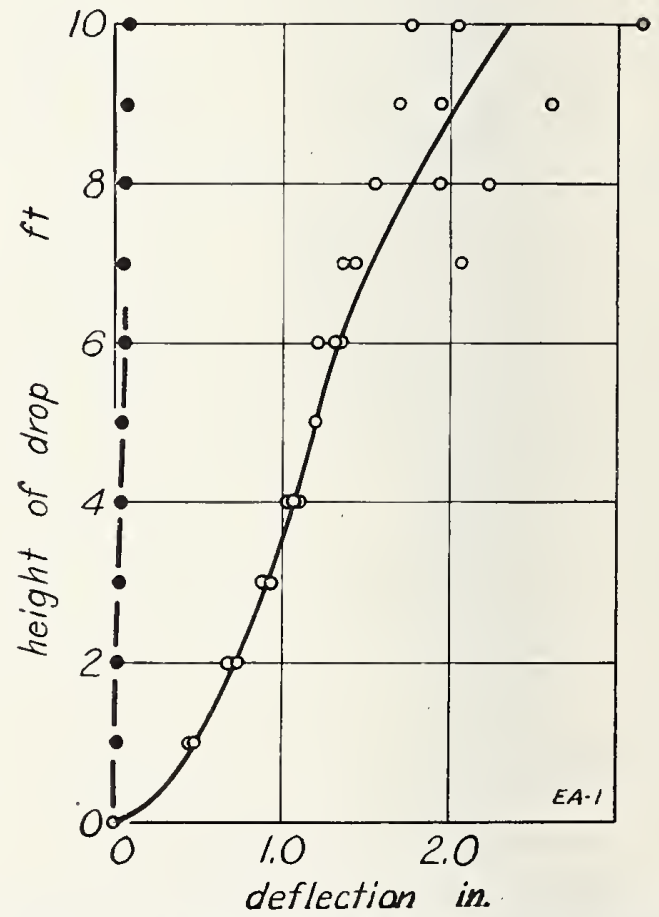

Figle: 64.--Impact load on wall EA, load applied to inside facc.

Height of drop-deflection (open circles) and height of drop set (solid circles) results for specimens $D A-I I, I 2$, and $I S$ on the span 7 it $f$ in. 


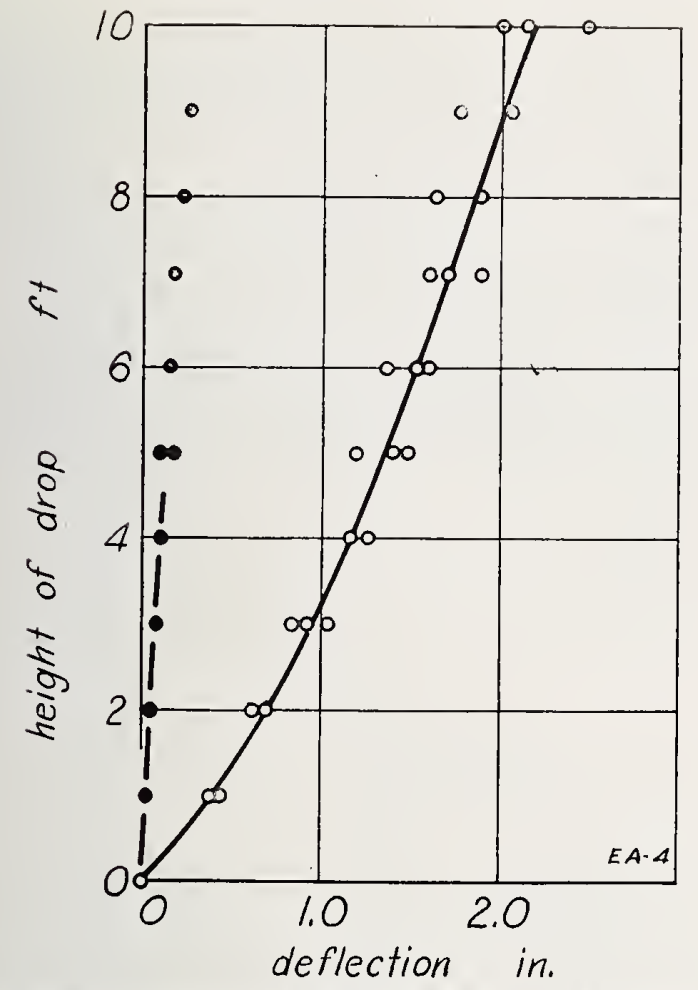

Figure 65.-Impaet load on wall EA, load applied to outside face.

Height of drop-deflection (open circles) and height of dropset (solid circles) results for specimens $E A-I /, 15$, and 16 on the span $7 \mathrm{ft} f \mathrm{in}$.

V. WALL $E A a$

\section{Sponsor's Statement}

\section{(a) Description of Specimens}

The 8 -ft wall specimens, shown in figure 67 , were $8 \mathrm{ft} 0 \mathrm{in}$. high, $7 \mathrm{ft} \mathrm{113/4}$ in. wide, and $51 / 4$ in. thick. The specimens were like the 8 - $\mathrm{ft}$ wall specimens, $E^{\prime} A$, except for the following: girts, $E$, were omitted; one line of blocks, $O$, was extended between the studs at midheight; and glue was applied only to the blocks and to the top plate.

Blocks.-Blocks, $O$, were dimension lumber, $15 \%$ by $35 / 8$ in. (nominal 2 by 4 in.) $1 \mathrm{ft} 23 / 8$ in. long, inserted between the studs in a line at midheight of the specimen. The blocks were fastened to the studs by $12 \mathrm{~d}$ common nails. Two nails were toenailed into the studs alternating with two nails driven through the studs into the ends of the blocks.

\section{RACKING LOAD}

The results of the racking-load tests are given in table 15 and in figure 68 for specimens EAa-R1. R.? and R.3.

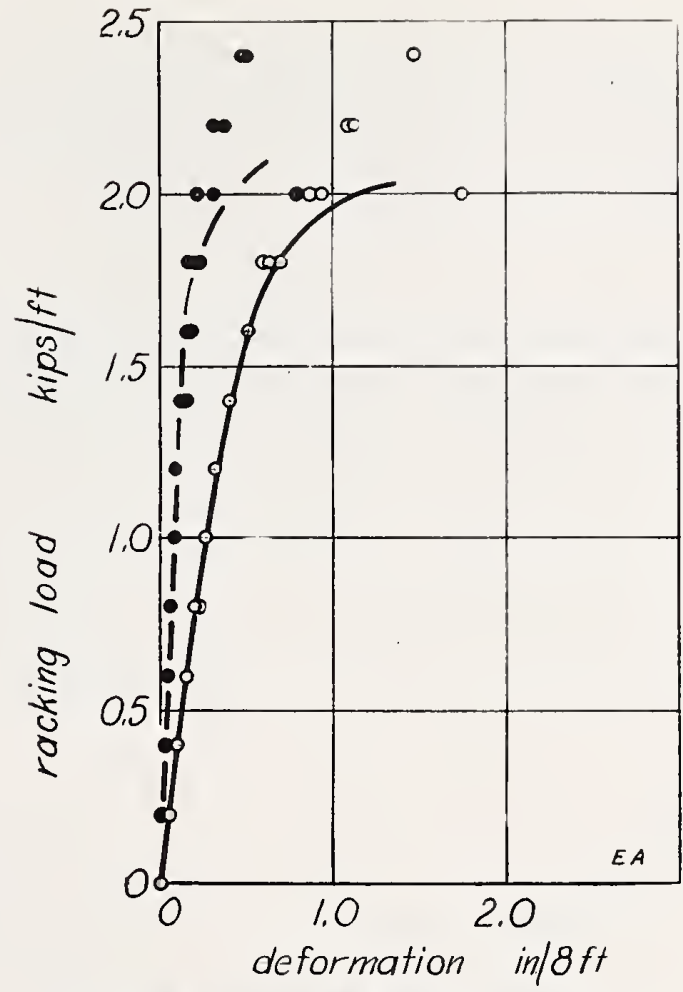

FIGURe 66.-Racking load on wall EA.

Ioad-deformation (open circles) and load-set (solid circles) results for specimens $E A-R 1, R 2$, and $R 3$. The loads are in kips per toot of actual width of specimen.

The racking loads were applied to the top plate, and the stop was in contact with the bottom plate at the diagonally opposite corner of the specimen. 'The inside plywood broke from the lower plate near the stop at a load of $0.80 \mathrm{kips} / \mathrm{ft}$ for specimen $R 1$, and of 1.40 kips/ft for specimens $R 2$ and $R 3$. The final failure was similar to that of the 8 - $\mathrm{ft}$ specimens, $E A$.

VI. WALL EAb

\section{Sponson's Statement}

(a) Description of sperimens

The 8 -ft wall specimens, shown in figure 69 , were $8 \mathrm{ft} 0 \mathrm{in}$. high, $7 \mathrm{ft} 113 / 4$ in. wicle, and $51 / 4$ in. thick. The specimens were like the 8 - $\mathrm{ft}$ wall specimens, $E A$, except for the following: girts, $E$, were omitted; two diagonal braces, $P$, were let into the studs on half the width of the specimen; and glue was applied only to the top plate.

Braces.-Diagonal braces, $P$, were dimension lumber, $15 \%$ by $35 \%$ in. (nominal 2 by 4 in.) 
$5 \mathrm{ft} 7$ in. long, let into the studs and plates at the outside face, and extending from the center of the plates to midheight of one outer stud. The braces were fastened by $12 \mathrm{~d}$ common nails, driven through the braces into the studs and plates, two nails at each bearing.

\section{(b) Comments}

The outside walls of a house consist of panels similar to the specimens, except that the width of panels usually corresponds to the side of a room, and joints are at intersections with partition panels. Wall and partition panels rest on the floor, and are joined together by means of full-size plywood splines, which extend from the outer stud of one panel into the open slot in the outer stud of the adjacent panel. The spline is fastened by nails through the stud.

Sheathing paper, furring, and siding are applied in the field, after the panels are in place. Openings for doors and windows are provided when fabricating the panels. Frames,

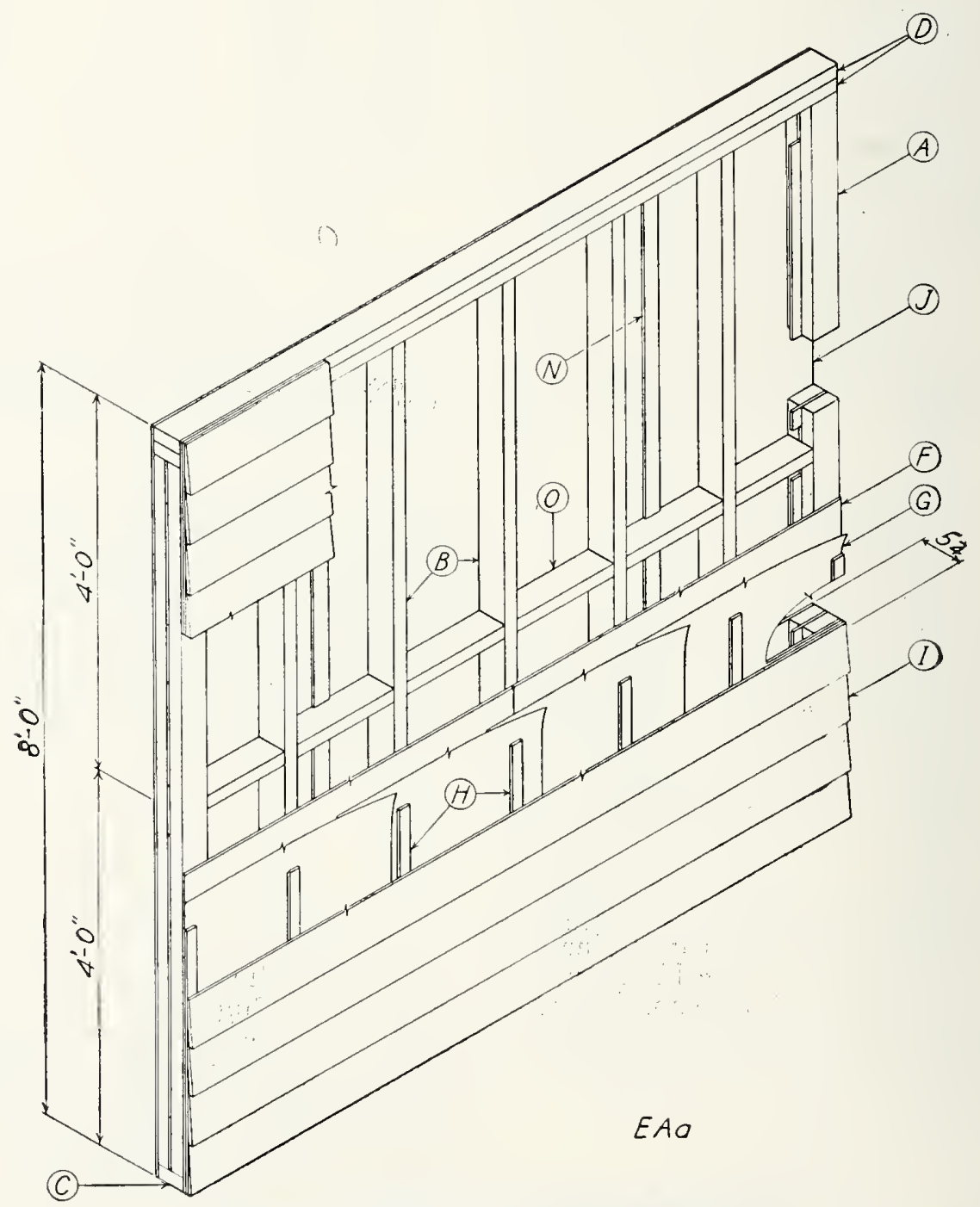

FIGURE 67.-Eight-foot wall specimen EAa.

A, Prefabricated outer stud: $B$, inner stud; $C$, floor plate; $D$, top plate; $F$, plywood sheathing $G$, sheathing paper; $H$, furring; $I$, bevel siding; $J$, inside face; $N$, splice sheathing $G$,
strip; 0 , block. 
sash, and doors are applied in the field. The outside and inside surfaces of this construction are usually finished with paint.

\section{Racking Loid}

The results of the racking-load tests are given in table 15 and in figure 70 for specimens E.Ab-R1,R2, and R3.

The racking loads were applied to the top plate, and the stop was in contact with the bottom plate at the diagonally opposite corner of the specimen. The inside plywood broke from the lower plate near the stop at the load of $1.20 \mathrm{kips} / \mathrm{ft}$ for specimen $R 2$, of $1.40 \mathrm{kips} / \mathrm{ft}$ for specimen $R 1$, and of $1.60 \mathrm{kips} / \mathrm{ft}$ for specimen R3. The final failure was similar to that of the 8-ft specimens, $E A$.

\section{rII. ADDITIONAL, COMMENTS BY SPONSOR}

It is estimated that over five thousand houses have been assembled from prefabricated panels similar to these specimens, as produced by twelve different manufacturers. 'The location of these houses is largely in the middle west.

These constructions are designed to be erected on any conventional type of masonry

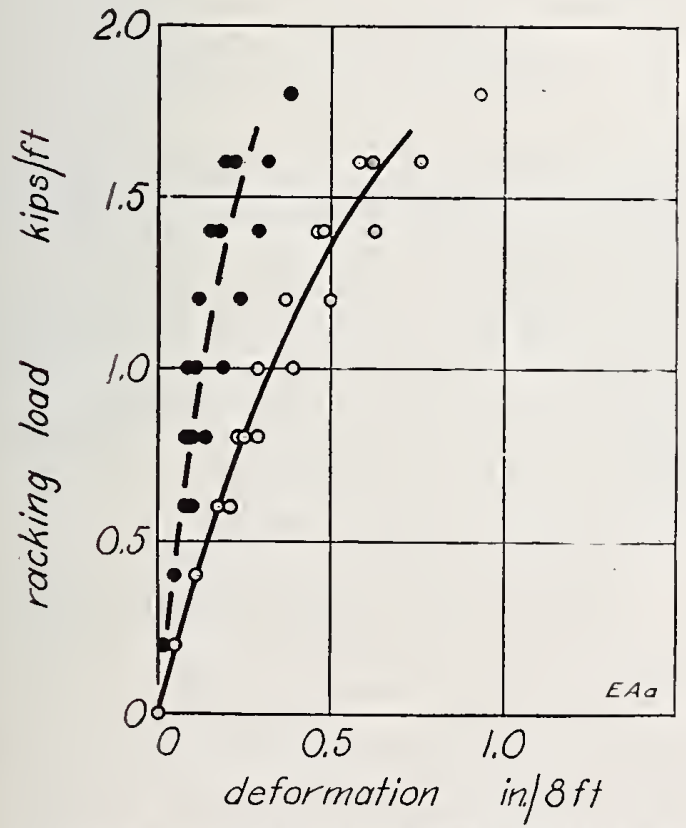

FIGURE 68.-Racking load on wall specimens LAa.

Load-deformation (open circles) and load-set (solid circles) results for specimens $E 4 a-R 1, R 2$, and $R 3$. The loads are in lips per foot of actual width of specimen. foundation. Floors are designed to rest on wood sills or plates, and consist of precut joists and prefabricated floor panels overlaid with sheathing paper, plywood subflooring, and finished floor. The floor panels are usually room length $(10,12,14,16$, and $18 \mathrm{ft})$ by $4 \mathrm{ft}$ 0 in. wide, and are fastened to the joists by means of nailing strips resting against the sides of the joists.

Partition panels are similar to wall panels except that both faces are like the inside face of the wall panels.

Ceilings consist of precut joists and prefabricated ceiling panels of plywood. 'The ceiling panels are usually $8 \mathrm{ft} 0 \mathrm{in}$. wide and are fastened to the joists by nailing strips.

Roofs consist of precut rafters. plywood sheathing. and any suitable type of roofing. A typical section, having EA walls, is shown in figure 71 .

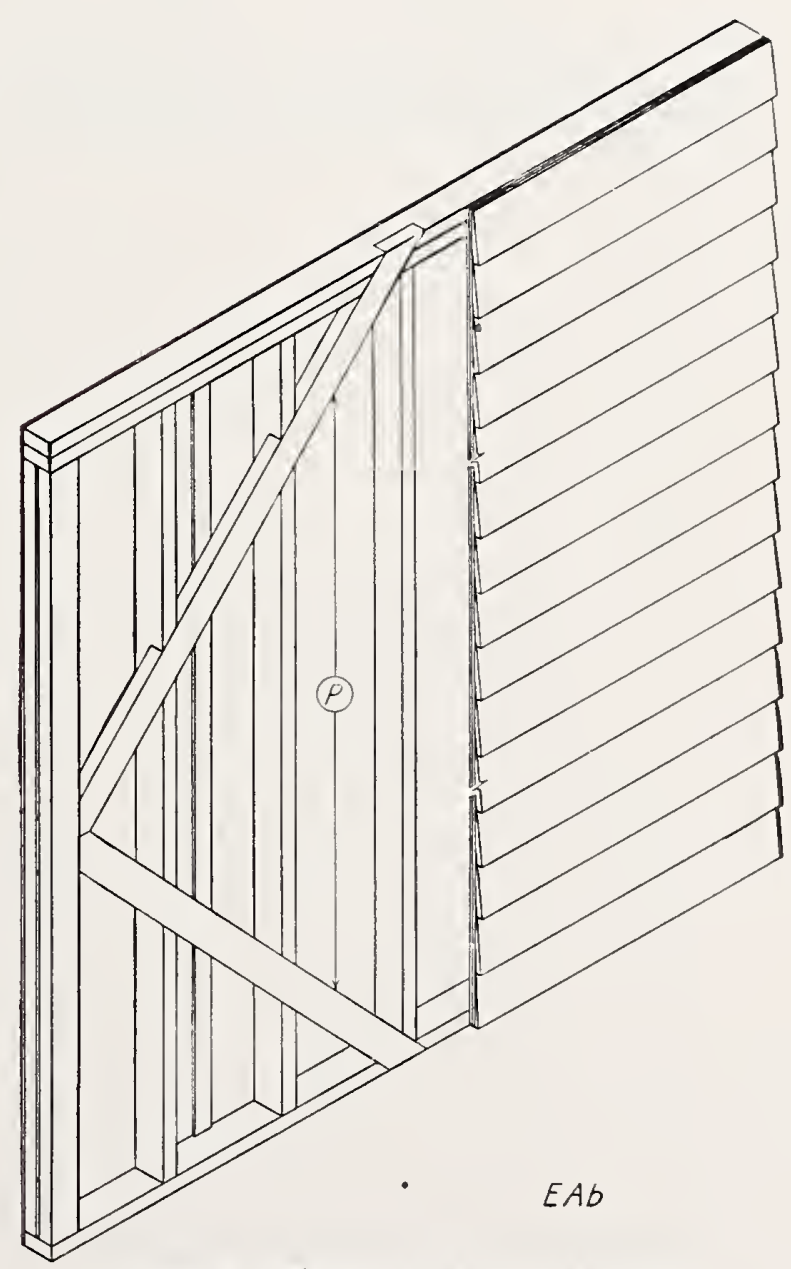

Figure 69.-Eight-foot wall specimen EAb. $P$, Diagonal brace. 


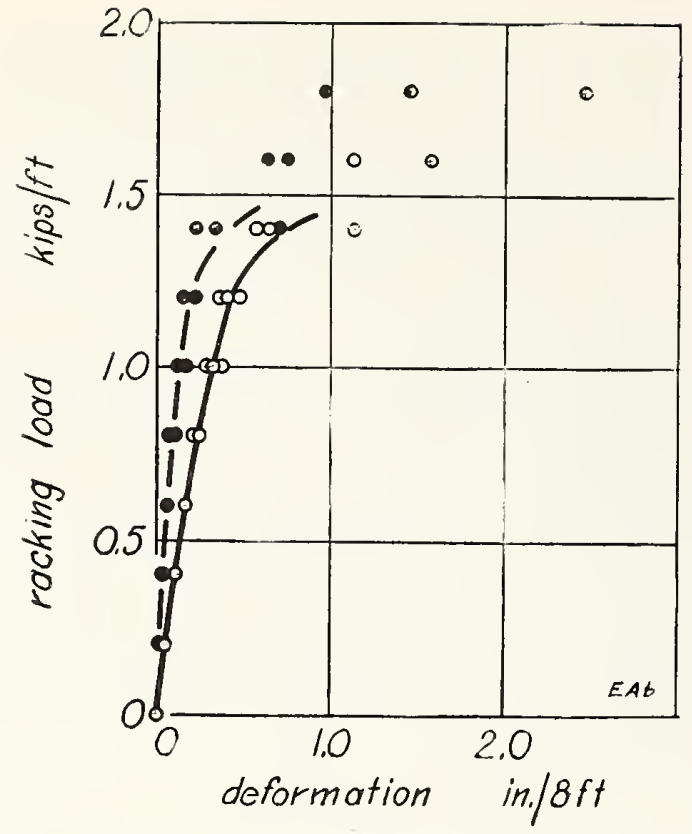

FIgURE 70.-Racking load on wall specimens EAb.

Load-deformation (open circles) and load-set (solid circles) results for specimens $E A b-R 1, R 2$, and $R 3$. The results are in kips per foot of actual width of specimen.

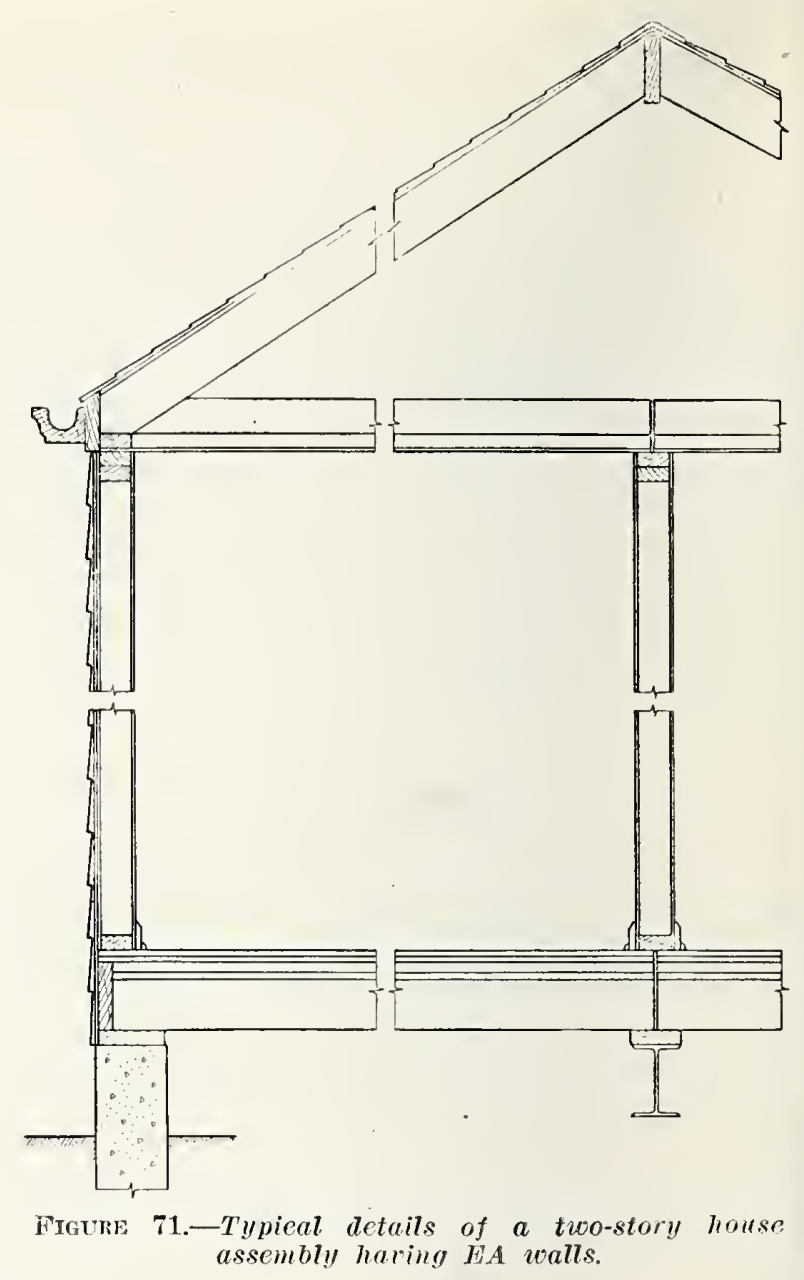

The descriptions and drawings were prepared by E. J. Schell and G. W. Shaw, of the Building Practices and Specifications Section, under the supervision of V. B. Phelan.

The structural properties were determined by the Engineering Mechanics Section, under the supervision of A. I. Stang, with the assistance of the following members of the professional staff: M. Greenspan, Richard W. Smith, and I. R. Sweetman.

Whimingon, June 6, 1944.

$$
\text { V.S. Government Printing Gffice : } 1945-659430
$$






\section{BUILDING MATERIALS AND STRUCTURES REPORTS}

\section{[Continued from cover page $\pi$ ]}

BMS32 Structural Properties of Two Brick-Concrete-Block Wall Constructions and a Concrete-

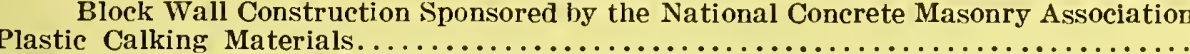

BMS33 BMS34

BMS35

BMS36

BMS37

BMS38

BMS39

BMS40

BMS41

BMS42

BMS43

BMS44

BMS45

BMS46

BMS47

BMS48

BMS49

BMS50

BMS51

BMS52

BMS53

BMS54

BMS55

BMS56

BMS57

BMS58

BMS59

BMS60

BMS61

BMS62

RMS63

BMS64

BMS65

BMS66

BMS67

BMS68

BMS69

BMS70

BMS71

BMS72

BMS73

BMS74

BMS75

BMS76

BMS77

BMS78

BMS79

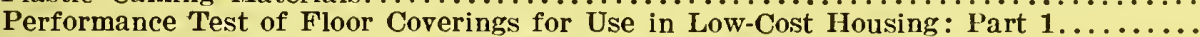

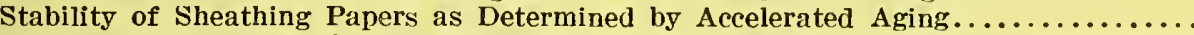
Structural Properties of Wood-Frame Wall, Partition, Floor, and Roof Constructions with "Red Stripe" Lath Sponsored by The Weston Paper and Manufacturing Co.

Structural Properties of "Palisade Homes" Constructions for Walls, Partitions, and

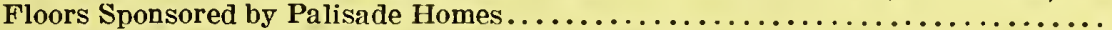

Structural Properties of Two "Dunstone" Wall Constructions Sponsored by the W. E.

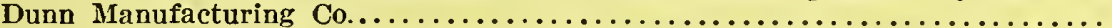

Structural Properties of a Wall Construction of "Pfeifer Units" Sponsored by the Wisconsin Units Co.

Structural Properties of a Wall Construction of "Knap Concrete Wall Units" Sponsored

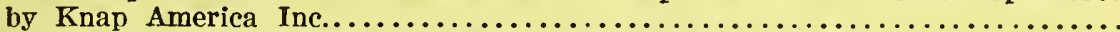

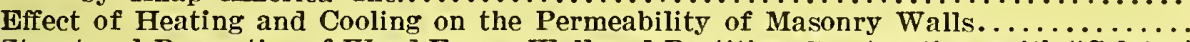
Structural Properties of Wood-Frame Wall and Partition Constructions with "Celotex" Insulating Boards Sponsored by The Celotex Cornoration. ................. Performance Test of Floor Coverings for Use in Low-Cost Housing: Part $2 \ldots \ldots \ldots \ldots$

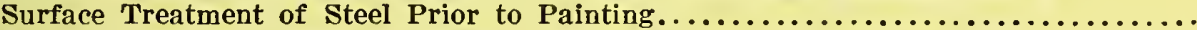

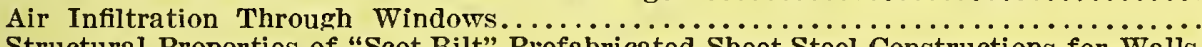
Structural Properties of "Scot-Bilt" Prefabricated Sheet-Steel Constructions for Walls,

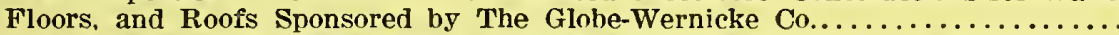
Structural Properties of Prefabricated Wood-Frame Constructions for Walls, Parti-

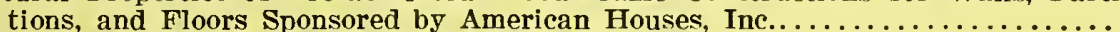
Structural Properties of "Precision-Built" Frame Wall and Partition Constructions

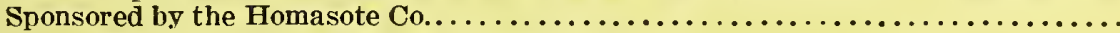

Metallic Roofing for Low-Cost House Construction. . . . . . . . . . . . . . . . . Stability of Fiber Building Boards as Determined by Accelerated Aging............ Structural Properties of "Tilecrete Type A" Floor Construction Sponsored by the

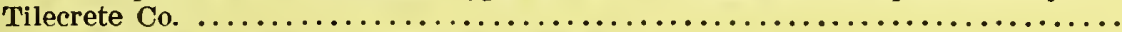

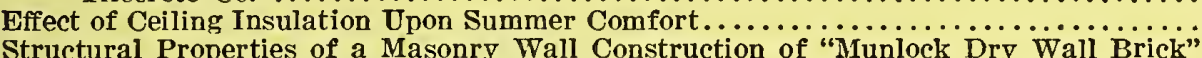

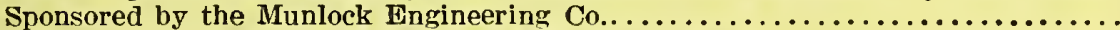
Effect of Soot on the Rating of an Oil-Fired Heating Boiler. $\ldots \ldots \ldots \ldots \ldots \ldots \ldots \ldots \ldots \ldots \ldots \ldots$ Effects of Wetting and Drying on the Permeability of Masonry Walls...............

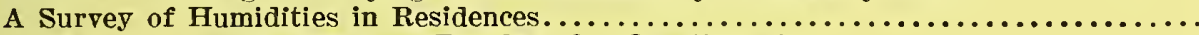
Roofing in the United States-Results of a Questionnaire....................

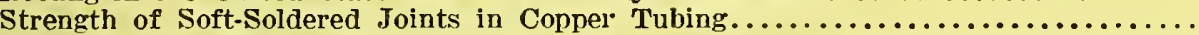

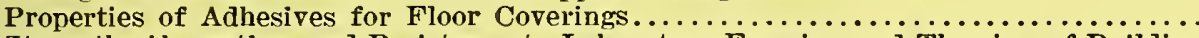
Strength, Absorption, and Resistance to Laboratory Freezing and Thawing of Building

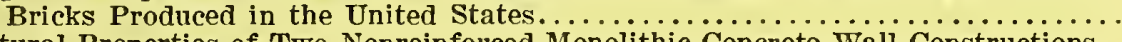

Structural Properties of Two Nonreinforced Monolithic Concrete Wall Constructions. . Structural Properties of a Precast Joist Concrete Floor Construction Sponsored by the

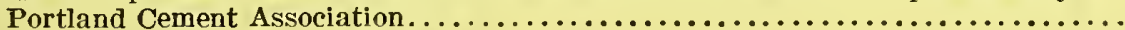

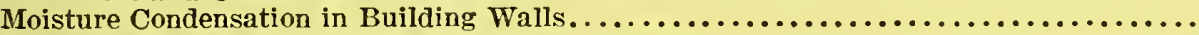

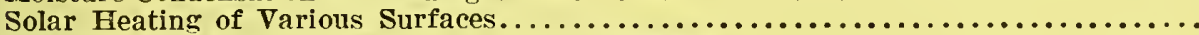

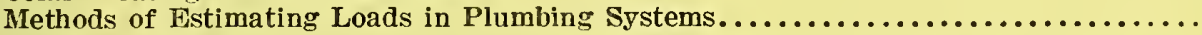

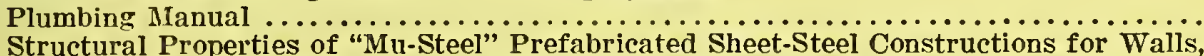
Partitions, Floors, and Roofs Sponsored by Herman A. Mugler ..............
Performance Test of Floor Coverings for Use in Low-Cost Housing: Part $3 \ldots \ldots \ldots$ Stability of Fiber Sheathing Boards as Determined by Accelerated Aging...........

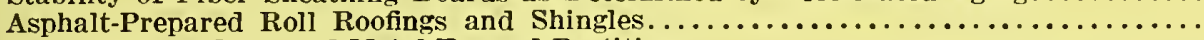

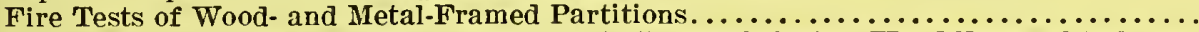
Structural Properties of "Precision-Built, Jr." Prefabricated Wood-Frame Wall Con-

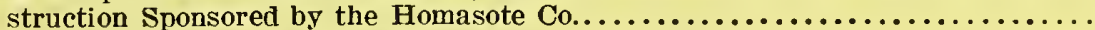

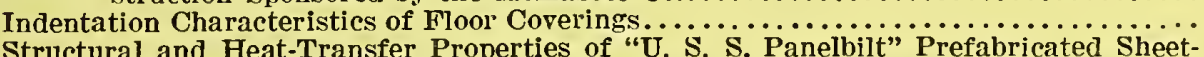
Structural and Heat-Transfer Properties of "U. S. S. Panelbilt" Prefabricated Sheet-
Steel Constructions for Walls, Partitions, and Roofs Sponsored by the Tennessee

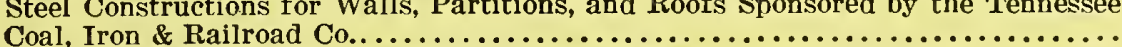

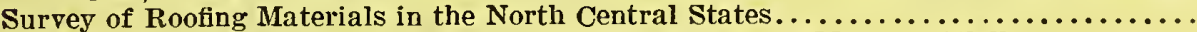
Effect of Outdoor Exposure on the Water Permeability of Masonry Walls............

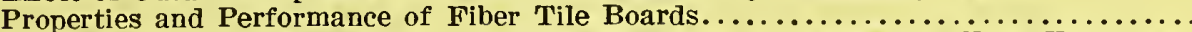
Structural, Heat-Transfer, and Water-Permeability Properties of Five Earth-Wall

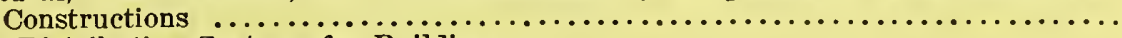

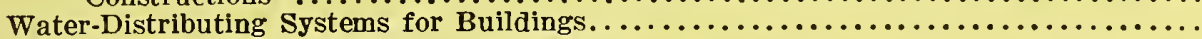

10 $15 \phi$ $10 \phi$ 104 104 104 $10 \%$ 104

Out of print. 
[Continued from cover page III]

BMS80 Performance Test of Floor Coverings for Use in Low-Cost Housing: Part 4.....

BMS81 Field Inspectors' Check List for Building Construction (cloth cover, 5 by $71 / 2$ inches)

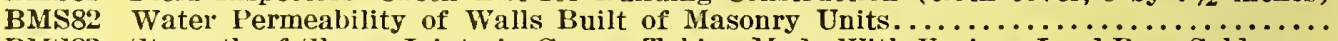

BMS83 Strength of Sleeve Joints in Copper Tubing Made With Various Lead-Base Solders...

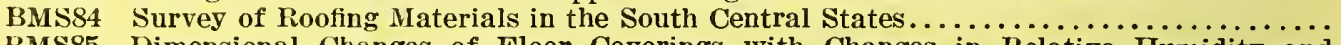

BMS85 Dimensional Changes of Floor Coverings with Changes in Relative Humidity and

BMS86 Structural, Heat-Transfer, and Water-Permeability Properties of "Speedbrik" W. Wali Construction Sponsored by the General Shale Products Corporation............

BMS87 A Method for Developing Specifications for Building Construction-Report of Subcommittee on Specifications of the Central Housing Committee on Research, Design,

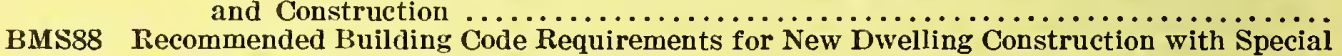

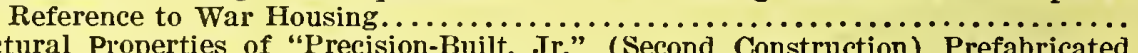

BMS89 Structural Properties of "Precision-Built, Jr." (Second Construction) Prefabricated Wood-Frame Wall Construction Sponsored by the Homasote Co...............

BMS90 Structural Properties of "PHC" Prefabricated Wood-Frame Constructions for Walls, Floors, and Roofs Sponsored by the PHC Housing Corporation.............

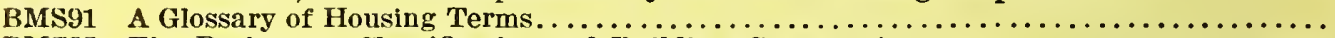

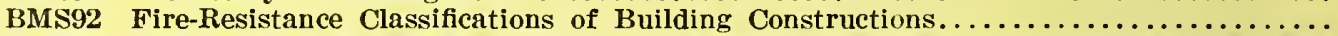

BMS93 Accumulation of Moisture in Walls of Frame Construction During Winter Exposure

BMS94 Water Permeability and Weathering Resistance of Stucco-Faced, Gunite-Faced, and

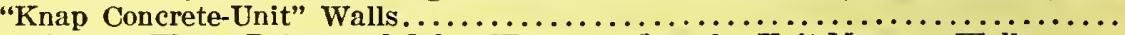

BMS95 Tests of Cement-Water Paints and Other Waterproofings for Unit-Masonry Walls......

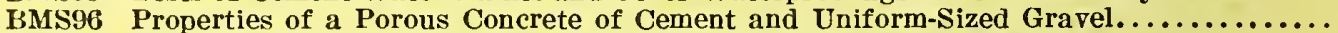

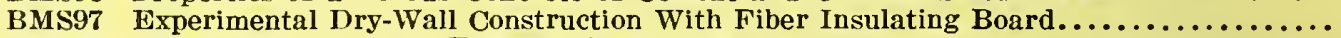

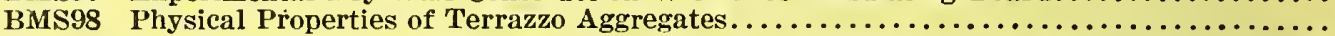

BMS99 Structural and Heat-Transfer Properties of "Multiple Box-Girder Plywood Panels"

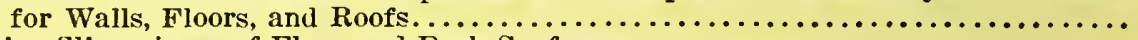

BMS100 Relative slipperiness of Floor and Deck Surfaces. $\ldots \ldots \ldots \ldots \ldots \ldots \ldots \ldots \ldots \ldots \ldots \ldots \ldots$

BMS101 Strength and Resistance to Corrosion of Ties for Cavity Walls.................

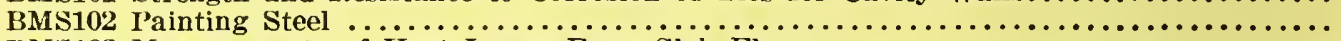

BMS103 Measurements of Heat Losses From Slab Floors. $\ldots \ldots \ldots \ldots \ldots \ldots \ldots \ldots \ldots \ldots \ldots$

BMS104 Structural Properties of Prefabricated Plywood Lightweight Constructions for Walls, Partitions, Floors, and Roofs Sponsored by the Douglas Fir Plywood Association

BMS105 Paint Manual: With Particular Reference to Federal Specifications (5 by $71 / 2$ inches, buckram bound) 